\title{
Essays on Digital Business Strategy Execution in the Financial Services Industry
}

Dissertation zur Erlangung des wirtschaftswissenschaftlichen Doktorgrades der Wirtschaftswissenschaftlichen Fakultät der Georg-August-Universität Göttingen 


\section{Betreuungsausschuss}

\section{Erstbetreuer}

Zweitbetreuer

Drittbetreuer
Prof. Dr. Jan Muntermann

Prof. Dr. Lutz M. Kolbe

Prof. Dr. Matthias Schumann 


\section{Danksagung}

Diese Dissertation wurde an der Professur für Electronic Finance und Digitale Märkte der Georg-August-Universität Göttingen geschrieben. Hiermit möchte ich mich bei meinem Betreuer Professor Jan Muntermann sehr bedanken, welcher während der Anfertigung dieser Dissertation immer ein offenes Ohr für mich hatte. Ohne sein konstruktives Feedback, Ratschläge und Unterstützung wäre diese Arbeit in der Form nicht möglich gewesen. Hierbei sind auch die Kontakte zu Praxispartnern zu nennen, bei denen ich mich an dieser Stelle ebenfalls bedanken möchte.

Ich danke auch meinen Betreuern, Professor Lutz Kolbe und Professor Schumann, welche stets sehr gute inhaltliche Anregungen gegeben haben und neue Sichtweisen zu weiteren Erkenntnissen führten.

Mein besonderer Dank geht an Professor Robert Wayne Gregory. Der Austausch und seine Unterstützung innerhalb unserer Zusammenarbeit hat die Anfertigung dieser Dissertation maßgeblich geprägt.

Einen nicht unerheblichen Einfluss bei der Erstellung dieser Arbeit haben auch meine Kollegen gehabt, die mich auf vielen der aufregenden Etappen meiner Promotion begleitet und stets für ein gutes Arbeitsklima gesorgt haben. Besonders zu nennen sind die zahlreichen inhaltlichen Diskussionen mit Matthias Eickhoff und Runhild Wieneke. Matthias Palmer hat mir in den letzten Zügen der Arbeit wertvolle Hinweise gegeben. Ich danke auch Griselda Sinanaj und Mirko Jan Zülch, Irina Alic, Jan Röder und Albert Torno.

Das Anfertigen einer Dissertation ist nicht immer ein geradliniger Prozess. Deshalb möchte ich ebenfalls meiner Familie für die Unterstützung und Motivation danken. Vor allem meine Frau, Ramona Weinrich, war immer für mich da und hat in vielerlei Hinsicht einen Einfluss auf den Abschluss dieser Arbeit gehabt. 



\section{Contents}

List of Figures .............................................................................................................. vi

List of Tables....................................................................................................................... vii

List of Acronyms .................................................................................................... viii

A. Foundations........................................................................................................ 1

1 Introduction and Motivation................................................................... 2

2 Research Questions................................................................................... 5

3 Positioning of the Thesis in IS.............................................................. 7

4 Structure of the Thesis.......................................................................... 11

4.1 Section A. Foundations ………………………………………... 11

4.2 Section B. Research Areas .......................................................... 12

4.3 Section C. Contributions ............................................................... 13

5 Research Background ............................................................................. 14

5.1 Theoretical Background .............................................................. 14

5.1.1 Digital Business Strategy ……………………………...... 14

5.1.2 Digital Business Models..................................................... 17

5.2 Financial Services Industry and Digitalization............................... 19

5.3 Research Methods ....................................................................... 21

5.3.1 Literature Review ............................................................. 21

5.3.2 Grounded Theory Methodology........................................ 22

5.3.3 Taxonomy Development .................................................... 24

5.4 Data Access and Collection............................................................ 25 
B.Research Areas ......................................................................................... 28

I. Digital Business Strategy Execution.......................................................... 29

I.1. Executing Digital Business Strategy: Organizational Design .................. 30

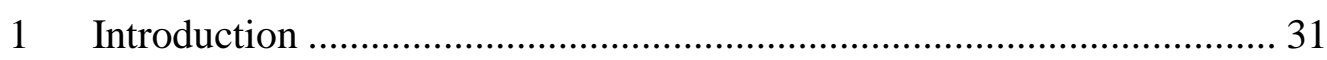

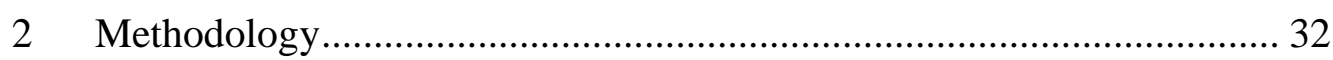

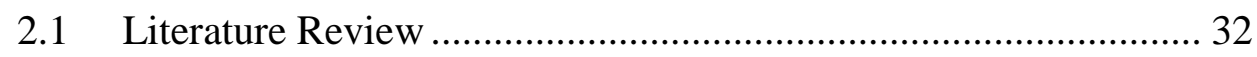

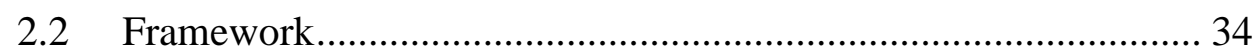

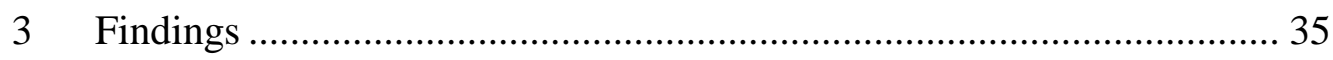

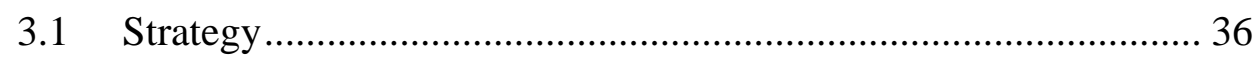

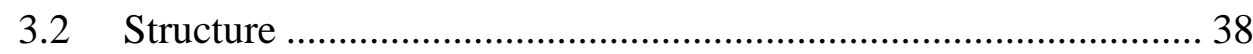

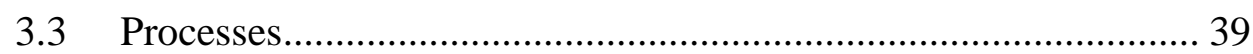

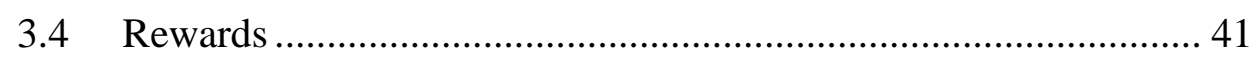

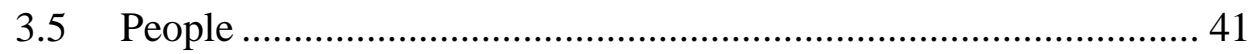

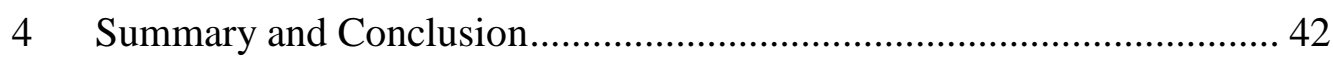

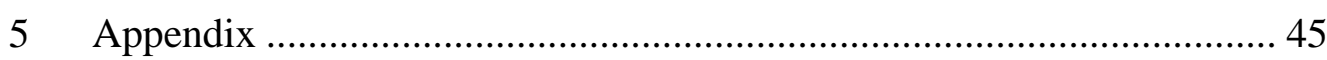

I.2. Executing Digital Business Strategy: Digital Platform .......................... 47

I.3. Executing Digital Business Strategy: Agile Approaches ........................... 49

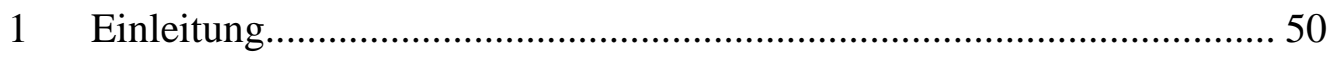

2 Relevante Grundlagen ............................................................... 51

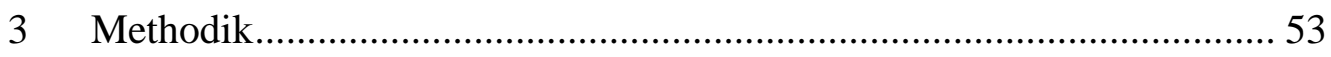

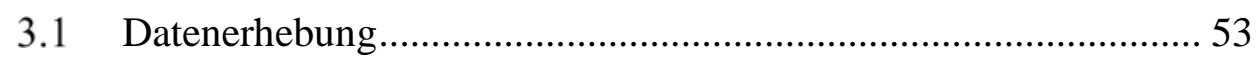

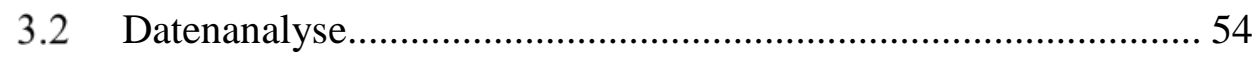

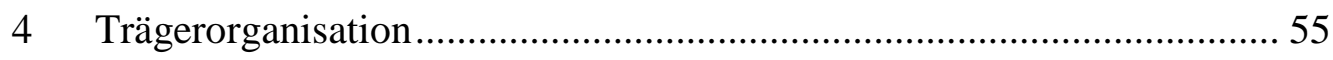

5 Ausgangssituation und Rahmenbedingungen....................................... 56

6 Herausforderungen für die Einführung agiler Vorgehensmodelle .......... 59

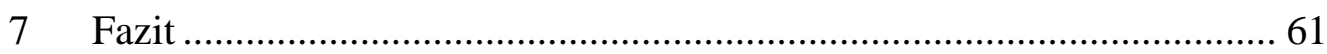




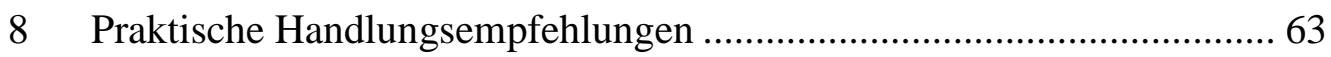

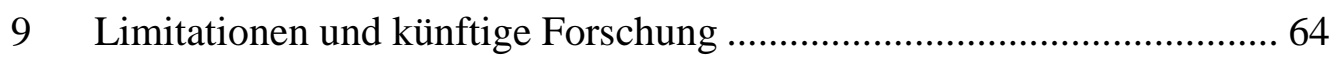

II. Digital Business Models ................................................................................6 65

II.1. Digital Business Models: FinTech Business Model Taxonomy ............. 66

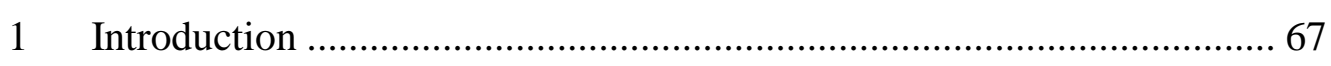

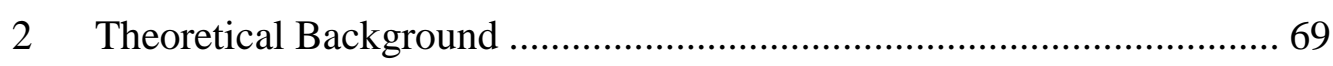

2.1 Classification Systems and Taxonomies .................................... 69

2.2 Conceptualizations of Business Models ...................................... 70

3 Methodological Approach to Taxonomy Development ......................... 72

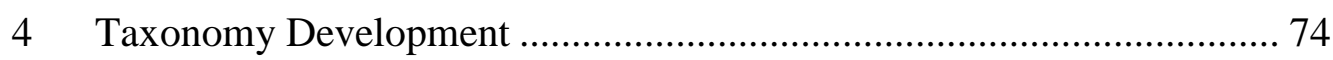

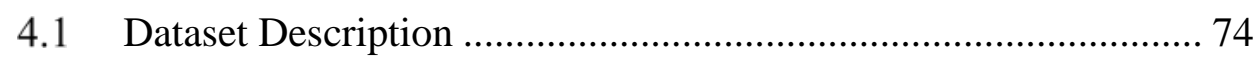

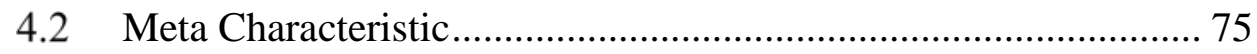

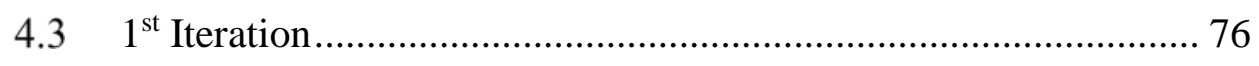

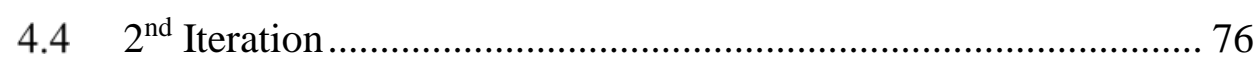

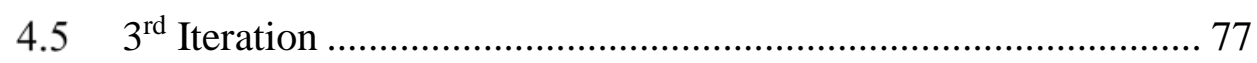

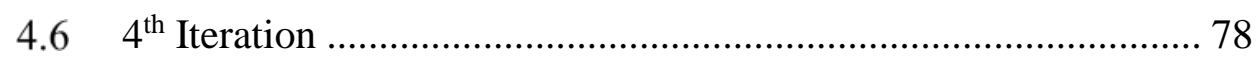

$5 \quad$ FinTech Business Model Taxonomy ................................................... 81

$6 \quad$ Archetypes of FinTech Business Models ............................................. 82

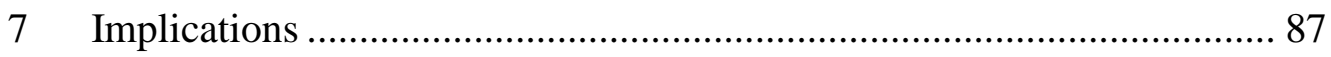

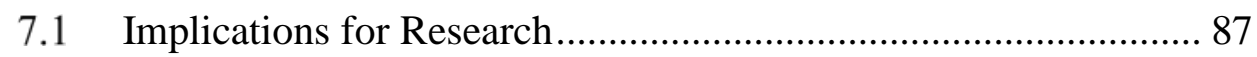

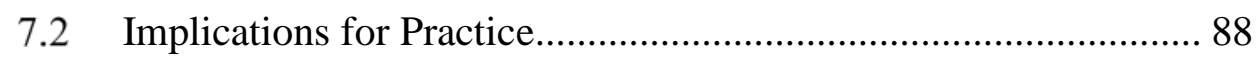

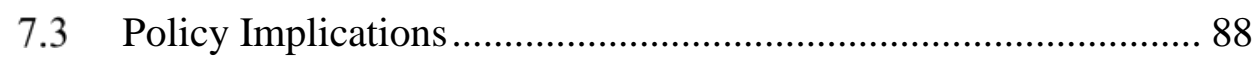

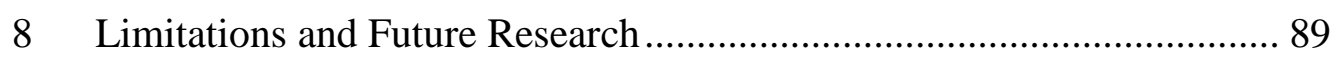

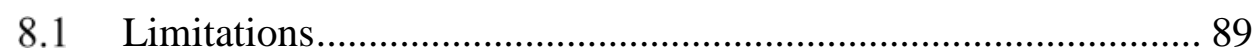

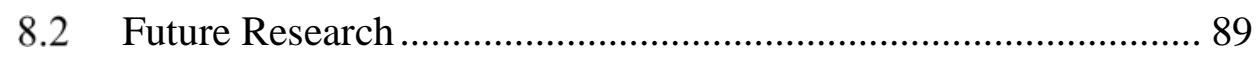

9 Appendix A: Description of Characteristics......................................... 91 


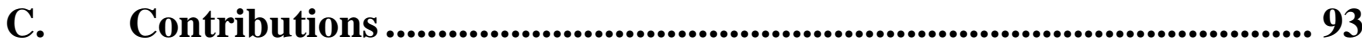

1 Summary and Synthesis of Findings .................................................. 94

1.1 Research Area I: Digital Business Strategy Execution ................. 94

1.2 Research Area II: Digital Business Models................................... 97

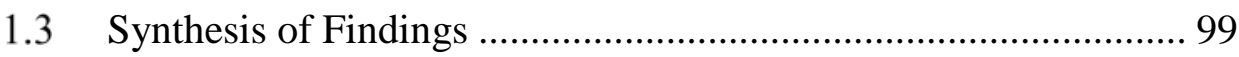

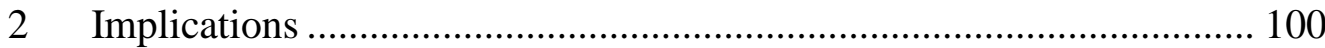

2.1 Research Area I: Digital Business Strategy Execution ............... 100

2.2 Research Area II: Digital Business Models................................. 103

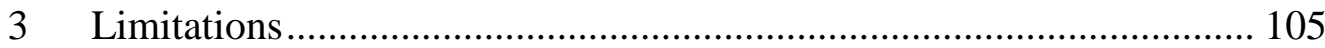

3.1 Research Area I: Digital Business Strategy Execution ............... 105

3.2 Research Area II: Digital Business Models............................... 106

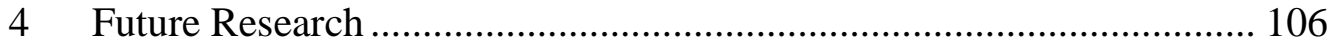

4.1 Research Area I: Digital Business Strategy Execution ............... 106

4.2 Research Area II: Digital Business Models............................... 107

References ...................................................................................................................... 109

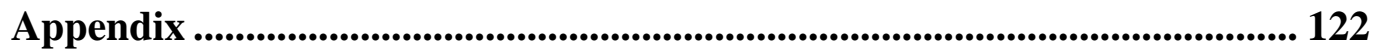




\section{List of Figures}

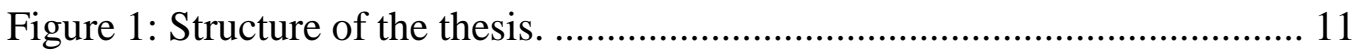

Figure 2: Cumulative articles published on DBS ............................................. 46

Figure 3: Taxonomy development method ….................................................. 73

Figure 4: Cluster dendrogram of firm tags as included in the Crunchbase ........ 84

Figure 5: Coding (three coder's consensus) of clusters ................................... 85

Figure 6: Connection between the research areas. .......................................... 99 


\section{List of Tables}

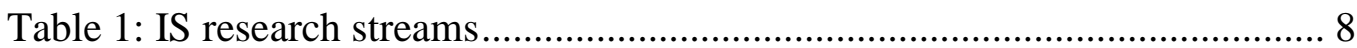

Table 2: Research papers in this thesis based on their research area ................. 13

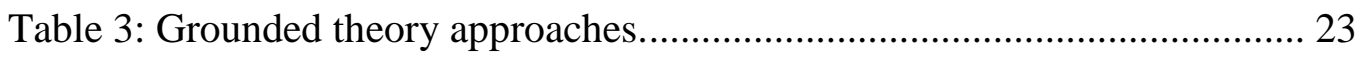

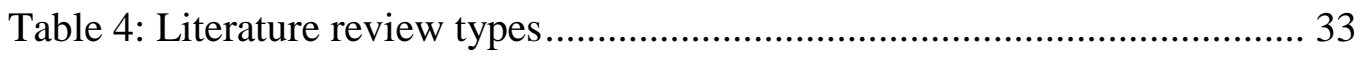

Table 5: Concept matrix of analyzed articles ................................................ 46

Table 6: Gegenüberstellung traditionelle und agile Softwareentwicklung ........ 52

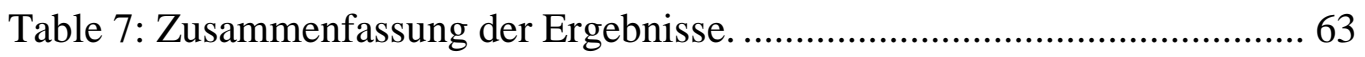

Table 8: Companies coded by country of origin. ............................................. 75

Table 9: Summary of the iterations and ending conditions............................... 80

Table 10: FinTech business model taxonomy................................................ 81

Table 11: Definitions of taxonomy dimensions. .............................................. 82

Table 12. FinTech business model archetypes ................................................ 86

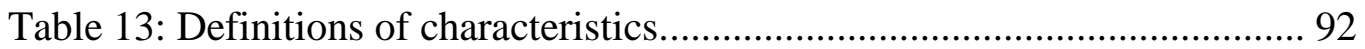




\section{List of Acronyms}

CDO. Chief Digital Officer

CEO Chief Executive Officer

CIO Chief Information Officer

DBS . Digital Business Strategy

GTM Grounded Theory Methodology

IS. Information Systems

IT ...Information Technology RQ. .Research Question 


\section{A. Foundations}

The first section, the foundations section, provides the necessary knowledge for the remainder of this thesis. It presents an introduction and statement of motivation followed by the research questions and the overall structure of this thesis. Finally, the research background, methods and data access and collection are shown. 


\section{Introduction and Motivation}

In the middle of the $20^{\text {th }}$ century, with the rise of the first programmable computer in 1941, information technology (IT) was successively introduced in a corporate environment. However, the emphasis was on back office support and efficiency gains, based on the technical process of digitizing, i.e., converting analogue content to a binary form (El Sawy et al. 2010; Tilson et al. 2010). During the last decade, remarkable advances in technology, especially miniaturization of devices, increasing (inter-)connectivity and steady improvements in the price-performance ratio of technology, unleashed new functionalities (Bharadwaj et al. 2013; Moore 1965). Ultimately, a paradigm shift of the role of IT towards ubiquity manifested with the introduction of the Apple iPhone in the consumer-goods market in 2007 as a strong example (Carr 2003; Ruch and Gregory 2014). IT became an integral part of our everyday life, highlighting a phenomenon known as digitalization, the sociotechnical impact of digital technologies that transforms entire industries and society at large (Tilson et al. 2010; Yoo 2010; Yoo et al. 2010). In this context, digital technologies are defined as combinations of information, computing, communication, and connectivity - with instantiations of e.g., social media, mobile devices, cloud computing, and the internet of things (Bharadwaj et al. 2013). Thus, the former IT function to primarily support companies with digital technologies gradually becomes a source of digital innovation enabling, for example, innovative products, services and processes for new opportunities for value creation and digital business models (Fichman et al. 2014; Kohli and Melville 2018). Notable examples of this strategic value shift include the companies Kickstarter (finance), Airbnb (hospitality), Uber (mobility), Spotify (music), and Amazon Kindle (books), all of which redefined entire markets and challenged incumbent companies. Therefore, being able to take full advantage of digital technologies and shape dynamic capabilities can help companies achieve a strategic advantage (El Sawy et al. 2010; Yoo et al. 2012). Consequently, the view on IT strategy, which was treated as a subordinate functional-level strategy that required alignment to a deliberate business strategy, is changing in research and practice. In this context, Bharadwaj et al. (2013) coined the term digital business strategy (DBS), which highlights the fusion between business strategy and IT strategy as an organizational strategy that makes use of digital resources for differential value creation. 
However, the emergence of digital technologies during the $21^{\text {st }}$ century has also translated into a turbulent environment for many companies. While almost all industries have begun to explore digital technologies, it remains a fundamental challenge for many incumbent companies to execute a corresponding DBS and transform their existing businesses for the digital age (Fitzgerald et al. 2014; Kane et al. 2015; Matt et al. 2015; Teece 2010). For example, Matt et al. (2015, p. 340) note “[...] DBS often describe desired future business opportunities and strategies for firms that are partly or fully based on digital technologies, they do typically not include transformational insights on how to reach these future states.”. Thus, there is a scarcity of knowledge on transformational insights, i.e., how a DBS is executed and achieved, referred to in this dissertation as DBS execution. This lack of understanding accounts for both research and practice (Hess et al. 2016; Matt et al. 2015).

Overall, the transformative impact of digitalization, rooted in digitization, particularly affects processes that require little physical interaction and products and services that are typically based on information. This is particularly true for many companies within the financial services industry (Puschmann 2017). For example, due to the commodity character of many financial products and services, we have witnessed an increase in cross-industry competition with technology companies such as Apple, Google or Amazon offering payment services. In addition, many financial technology startups have emerged, known as FinTechs, capturing market share with innovative business models in many segments of the financial services industry such as crowdfunding or peer-to-peer lending (Gomber et al. 2017). Next, the digital technology-induced change in customer behavior challenges traditional financial service business models, e.g., the branch business of retail banks. Thus, many financial service providers are rethinking their activities of how to create value including the relationship and channels towards their customers (Alt and Puschmann 2012; Setia et al. 2013). Finally, the financial crisis damaged the reputation of many financial service providers, and regulations such as MiFID II and EMIR had to be implemented, which translates into extra effort.

In sum, the use of digital technology is imperative to address many of these developments and financial service providers need to execute a corresponding DBS. Yet, there is still a lack of knowledge on DBS execution in general - particularly in the financial services industry. Therefore, this thesis positions itself at the intersection of the sociotechnical tensions including recent developments and characteristics of the 
financial services industry and DBS execution. To address this gap in our understanding, the aim of the thesis is twofold. First, it aims to contribute to the impact of digital technologies on a strategy level by analyzing the topic of DBS execution in the context of the financial services industry. Second, it aims to contribute to the impact of digital technologies at a business model level by analyzing innovative business models in the context of the financial services industry. By doing so, the thesis contributes to the organization science research streams of DBS, IT enabled business transformation and digital business models. Beyond that, the findings are also relevant to practice by addressing contemporary topics and highlighting possible solutions to problems that many companies face. 


\section{Research Questions}

To address the research gap stated in the introduction, this chapter contains the corresponding research questions (RQ) of the thesis. They are presented according two research areas of this thesis, I. Digital Business Strategy Execution and II. Digital Business Models.

The first research area I. Digital Business Strategy Execution, focuses on how companies execute a DBS. As mentioned, key environmental developments such as pervasive (inter-)connectivity, familiarity with IT, global supply chains, the emergence of big data including the abundance of information, an improved price/performance of IT and advances in cloud computing translate into a dynamic environment for incumbent companies. Confronted with these drivers and existing limitations of existing traditional business models, incumbent companies face the challenge of setting their DBS accordingly to adapt to the digital age (Bharadwaj et al. 2013; El Sawy et al. 2010). The first aim of this research area is to provide a general overview and understanding on DBS by analyzing how companies engage in DBS execution. Whereby execution of DBS can also be understood as adaptations in structures, processes, reward systems and people (Galbraith 1977; Kates and Galbraith 2010). The corresponding research question is as follows:

$R Q$ I.1. What is the state of knowledge on digital business strategy execution?

The second aim of this research area is to analyze DBS execution in the financial services industry. This is achieved by examining selected companies within the financial services industry. Accordingly, the second research questions is the following:

RQ I.2. How do financial service providers execute a digital business strategy?

The second research area II. Digital Business Models highlights the changing role of IT in the financial services industry. IT increasingly exceeds mere process automation and increased efficiency towards the role of enabling new digital business models (Fichman et al. 2014). In the context of the financial services industry, this topic is examined by the following two research questions:

RQ II.1: What dimensions and characteristics exist for digital business models in the financial services industry? 
RQ II.2: What are typical innovative digital business models in the financial services industry?

In sum, the first research question of the first research area highlights the state of the art of DBS execution in general, while the second research question of the first research area addresses DBS execution in the financial services industry. The second research area ant its research questions highlight a desirable outcome of DBS execution, i.e., towards digital business models. 


\section{Positioning of the Thesis in IS}

The following chapter briefly introduces typical IS research streams (Banker and Kauffman 2004) and epistemological perspectives of IS research (Orlikowski and Baroudi 1991) and positions this thesis in both.

Banker and Kauffman (2004) identify five major research streams in IS and describe them as follows i) decision support and design science: research on the application of computer decision support, control and managerial decision making; ii) value of information: research on relationships established based on economic analysis of information as a commodity in the management of an organization; iii) humancomputer system design, i.e., research on the cognitive basis for effectively designed systems; iv) IS organization and strategy: research with a level of analysis on individuals, groups and organizations and their behavior related to the management of IS and value of the IS investment; and v) economics of IS and IT: research on the application of theoretical viewpoints and methods from an analytical and empirical economics perspective to managerial problems that involve IS and IT. Table 1 summarizes the five research streams according to Banker and Kauffman (2004) and highlights their typical characteristics in terms of level of analysis, theories, methodologies used and related disciplines (next page). 


\begin{tabular}{|c|c|c|c|c|}
\hline $\begin{array}{l}\text { Research } \\
\text { stream }\end{array}$ & $\begin{array}{l}\text { Level of } \\
\text { analysis }\end{array}$ & Theories & Methodologies used & $\begin{array}{l}\text { Related } \\
\text { disciplines }\end{array}$ \\
\hline $\begin{array}{l}\text { Decision } \\
\text { support } \\
\text { and } \\
\text { design } \\
\text { science }\end{array}$ & $\begin{array}{l}\text { System level, } \\
\text { mostly in } \\
\text { conjunction with } \\
\text { human users or } \\
\text { business process, } \\
\text { up to the level of } \\
\text { a strategic } \\
\text { business unit }\end{array}$ & $\begin{array}{l}\text { Decision theory, } \\
\text { network } \\
\text { optimization, } \\
\text { control theory }\end{array}$ & $\begin{array}{l}\text { Mathematical } \\
\text { programming, } \\
\text { forecasting, } \\
\text { simulation, expert } \\
\text { systems }\end{array}$ & $\begin{array}{l}\text { Computer } \\
\text { science, } \\
\text { operations } \\
\text { research, } \\
\text { economics, } \\
\text { marketing, } \\
\text { strategic } \\
\text { management }\end{array}$ \\
\hline $\begin{array}{l}\text { Value of } \\
\text { informati } \\
\text { on }\end{array}$ & $\begin{array}{l}\text { Individual } \\
\text { decision makers, } \\
\text { technological in } \\
\text { business process } \\
\text { context, firm } \\
\text { actions in market } \\
\text { context }\end{array}$ & $\begin{array}{l}\text { Information } \\
\text { economics, real } \\
\text { options theory, } \\
\text { information } \\
\text { sharing theory }\end{array}$ & $\begin{array}{l}\text { Decision trees, } \\
\text { analytical models, } \\
\text { statistical analysis, } \\
\text { mathematical } \\
\text { programming, } \\
\text { simulation }\end{array}$ & $\begin{array}{l}\text { Economics, } \\
\text { decision } \\
\text { science, risk } \\
\text { management }\end{array}$ \\
\hline $\begin{array}{l}\text { Human- } \\
\text { computer } \\
\text { system } \\
\text { design }\end{array}$ & $\begin{array}{l}\text { User focused, } \\
\text { involving both } \\
\text { individuals and } \\
\text { groups }\end{array}$ & $\begin{array}{l}\text { Cognitive style, } \\
\text { behavioral } \\
\text { decision theory }\end{array}$ & $\begin{array}{l}\text { Experiments, } \\
\text { argumentation, } \\
\text { simulation, system } \\
\text { test-beds }\end{array}$ & $\begin{array}{l}\text { Cognitive } \\
\text { psychology, } \\
\text { decision } \\
\text { science, } \\
\text { design science }\end{array}$ \\
\hline $\begin{array}{l}\text { IS } \\
\text { organizat } \\
\text { ion and } \\
\text { strategy }\end{array}$ & $\begin{array}{l}\text { Spans levels: } \\
\text { individuals, } \\
\text { groups, business } \\
\text { units, } \\
\text { organizations, } \\
\text { marketplace }\end{array}$ & $\begin{array}{l}\text { Diffusion theory, } \\
\text { media richness } \\
\text { theory, resource- } \\
\text { based view of the } \\
\text { firm, transaction } \\
\text { cost economics, } \\
\text { task technology } \\
\text { fit, technology } \\
\text { acceptance model }\end{array}$ & $\begin{array}{l}\text { Models, case } \\
\text { studies, field studies, } \\
\text { experiments, } \\
\text { surveys, cross- } \\
\text { sectional and } \\
\text { longitudinal designs, } \\
\text { argumentation, } \\
\text { blend of qualitative } \\
\text { and quantitative } \\
\text { methods }\end{array}$ & $\begin{array}{l}\text { Organizationa } \\
\text { l theory, } \\
\text { strategic } \\
\text { management, } \\
\text { social } \\
\text { psychology, } \\
\text { cognitive } \\
\text { psychology, } \\
\text { economics }\end{array}$ \\
\hline $\begin{array}{l}\text { Economi } \\
\text { cS of IS } \\
\text { and IT }\end{array}$ & $\begin{array}{l}\text { Spans levels: } \\
\text { individual } \\
\text { decision makers, } \\
\text { business } \\
\text { process/product/ } \\
\text { project, strategic } \\
\text { business unit/ } \\
\text { firm, industry, } \\
\text { market, economy }\end{array}$ & $\begin{array}{l}\text { Theory of the } \\
\text { firm, production } \\
\text { economics, game } \\
\text { theory, contract } \\
\text { and incomplete } \\
\text { contracts theory, } \\
\text { network } \\
\text { externalities }\end{array}$ & $\begin{array}{l}\text { Analytical modeling, } \\
\text { empirical analysis } \\
\text { and econometrics, } \\
\text { cross-sectional and } \\
\text { longitudinal design, } \\
\text { experiments, } \\
\text { simulation }\end{array}$ & $\begin{array}{l}\text { Economics, } \\
\text { operations } \\
\text { research, } \\
\text { computer } \\
\text { science, } \\
\text { strategic } \\
\text { management }\end{array}$ \\
\hline
\end{tabular}

Table 1: IS research streams according to Banker and Kauffman (2004)

Regarding the research stream contribution, this thesis primarily contributes to i) decision support and design science and iv) IS organization and strategy. For i) the output of Gregory et al. (2017, paper II) provides prescriptive knowledge in the form of design principles and design product knowledge on designing a digital platform for multi-firm value co-creation as an instantiation of DBS execution. In addition, the paper of Eickhoff et al. (2017, paper IV) develops a FinTech taxonomy, which 
highlights conceptual knowledge in design science based on Iivari (2007). For iv), this thesis aims to understand the organizational behavior of how organizations execute a DBS towards digital business models. This in particular accounts for the literature review on organizational design for DBS execution in Weinrich (2017, paper I), and the introduction of agile methods for DBS execution in Weinrich et al. (2016b, paper III).

For the epistemological positioning of this thesis, an existing classification scheme for three central theoretical perspectives in IS research is used. It highlights i) positivist studies, ii) interpretive studies and iii) critical studies (Chua 1986; Orlikowski and Baroudi 1991). Overall, i) positivist studies assume a priori fixed relationships and usually aim to test theories to increase the predictive understanding of phenomena under investigation. Positivists take a passive role in the research process and view the social and physical world as objective - independently existent from humans. In contrast, ii) interpretive studies assume that people always interact with the world around them. Consequently, researchers view the reality and knowledge as social products and their assumptions, beliefs, values and interests always intervene and shape an analysis. In interpretive studies, researchers attempt to understand intersubjective meaning as part of social reality along with their cultural and contextual conditions. Ultimately, they try to explain the behavior of people and deeper structures of phenomena to inform other settings. Finally, iii) critical studies aim to evaluate and transform the social reality. In contrast, positivist and interpretive studies seek to predict and explain the status quo. Thus, the role of researchers may go beyond studying and theorizing towards actively changing the studied phenomena (Orlikowski and Baroudi 1991).

This thesis embraces the interpretive epistemology. It does not test existing theories (see positivist) but aims to explore and theorize on how incumbent financial services companies execute a DBS and the nature of FinTech business models. In the studies of Weinrich (2017, paper I), Gregory et al. (2017, paper II) and Weinrich et al. (2016b, paper III) the researchers interpret data that e.g., were primarily obtained via interview partners with their own subjective interpretation of reality (Walsham 1993). In addition, Gregory et al. (2017, paper II) and Weinrich et al. (2016b, paper III) make use of the grounded theory methodology (GTM) in which many researchers take in an interpretive epistemological view. The reason for this can be traced back to the nature of the GTM itself, which focuses on the development of a deeper understanding based 
on data - in contrast to other methods (Matavire and Brown 2013; Urquhart 2002). Finally, the exploratory nature of the studies Gregory et al. (2017, paper II) and Eickhoff et al. (2017, paper IV) and the process of how the conceptual and prescriptive design knowledge was obtained, also lends itself to the interpretive epistemology. 


\section{Structure of the Thesis}

This thesis is structured into three sections as shown in Figure 1: Structure of the thesis. First, Section A. Foundations contains an introduction with a statement of motivation, which is followed by the research questions and positioning of the thesis in IS. Second, Section B. Research Areas contains the individual research contribution of this cumulative dissertation. It is divided into the two major research areas of DBS execution and digital business models. Third, Section C. Contributions summarizes the individual findings and highlights the implications. In addition, it contains limitations and possible future research based on the presented contributions
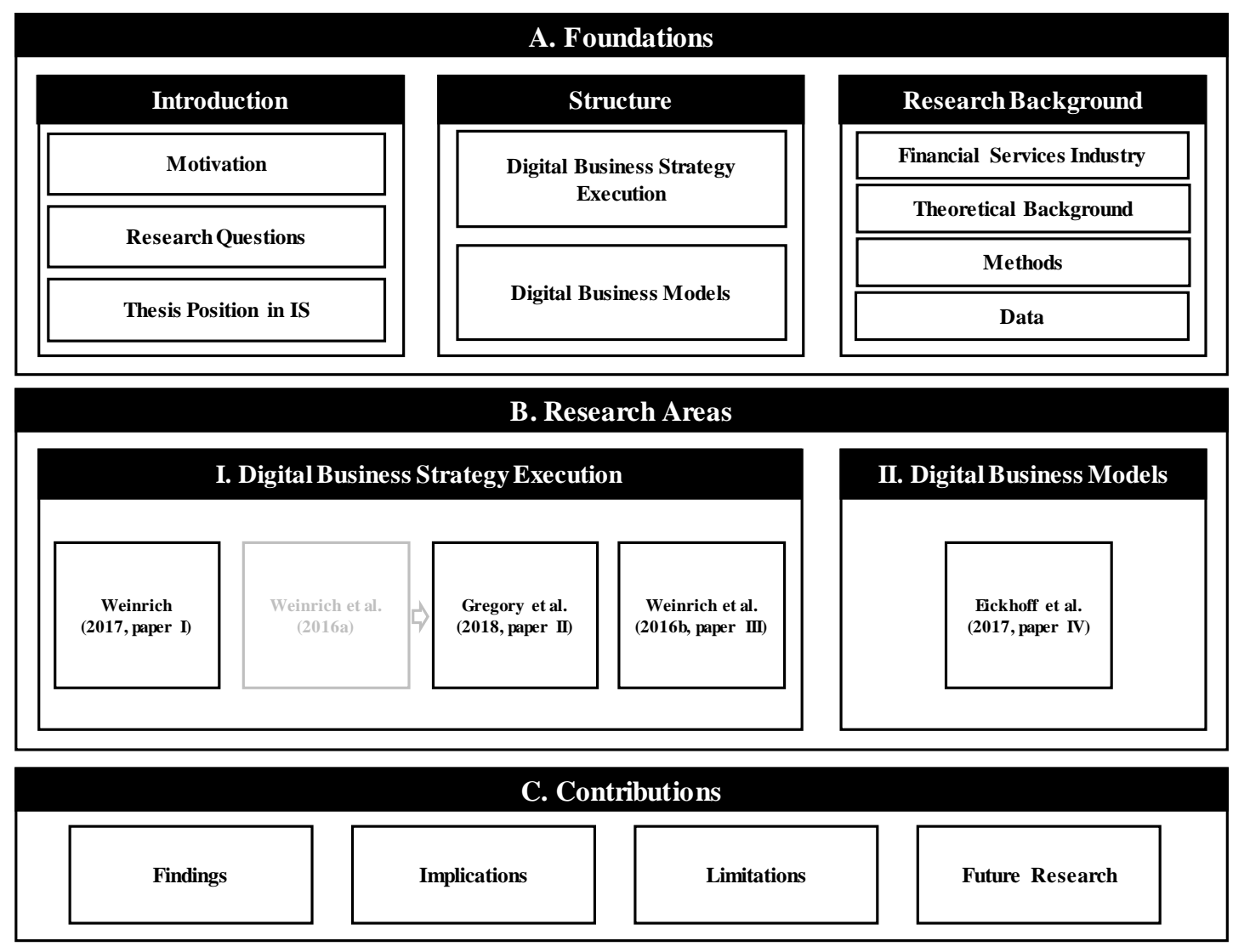

Figure 1: Structure of the thesis.

\subsection{Section A. Foundations}

As shown in Figure 1: Structure of the thesis, the foundations of the thesis consist of three parts. In the introduction, the motivation along with the research questions for this thesis are presented. Finally, a positioning of the thesis in the IS research streams and IS research epistemologies is conducted. The next part (this chapter) highlights the structure of the thesis. It is followed by a section on the research background, which provides a brief foundation of the knowledge necessary for understanding this thesis. 
Finally, the conducted research methods as well as data access and collection are presented.

\subsection{Section B. Research Areas}

There are two research areas in this thesis: i) the execution of DBS with a focus on incumbent financial companies and, ii) innovative entrepreneurial digital business models in the manifestation of FinTech archetypes (see also Figure 1: Structure of the thesis). Table 2 shows the individual research papers of this thesis according to their research area including the outlet and status as well as a brief description.

Research Area I. Digital Business Strategy Execution includes the research papers of Weinrich (2017, paper I), Gregory et al. (2017, paper II) and Weinrich et al. (2016b, paper III). First, Weinrich (2017, paper I) provides a literature review on DBS execution. As a strategy is inextricably linked to an organizational design, this paper explores organizational design components for DBS execution. Specifically, this paper sheds light on the organizational design components of strategy, structure, processes, rewards, and people. Gregory et al. (2017, paper II) and Weinrich et al. (2016b, paper III) shed light on DBS execution in the financial services sector by presenting two cases of financial service providers. First, Gregory et al. (2017, paper II) highlights a DBS execution of a company by showing the development of a digital platform along with the design choices that enable multi-firm value co-creation. Specifically, the paper theorizes on digital platform design principles (reliability-responsiveness, control-extensibility, standardization-variety). Moreover, an emergent design as a product design theory is presented. It highlights a both/and approach to combine IT efficiency and IT flexibility to enable multi-firm value co-creation. The final paper of the first research area is Weinrich et al. (2016b, paper III), which identifies challenges for an incumbent financial service provider to introduce agile development approaches for DBS execution.

Research Area II. Digital Business Models contains the research paper Eickhoff et al. (2017, paper IV). It addresses the current development of the FinTech phenomenon, where new entrants in the financial services industry emerge with innovative business models based on digital technologies. The contribution of this research paper is a FinTech business model taxonomy and the identification of FinTech business model archetypes. 
Research Area I. Digital Business Strategy Implementation

Paper

I. Weinrich (2017, paper I)

II. Gregory et al. Working Paper based on (2017, paper II) Weinrich et al. (2016a), Pacific Asia Conference on Information Systems 2016 (published).

\section{Outlet (Status)}

eBled 2017 (published)
III. Weinrich et al. (2016b, paper III)

\section{Contribution}

As digital business strategies are inextricably linked to organizational design, this explores organizational design components for DBS. Specifically, this paper sheds light on the organizational design components of strategy, structure, processes, rewards, and people.

Design as a product design theory along with the design principles (reliability-responsiveness, controlextensibility, standardizationvariety) that highlight a both/and approach to combining IT efficiency and IT flexibility to enable multifirm value co-creation. Ultimately, these socio-technical platform design choices enable multi-firm value co-creation of a company's DBS.

Identification of challenges for an incumbent financial service provider to introduce agile development methods for DBS execution.

\section{Research Area II. Digital Business Models}

\section{Paper}

I. Eickhoff et al. (2017, paper IV)

\section{Outlet (Status)}

International Conference on Information Systems 2017 (published)

\section{Contribution}

Development of a FinTech business model taxonomy and identification of FinTech business model archetypes.

Table 2: Research papers in this thesis based on their research area including the outlet and status as well as a brief description.

\subsection{Section C. Contributions}

The third section, C. Contributions. starts with a summary of the individual findings of each research paper in relation to the stated research question of the thesis. In addition, this section is also complemented by an integrative part that connects both research areas of this thesis. Next, the implications, limitations and future research possibilities are highlighted and discussed based on each contribution presented in section B. Research Areas. Figure 1: Structure of the thesis displays the structure of section C. Contributions. 


\section{$5 \quad$ Research Background}

\subsection{Theoretical Background}

\subsubsection{Digital Business Strategy}

A DBS can be defined as an "organizational strategy formulated and executed by leveraging digital resources to create differential value” (Bharadwaj et al. 2013, p. 472). A DBS moves beyond an enterprise strategy perspective with a dedicated IT and business strategy (Henderson and Venkatraman 1992) by fusing both of the respective strategies (Bharadwaj et al. 2013). An example is the case of the Development Bank of Singapore (Sia et al. 2016). In this case, a DBS is pursued to tackle new growth markets by leveraging digital platforms and mobile banking technologies towards building a new digital business model. The case highlights the fusion of IT within the business environment as a new condition for business strategy (Woodard et al. 2013). Accordingly, IT is now integral to the firm's business-level strategy of a firm, as opposed to a functional-level strategy (Drnevich and Croson 2013). This explains why the execution of a DBS of an incumbent firm often entails fundamental organizational transformation (Romanelli and Tushman 1994), as well as IT transformation (Gregory et al. 2015), whereby legacy corporate IT infrastructure is often morphed into a flexible digital platform. For example, in a case study of a U.K. bank, Kaniadakis and Constantinides (2014) found that the heterogeneity of legacy assets and the existing mortgage platforms of the bank were the main technical problems that had to be addressed to introduce mortgage securitization, which was addressed through IT transformation and platform innovation. The case study of another large European bank by Gregory et al. (2015) came to a similar conclusion: digital banking is enabled by building an integrated information infrastructure and platform for innovation by recombining existing and new IT components, including big data analytics software. These and other examples of strategic IT and organizational transformation highlight the critical role of corporate IT infrastructure in determining the platform for DBS, for example, by defining technical interfaces for customers, partners, and suppliers and by setting standards that determine the degrees of freedom for the formulation and execution of DBS (Keen and Williams 2013). Overall, DBS entails a very different scope, scale, speed, and sources of value creation and value capture compared to business strategies in the pre-digital era (Bharadwaj et al. 2013). 
First, the scope of DBS expands beyond the boundaries of a firm and involves the definition of a new role within the wider business ecosystem in which it operates (Priem et al. 2013; Selander et al. 2013). Keen and Williams (2013) argue that digital business is driven by the opportunities to expand value 'choice space'. For example, by empowering the buyer to determine which dimensions of value matter, leveraging ecosystem relationships rather than operating independently, and collaborating with entrepreneurs (e.g., FinTech startups) who are able to offer new dimensions of value compared to offerings of incumbents. In this regard, Bharadwaj et al. (2013) identified three key themes of DBS scope i) transcending functional areas, ii) digitization of products and services and iii) disruption of traditional supply chains towards ecosystems. Digital technologies directly affect controlled or owned products and services, businesses and activities of companies. They provide the connection between process and functional strategies and foster an internal information exchange within a company as well as external information exchange between companies. Thus, DBS transcends the functional areas and processes of a company that makes it more than just a strategy on a (cross-)functional level. Abundance of data becomes a crucial part of companies' DBS as they start to explore new technology-based product and service extensions. However, in an interconnected world, the creation and provision of products and services goes beyond company boundaries and tight supply chains. This implies that DBS includes dynamic and loosely coupled ecosystems comprising of its partners, alliances and even competitors across industries. An important a consequence is the consideration of how to standardize infrastructures and processes in a dynamic ecosystem.

Second, DBS are designed for scale, which is driven to a large extent through digital innovation (Huang et al. 2017). In particular, scaling through DBS and an underlying platform is achieved by building and provisioning standardized interfaces to developers on the platform, providing them with an abstracted vocabulary that enables application programmers to call up rich sets of the platform's functionality with simple commands (Boudreau 2012). The effect is one of democratization and the simplification of development, which ensures broad participation in platform-based digital innovation (Yoo et al. 2012; Yoo et al. 2010). Here, Bharadwaj et al. (2013) identified the four key themes for DSB scale i) up/down scaling capabilities, ii) network effects within multisided platforms, iii) conditions of information abundance and iv) alliances and partnerships. Scaling up/down via cloud computing represents 
the ability to adapt to the demand in dynamic market settings. Thus, it translates into a strategic, dynamic capability for many companies. In addition, as products and services become digitally (inter-)connected, one- and two-sided network effects increasingly occur and become a strategic advantage. Also the amount of data from various sources such as sensors and social media creates many opportunities for companies. Learning how to gain capabilities to make use of 'big data' may scale their strategic activity. Finally, DBS scaling increasingly occurs for business processes on a modular basis, where digital resources can easily be integrated and disintegrated from different actors. In such modular platform settings, alliances and collaborations form to share and leverage digital resources that complement each other to create value, which a company on its own would not be able to offer. An example would be startups that can easily draw on APIs of other actors.

Third, DBS entails greater speed, which includes significant acceleration of digital innovation and new product launches to flexibly adapt to quickly changing market conditions (Kotter 2014; Woodard et al. 2013). Speed in digital business is determined to a significant extent by the trait of reprogrammability of digital technology (Yoo 2010) and the possibilities for extensive recombination and reuse of IT components and digital resources (Boudreau 2012). This is afforded by the principles of modularity and decoupling application development from the underlying hardware (Lee and Berente 2012; Yoo 2010). In this regard, Bharadwaj et al. (2013) introduce the following key themes for DBS speed i) product launches, ii) decision making, iii) supply chain orchestration and iv) network formation and adaptation. As products increasingly have a digital component to a certain extent, steady improvements in price/performance and functionalities of information, communication and connectivity technologies also affect the speed of product launches. In addition, in today's world of business ecosystems, product launches regularly need to be harmonized across several actors that offer complementary products or services. In terms of decision making, increased access to data along with the capabilities to leverage it enables companies to make decisions more quickly. Therefore, they can react timely and adequately to changing customer demands, for example. For DBS, the speed of supply chain orchestration exceeds the management of a company's existing product portfolio towards dynamically managing suppliers and partners. Similarly, as the velocity of network formation and reformation increases, organizations need the capabilities to manage, design and structure networks, which provide complementary capabilities. 
Fourth, sources of value creation and value capture in DBS entail new dynamics that are associated with a move away from hierarchical integrated supply chains and a shift toward networks of strategic partnerships with diverse ecosystem participants (Pagani 2013). As part of this shift, customers increasingly create value for themselves and play a more important role in service creation and delivery (Setia et al. 2013), as do leveraging opportunities from big data and abundant digital resources (Bharadwaj et al. 2013; Woerner and Wixom 2015). Here, Bharadwaj et al. (2013) highlight the key themes i) increased value from information, ii) multisided business models, iii) coordinated business models in networks, and iv) value appropriation though control of architecture. Companies increasingly offer customized products and services based on customer preferences obtained via social media, for example. Therefore, DBS also captures new business models based on information. DBS also encompasses multisided business and multilayered business models, e.g., where companies give away a product or service on one layer and capture value at another layer, for example giving away free software but capture value through advertisement. In addition, the business models of many companies are embedded in a network setting to co-create and capture value. Finally, Bharadwaj et al. (2013) DBS sources of value creation and capture highlight value appropriation through control of whole digital industry architectures, which increasingly emerge.

\subsubsection{Digital Business Models}

While there is significant literature on business models, the definition and conception of business model is quite heterogeneous among researchers (Zott et al. 2011). In general, the business model concept helps in understanding the business logic of organizations by elaborating on value creation, delivery and capture (Osterwalder and Pigneur 2010). This thesis builds upon the notion of digital business models, in which the use of digital technology creates a fundamental shift in the value dimensions (Remane et al. 2017; Veit et al. 2014). The notion of an e-business model, in which organizations make use of information technology, can thereby be regarded as the predecessor of this view because it acknowledges technology as a source of value creation, delivery and capture (for a detailed review on different business model concepts see Zott et al. (2011)).

For e-business models, one of the most known contributions is Osterwalder et al. (2005, p. 12), who identify nine common business model elements: value proposition, target customer, distribution channel, relationship, value configuration, core 
competency, partner network, cost structure, and revenue model. Value propositions provide information on the products and services a company is offering. Target customer describes to whom the company intends to offer its products and services, i.e., the value; distribution channels are the means and ways of how a company reaches out to its customers; and relationship refers to the links a company creates between its target customers and itself. These three elements (target customer, distribution channel, and relationship) can also be subsumed under customer interface. Value configuration is how resources are arranged in relation to a company's activities; core competencies highlight the competencies that are needed to carry out the business model; and partner networks are the company's cooperation with other actors that are needed to create and offer the value. Value configuration, core competency and partner network can be categorized further as infrastructure management. Finally, the last two elements of a business model highlight financial aspects. The cost structure describes monetary consequences for a business model to operate, and the revenue model is the way the company receives money from its revenue streams (Osterwalder et al. 2005). While Osterwalder et al. (2005) does not explicitly refer to a technology component, Alt and Zimmermann (2001) present six common elements that an e-business models consist of: mission, structure, processes, revenues, legal issues, and technology. The mission is described as a crucial element of a business model. It encompasses an understanding ranging from corporate strategy down to products and services including the value proposition. In addition, a convincing business model is often led by a vision and not just by the technology behind it. Structure highlights the actors and governance a company is engaging, i.e., its value network. Furthermore, it also describes the company's geographic and industry focus. Processes can be viewed as a more granular look at a business model's mission and structure that provides detailed insight into the activities of value creation, i.e., customer orientation as well as coordination mechanisms. Revenues define the business' logic and sources of its revenue. Legal issues are an element that touches all dimensions. It potentially influences the vision, structure, value creation processes, and revenue model. Finally, technology can be an enabler of but also a constraint of a business model. Similar to legal issues, technological developments may influence the mission, structures, processes, and revenue model of a company.

Digital business models represent an emergent discipline; therefore, conceptualizations of digital business models are still scarce. A first attempt is 
conducted by El Sawy and Pereira (2013). The authors show that a digital business model specifically consists of the components value proposition, interfaces, service platforms, organizing model and revenue model. The revenue model highlights that in a digital business model both, revenues and costs, to be distributed among the participants of an ecosystem. In addition, a digital business model is usually embedded in an ecosystem and needs orchestration, which is described by the organizing model. Moreover, platforms as service delivery engines become increasingly popular. In this context, interfaces are the basis for interactions within ecosystems, platforms and customers. Finally, the framework also shows a value proposition component, which is an integral part of any traditional business model concept (El Sawy and Pereira 2013; Remane et al. 2017).

\subsection{Financial Services Industry and Digitalization}

As the digital revolution has been associated with remarkable breakthroughs in affordability, accessibility, and affordances of digital technology (Yoo 2010), it resulted in significant changes in industry standards and disruptions of incumbent business models (Pagani 2013). As mentioned in the introduction, this transformative impact of digitalization particularly affects the financial services industry because many products and services are based on information. Moreover, most processes require little physical interaction and are or can be fully digitized and automatized. For example, financial services such as payment transactions do not require any physical intervention (Puschmann 2017). Furthermore, many financial products and services can be characterized as commodities, i.e., there is little difference between versions or brands of the same product or service - in contrast to physical industries such as the automotive industry (Gopal 2014). During the past decade, several key developments impacted incumbent financial service providers in particular i) change in the role of IT, ii) new ways of value creation and capture, iii) changing customer demand, and iv) regulation (Puschmann 2017). i) The ongoing improvements in price/performance of information technology as well as new functionalities and its convergence exceed merely the automation of business processes and efficiency gains. Digital technologies such as social media, big data, cloud computing and mobile in particular computing provide new ways of value creation for financial service providers such as innovative processes, products, services or even business models (Bharadwaj et al. 2013; Puschmann 2017). Combined with the commodity character of many financial products and services, we also witnessed an increase in cross-industry competition 
with technology companies such as Apple, Google or Amazon, which are offering traditional services like payment services or even whole new business models. ii) Companies with such new business models are also known as FinTechs - "a new generation of financial technology startups that are revolutionizing the financial industry” (Sia et al. 2016, p. 105). The emergence of FinTechs provides a strong indication that the financial services industry has already started to undergo a digital transformation, which has given rise to DBS. Having been introduced approximately within the last decade and driven by digital innovation (Arner et al. 2015; Lee and Teo 2015), FinTech has been portrayed as a phenomenon of entrepreneurs who strive to 'change the rules of the game' across a growing variety of financial services domains, particularly by leveraging digital resources for the purpose of offering improved service and experience to customers at a lower cost (Mackenzie 2015). An example of this phenomenon is the rise of crowdfunding platforms, which connect supply and demand with greater efficiency, yet also provide a better customer experience compared to traditional financial intermediaries (Haas et al. 2014). In this regard, mobile payment technology innovations offer another interesting example. A key study in this area suggests the emergence of technology ecosystems that span different layers of digital m-payments technology, including digital platforms (e.g., mobile and/or online banking, location-based services), services (e.g., cloud-based mpayment services), and artifacts or components (e.g., credit and/or debit cards, NFCenabled smartphones) (Liu et al. 2015). These and other examples highlight the emergent focus on scalability for cases in which the average revenue per user is low, yet paired with a high critical mass of customers (Lee and Teo 2015). iii) In sum, FinTechs are able to overcome the very digital shortcoming of incumbents in many segments of the financial services industry (Gomber et al. 2017) and address changing customer demands, which are characterized as technology savvy that increasingly make use of digital channels to satisfy their demand for financial products and services. The availability and accessibility of products and services are expected to be anywhere and anytime in a transparent manner (Dapp et al. 2014). This digital technologyinduced change in customer behavior challenges traditional financial service business models such as the branch business of retail banks. Thus, many financial service providers need to rethink their activities of how to propose value along with the relationship and channel towards their customers (Alt and Puschmann 2012; Setia et al. 2013). iv) Additionally, the financial crisis damaged the reputation of many financial service providers and brought new regulations. At the same time, despite 
regulatory hurdles, or more precisely because regulation has not yet been able to fully adapt to the fast-paced changes in digital technology and market conditions, the financial services industry is now also undergoing digital transformation (Lucas Jr et al. 2013). In particular, new regulations affect the financial service sector by constraining incumbents' actions (such as the increased capital requirements of Basel III), while concurrently enabling new financial technology business models (Gomber 2016).

Due to the large scope of the financial services industry (cf. for example, Standard Industrial Classification or Industry Classification Benchmark), this thesis particularly focuses on the two financial service providers presented in Gregory et al. (2017, paper II), a business-to-business financial data brokerage and services provider, and an asset management company in Weinrich et al. (2016b, paper III)

\subsection{Research Methods}

This section provides a general overview of the main methods that are used within the studies of this thesis. For detailed information about the applied methods in each paper, please refer to the corresponding study of this dissertation.

\subsubsection{Literature Review}

Literature reviews intend to manage the progress of prior studies of a given research stream. By aggregating and analyzing existing studies, they can provide an orientation of knowledge and help to uncover what is known and what is not known. Consequently, an identification of research gaps is possible, and future research directions can be highlighted. In sum, literature reviews are a useful and meaningful tool at the beginning of any research (Paré et al. 2015; Webster and Watson 2002). However, over time, many different suggestions on how to conduct a literature review in IS emerged (e.g., Fettke 2006; Levy and Ellis 2006; Webster and Watson 2002) along with methodical variations (e.g., Wolfswinkel et al. 2013). Thus, an extensive range of different literature review types exist (Templier and Paré 2015). Paré et al. (2015) analyzed this diversity and put forth a typology of literature review types in IS (see Table 4: Literature review types in this dissertation in the study of Weinrich (2017, paper I), for more information on the typology).

In this thesis, the study of Weinrich (2017, paper I) conducts a literature review on organizational design in the context of DBS execution. It follows the instructions of Webster and Watson (2002) including the major steps of a keyword search: a backward 
search and a forward search. In the light of literature review types proposed by Paré et al. (2015), Weinrich (2017, paper I) can be categorized as a descriptive review. It summarizes the prior knowledge based on a rather broad research question with a given framework and predefined selection criteria. The search process is comprehensive, and, due to the relatively young phenomenon of DBS, the identified literature is of conceptual and empirical nature.

\subsubsection{Grounded Theory Methodology}

With over 50 years of tradition, GTM has its origin in the social sciences and can be traced back to the works of Glaser and Strauss (1965); Glaser et al. (1968). However, as Strauss and Corbin (1990) published a work on GTM, a separation of the methodology manifested. In Glaser's (1992) opinion this work was not in line with the original meaning of GTM (Glaser and Strauss 1965; Glaser et al. 1968), but is rather a "full conceptual description" (p. 123). It started an ongoing discussion between Glaser and Strauss and, over time, two different approaches to GTM emerged, the 'Glaserian grounded theory' and 'Straussian grounded theory' (Heath and Cowley 2004).

However, either GTM approach has some general characteristics in common as Urquhart et al. (2010) note. The main purpose of GTM is to systematically build (or enhance) a theory of human behavior - not theory verification- derived from data. The researchers may enter data collection with a general understanding of the domain, i.e., theoretical sensitivity, but without a preformulated hypothesis. Furthermore, it is crucial that the processes of data collection, coding and analysis are done in parallel. Newly collected data should allow for new insights, which in turn may reshape previously coded and analyzed data based on this joint collection of data and constant comparison. Additional data slices are collected based on theoretical sampling, which depends on the emerging theory and the core category -until saturation is achieved, i.e., new data only lead to marginal added value.

In established research streams, GTM might not be as powerful as it could be as a method, mostly due to a lack of emergence of new categories and concepts (Glaser 1992) - unlike IS as an evolving discipline. Especially with the recent impact of digitalization (including the topic of this dissertation on DBS execution) GTM is a valuable methodology. In particular, the flexible nature of GTM has proven to be very useful for research on socio-technical phenomena in IS (cf. Urquhart 2007; Urquhart 2012) and addresses the frequent call to generate theories in IS (Urquhart et al. 2010). 
Consequently, GTM is becoming more and more established in IS research (Wiesche et al. 2017). The increasing acceptance and adoption of GTM in IS has led to four major approaches of how GTM is used in IS: i) classic grounded theory approach, ii) evolved grounded theory approach, iii) grounded theory approach as part of a mixed methodology, and iv) use of grounded theory techniques -the most common approach in IS research- which is used for data analysis in particular. The four approaches are further described below in Table 3: Grounded theory approaches Matavire and Brown (2013, p. 124):

\begin{tabular}{|c|c|c|c|c|c|}
\hline Approach & GTM & Coding & $\begin{array}{l}\text { A priori } \\
\text { theory }\end{array}$ & $\begin{array}{l}\text { Paradigm } \\
\text { model }\end{array}$ & $\begin{array}{l}\text { Typical } \\
\text { references }\end{array}$ \\
\hline Classic & Required & $\begin{array}{l}\text { Open, } \\
\text { Selective, } \\
\text { Theoretical }\end{array}$ & $\begin{array}{l}\text { Should not } \\
\text { be used }\end{array}$ & $\begin{array}{l}\text { Viewed as one } \\
\text { of a family of } \\
18 \text { theoretical } \\
\text { codes }\end{array}$ & $\begin{array}{l}\text { Glaser et al. } \\
\text { (1968), } \\
\text { Glaser (1992), } \\
\text { and other works } \\
\text { authored by } \\
\text { Glaser }\end{array}$ \\
\hline Evolved & $\begin{array}{l}\text { Required } \\
\text { (Glaser } \\
\text { disputes } \\
\text { adherence) }\end{array}$ & $\begin{array}{l}\text { Open, Axial, } \\
\text { Selective } \\
\text { coding for } \\
\text { process }\end{array}$ & $\begin{array}{l}\text { May be } \\
\text { used as a } \\
\text { sensitizing } \\
\text { device }\end{array}$ & Recommended & $\begin{array}{l}\text { Strauss and } \\
\text { Corbin (1990), } \\
\text { Corbin and } \\
\text { Strauss (1998) }\end{array}$ \\
\hline Analytical & $\begin{array}{l}\text { Not } \\
\text { necessarily }\end{array}$ & $\begin{array}{l}\text { Any or all } \\
\text { used }\end{array}$ & Often used & $\begin{array}{l}\text { Sometimes } \\
\text { used }\end{array}$ & $\begin{array}{l}\text { Variety, but } \\
\text { often Strauss' }\end{array}$ \\
\hline $\begin{array}{l}\text { Mixed } \\
\text { Method }\end{array}$ & $\begin{array}{l}\text { Not } \\
\text { necessarily }\end{array}$ & $\begin{array}{l}\text { Any or all } \\
\text { used }\end{array}$ & $\begin{array}{l}\text { Mixed } \\
\text { method }\end{array}$ & $\begin{array}{l}\text { Sometimes } \\
\text { used }\end{array}$ & $\begin{array}{l}\text { Mingers (2001), } \\
\text { Baskerville and } \\
\text { Pries-Heje } \\
\text { (1999) } \\
\text { or any other } \\
\text { work claiming of } \\
\text { a grounded } \\
\text { theory derived } \\
\text { methodology. }\end{array}$ \\
\hline
\end{tabular}

Table 3: Grounded theory approaches.

For excellent GTM research in IS, Birks et al. (2013) outline six key criteria that have been identified by IS GTM leaders: i) theoretical development, according to rich description and the systematic exploration of key accounts, are related to the phenomenon of study (through interviews, observations, and possibly other methods and data sources) and provide the basis for developing rather than testing theory, ii) constant comparison, that is, analyzing data from different perspectives and viewpoints (through sense-making techniques such as analytical and theoretical memos that are crafted as transitional steps from raw data to emerging theory), iii) 
iterative coding, by which concepts, their dimensions, and theoretical relationships are defined (through coding techniques such as open, selective, and theoretical coding), iv) theoretical sampling, where the researcher systematically collects and analyzes data by determining the analytical grounds from which to sample and the additional data slices to collect to saturate emerging concepts and the relationships between them, v) the management of preconceptions, which is critical to ensure that a study is not driven by existing theories and paves the way for the generation of relevant theories that pertain to the phenomenon that is under study (through techniques such as treating a prior theory of the phenomenon as data to be compared against substantive evidence that is gathered through field study), and vi) an inextricable link between data collection and analysis, according to which data collection and analysis are performed in a recursive manner and more or less at the same time.

Concerning this thesis, the exploratory and theoretical nature of a timely yet poorly understood phenomenon of DBS execution within the financial services sector of the studies Gregory et al. (2017, paper II) and Weinrich et al. (2016b, paper III) lends itself to the choice of GTM. The studies satisfy the major steps outlined by Birks et al. (2013) above. Positioning the studies in table 3 above by Matavire and Brown (2013), Gregory et al. (2017, paper II) can be describes as a mixed method approach. The study draws on the design science paradigm to extract a set of design principles that highlight a both/and approach to combining IT efficiency and IT flexibility to enable multi-firm value co-creation. It examines the transformation of an IT architecture into a digital platform that achieves this synthesis between IT efficiency and IT flexibility by incorporating a set of design principles. Ultimately, it yields a design theory for digital platforms that enables value co-creation. Thus, research process and output are a mix of GTM and design science research. The study of Weinrich et al. (2016b, paper III) draws from GTM coding techniques and data analysis to conceptualize the emerging challenges for agile methods for DBS execution. Therefore, this study is most in line with the analytical approach of GTM.

\subsubsection{Taxonomy Development}

Possibly the earliest and a well-known classification system traces back to Carl Linnaeus, a botanist, physician, and zoologist who published "Systema Naturae" in 1758. It highlights a comprehensive classification of species of animals and plants (Linnæus 1735). In general, a classification system puts structure to a field of knowledge and can help researchers to hypothesize about the relationships among 
classified objects. They prove to be especially useful to e.g., explain differences and similarities of objects, as well as uncovering and classifying non-existent objects (Glass and Vessey 1995; Varshney et al. 2015). The need for ordering or classification of objects and phenomena of interest has been recognized as a fundamental form of science in most scientific disciplines, as it aims to organize concepts of knowledge (Carper and Snizek 1980). In this regard, taxonomies are a classification form for organizing existing knowledge (Wand et al. 1995), which also represents an ongoing subject in IS (Hirschheim et al. 1995). Moreover, they allow for theory building, which is also an important to objective to the IS community (Varshney et al. 2015).

In this thesis, Eickhoff et al. (2017, paper IV) develop a taxonomy of FinTech business models based on a method for taxonomy development proposed by Nickerson et al. (2013). At the beginning of the taxonomy development process the meta characteristic, on which all dimensions and characteristics are based, is determined. The taxonomy development process ends when predefined subjective and objective ending criteria are met e.g., no new taxonomy dimensions or characteristics are discovered. The development itself occurs in an iterative manner, by using conceptual-to-empirical and empirical-to-conceptual approaches to identify possible new dimensions and characteristics. For a more detailed view on taxonomy development please refer to Nickerson et al. (2013) or Eickhoff et al. (2017, paper IV) in this thesis.

\subsection{Data Access and Collection}

This section provides a brief overview of the available data that were used for each paper of the thesis. It is presented chronologically by the order of studies within this dissertation. For detailed information on the data selection process and analysis, please refer to the corresponding paper within this dissertation.

The study of Weinrich (2017, paper I) is a state of the art review on DBS and organizational design. Thus, its data are existing research studies that are relevant to the topic. The initial keyword search for the topic relevant literature is conducted by drawing on 50 major IS journals and 16 IS conferences as proposed by Levy and Ellis (2006, p. 186). It is complemented by the Financial Times 50 journals (FinancialTimes 2017). In doing so, the scope of the search covers the dual aspects of DBS and organizational design for this study, i.e., management literature on the one hand and IS literature on the other hand. Following Webster and Watson (2002), three major steps to conduct this literature review are conducted: i) a keyword search, ii) a 
backward search, and iii) a forward search, which resulted in a final sample of 39 relevant articles.

Gregory et al. (2017, paper II) construct a nascent design theory on building a digital platform for value co-creation in a multi-actor setting. The data for the study were obtained in a case of a strategic IT transformation program at a business-to-business financial data brokerage and services provider that transformed its IT architecture into a digital platform for multi-firm value co-creation. While the organization was not actively involved in the building the design theory, it granted access for in-depth data collection and analysis. The initial data collection began through engaged scholarship with the case organization (Van de Ven 2007). A series of personal and informal meetings with senior executives and senior business managers from the company helped secure access to the site for the research reported exclusively in this paper. After securing access to the site, an intertwined data collection and analysis was conducted (Birks et al. 2013), which means that within short timeframes following each interview, interviews were transcribed, coded, and analyzed. Initial coding followed the notion of open coding (Glaser 1978), namely, going through the data line-by-line and coding the information to generate tentative categories. As mentioned, coding was not a linear and structured process but followed the idea of iterative coding (Birks et al. 2013), whereby constant comparisons of different data slices presenting different standpoints on the same category prompted iterative cycles of coding and re-coding data and triggered new data collection and analysis activities. To manage preconceptions during our data collection and analysis, we focused on reading broadly about the studied phenomenon in preparation for and prior to interviews with key informants of our study (Birks et al. 2013). The core theme that emerged through iterative data collection and coding was digital platform design, which prompted to draw on the design science paradigm and specify the design theory development. Further data collection and analysis activities toward the development of design principles was conducted until a saturation was achieved (Charmaz 2006). In sum 22 interviews were obtained and additional data such as observations and multiple documents for triangulation, contextualization and verification purposes. On average, the interviews lasted 72 minutes, producing more than 320 single-spaced pages of text data upon transcription. The data collection on the IT transformation program was greatly enhanced by the given opportunity to work with the case organization over an extended period of more than three years. 
The case study of Weinrich et al. (2016b, paper III) explores the introduction of agile methods for DBS execution within a large German investment company. The dynamic environment, especially the increasing regulatory demands, digitalization and new competitors, led the top management to introduce agile methods in the context of its organizational DBS. However, the organization is rather familiar with classically oriented methods along with corresponding organizational structures. Similar to Gregory et al. (2017, paper II) this study follows the aforementioned iterative data collection and analysis techniques in line with the GTM (Glaser et al. 1968). It is set up as a single case, which is especially suitable for exploratory research questions where the control of contextual environment is not desired and the focus is on a contemporary events (Yin 2013). After gaining access to the case company, iterative data collection and analysis, i.e., coding was conducted. During this process, challenges for introducing agile methods for DBS execution became the core category and guided further data collection analysis until a saturation was achieved. In addition, literature on this topic was also regarded, too. In sum, thirteen semi-structured interviews were conducted with different stakeholders (Charmaz 2006; Glaser et al. 1968; Urquhart 2012). An interview lasted, on average, 64 minutes and led to 277 transcribed single spaces pages. Moreover, additional documents allowed for triangulation of the phenomenon.

As stated earlier, the study of Eickhoff et al. (2017, paper IV) develops a taxonomy of FinTech business model archetypes. The data for the empirical-to-conceptual analysis of this study were obtained from Crunchbase (2016), a company information database that offers profiles of companies, investors and incubators, individuals, and events, as well as the relationships between them. The focus of the database is especially on the start-up community and it provides a number of attributes, i.e., tags that aid users in finding find start-ups with specific characteristics. For this study, a selectable FinTechtag was used, which resulted in an initial list of 2,340 companies. In sum, Crunchbase provided the suitable data for this research endeavor: to identify patterns in the business model of FinTechs, which may represent pioneer business models for incumbents. 


\section{B. Research Areas}

The second section of this thesis contains the research papers of Weinrich (2017, paper I), Gregory et al. (2017, paper II) Weinrich et al. (2016b, paper III) and Eickhoff et al. (2017, paper IV). As presented in the section structure of the foundations part, the first three research papers belong to the research area of DBS execution and the latter belongs to the research area of digital business models. 


\section{Digital Business Strategy Execution}

The first research area I. Digital Business Strategy Execution focusses on how companies execute a DBS. As stated in the foundation part, the first aim of this research area is twofold. First, to provide a general overview on how companies engage in DBS execution. Second, to provide a more specific view on DBS execution by analyzing two cases within the financial services industry. The corresponding research questions are:

$R Q$ I.1. What is the state of knowledge on digital business strategy execution?

RQ I.2. How do financial service providers execute a digital business strategy? 


\title{
I.1. Executing Digital Business Strategy: Organizational Design
}

\section{Reviewing Organizational Design Components for Digital Business Strategy}

\begin{abstract}
The view on information technology strategy has changed significantly. In the past, a functional-level view was prevailing, where information technology (IT) strategy was subordinate to a deliberate business strategy and needed alignment. Recently, rapid developments in digital technologies leaves no industry untouched and IT becomes an enabler and differentiator for businesses. Therefore, IT strategy exceeds the view of alignment towards a fusion of business- and ITstrategy- coined as digital business strategy (DBS). Yet, strategies are inextricably linked to organizational design in order to function well. Consequently, a DBS requires a suitable underlying organizational design. This paper aims to explore the very organizational design components for DBS by examining the state of the art literature. Specifically, this paper sheds light on the organizational design components of strategy, structure, processes, rewards, and people. The research method is a review of relevant literature at the intersect of information systems (IS) and management. Conclusions, implications for research, and practice are presented.
\end{abstract}

Outlet: Weinrich, T. 2017. "Reviewing Organizational Design Components for Digital Business Strategy," Proceedings of the Bled eConference 2017, Bled, Slovenia, pp. 1-18.

Keywords: Digital Business Strategy, Organizational Design, Literature Review. 


\section{Introduction}

In the past, the predominant view on IT strategy was a functional-level view. IT strategy was treated subordinate to a deliberate business strategy and needed to be aligned with it (Henderson and Venkatraman 1993; Venkatraman 1994). However, steady improvements in price/performance ratio of technology as well as advances in information, computing, communication, and connectivity technologies bring new functionalities, which affect society and economy at large. In today's uncertain environment, IT supplies crucial dynamic capabilities and becomes an imperative part of strategy formulation (El Sawy et al. 2010; Yoo et al. 2010). For example, digital technologies (combinations of information, computing, communication, and connectivity technologies) have the power to change business strategy towards a cross functional, modular, distributed nature with global business processes that "enable work to be carried out across boundaries of time, distance and function” (Bharadwaj et al. 2013, p. 472). To capture this development, Mithas and Lucas (2010) and El Sawy et al. (2010) introduced the concept of DBS: Instead of viewing IT strategy subordinate to business strategy, the authors conceptualize a fusion of business strategy and IT strategy. The concept promotes the view, that IT strategy is much more than just a functional strategy because, nowadays, digital resources are an integral part of almost every organizational area. Digital technologies can create a differential value and increase innovative strength to generate a competitive advantage. Consequently, they are more than just systems and technologies (Bharadwaj et al. 2013). Bharadwaj (2013) further elaborate on the DBS concept and provide a general understanding of DBS. The authors identify key themes and possible research directions, which the authors center around scope, scale, speed and sources of value creation and capture of DBS. i) scope: DBS transcends functional areas, digitization of products and services, disruption of traditional supply chains towards ecosystems; ii) scale: scaling of IT as an adaptive capability, network effects enabled by multisided platforms, information abundance, scaling via partners; iii) speed: product launches, decision making, supply chain orchestration, network formation and adaptation; iv) sources of value creation and capture: increased value from information, value creation from multisided business models, value creation through coordinated business models in networks and value appropriation through the control of digital industry architecture. Whereby, Bharadwaj et al. (2013) remark that the identified trends and organizational shifts are merely illustrative and not exhaustive. 
Yet, a strategy needs a matching organizational design in order to be carried out. The organizational design may unleash organizational capabilities (combination of skills, processes, technologies, and human abilities that differentiate a company), which in turn translate to a competitive advantage - the overall purpose of strategy (Kates and Galbraith 2010). Any change in strategy requires a change of organizational design (Dosi et al. 2001). Thus, organizations that pursue a DBS also need a matching organizational design that is different from "traditional designs" (Bharadwaj et al. 2013). Similarly, Matt et al. (2015, p. 341) state "with different technologies in use and different forms of value creation, structural changes are often needed to provide an adequate basis for the new operations. Structural changes refer to variations in a firm's organizational setup [...]”. Such organizational changes are independent of the industry or organizations and usually have certain aspects in common (Matt et al. 2015). In sum, a novel organizational design under DBS is acknowledged, but no research explicitly addressees and reviews this issue, yet. Therefore, the following research question is formulated to address this research gap: "What is the state of knowledge on organizational design in the context of digital business strategy?” In order to answer the research question, we adopt the organizational design perspective of Galbraith (1977), a well-established organizational design framework, which consists of five interrelating categories: strategy, structure, processes, rewards, and people (see 2.2 Framework). Accordingly, the unit of analysis is on the organizational level perspective.

\section{Methodology}

\subsection{Literature Review}

Guzzo et al. (1987) present common review types, which can be subsumed as narrative, descriptive, box score, and meta-analysis. More recently, a detailed view on different review types is introduced by Paré et al. (2015). The authors develop a typology shown in "Table 4: Literature review types”, including a brief description of each type (next page). 


\section{Review Type}

Narrative

Descriptive

Scoping/ mapping

Meta-analyses

Qualitative systematic reviews

Umbrella/overview

Theoretical

Realist/ meta-narrative

Critical

Table 4: Literature review types by Paré et al. (2015).

This piece of research is most in line with a descriptive review type because it shares numerous aspects with this type: (i) it summarizes the prior knowledge, (ii) the scope of the research question is relatively broad, (iii) the search process (following paragraph) is comprehensive, (iv) the identified literature is of conceptual and empirical nature, (v) the identified literature is selected via certain predefined selection criteria (following paragraph), (vi) due to the relatively young phenomenon of DBS, an appraisal for only high quality is not the focus (vii) synthesizing and analyzing the identified literature centers thematically around a given framework (following section) (Paré et al. 2015).

A detailed and systematic search process is important to yield a rigorous, unbiased, objective, transparent and replicable review. Therefore, a review should provide explicit information on how the literature is identified, selected, assessed and synthesized. First, it should outline the research question(s), sources searched, search terms, search strategy and inclusion / exclusion criteria. Afterwards, the actual search is performed. The relevant literature is selected according to the chosen criteria and subsequently analyzed. Evidence is summarized and presented (Boell and CecezKecmanovic 2014; Wolfswinkel et al. 2013).

The research questions, already presented in the introduction, is: "What is the state of knowledge on organizational design in the context of digital business strategy?". The initial keyword search for the topic relevant literature is conducted by drawing on 50 major IS journals and 16 IS conferences as proposed by Levy and Ellis (2006, p. 186). It is complemented by the Financial Times 50 journals (FinancialTimes 2017). In doing so, the scope of our search covers the dual aspects of DBS and organizational 
design for this study, i.e., management literature on the one hand and IS literature on the other hand. In the following, three major steps to conduct this literature review are presented: (i) keyword search, (ii) backward search and (iii) forward search (Webster and Watson 2002):

(i) The keywords applied for searching within the journals and conference proceedings are "digit* business strateg*" OR "digit* strateg*", whereby asterisks are placed to cover any variation of the words. The keyword search is applied to peer-reviewed only and title, abstract and keywords fields (if not available, full text). The selection for relevant articles takes places by reading the title, keyword, and abstract first (or further if still unclear). The criteria for judging the relevancy of the obtained articles is an explicit (i) linkage to DBS and (ii) linkage to the organizational design framework (following section 2.2 Framework).

(ii) The next step is to perform a backward search, i.e., reviewing the citations of all relevant articles identified during the keyword search. Applying the same selection criteria for the backward search one obtains relevant prior articles that should be considered for this study.

(iii) Finally, the last step is the forward search, which is the process of identifying relevant articles that build on the previously identified articles, also known as cited by. For this process, Web of Science and Google Scholar are used because both search engines proved to show occasionally diverging search results and therefore complement each other. Again, for this step the introduced relevancy criteria are applied, which resulted in the final sample of 39 articles (see the table in the appendix with the concept matrix of the analyzed articles).

\subsection{Framework}

Organization $^{1}$ design can be viewed as a chain of decisions and choices and collectively refers to the "process of configuring structures, processes, reward systems, and people practices to create an effective organization capable of achieving the [digital] business strategy” (Kates and Galbraith 2010, p. 1). Initially, it originates from Galbraith (1977) well-established organizational design framework that consists of the intertwined components of strategy, structures, processes, rewards and people. The following paragraph introduces each component briefly.

\footnotetext{
${ }^{1}$ The working definition of organization is the "entire firm, as well as to just one part of it" Kates and Galbraith (2010, p. 1) - if not explicitly named otherwise e.g., IT/IS or business organization.
} 
The component strategy determines a company's course of action and can be understand as the cornerstone of the organizational design. It origins from the decisionmakers' understanding of the various environmental influences such as new technologies, competitors, customers, suppliers etc. Essentially, it is the success formula to gain a competitive advantage and differentiation.

Structure refers to the organizational chart and key roles. Some common types of organizational structures are functional, product, geographic, or customers-centric structures. It represents the possibilities of how to group different people together in an organization. Furthermore, it clarifies responsibilities, decision-making powers, and authorities.

The component processes refers to any connected activity that is linked with the information flow within and across an organization. Processes dissolve collaboration barriers that may result from an organizations' structure. Well-designed processes ensure that e.g., the right people find each other to innovate a new product or to develop a new standard. Processes can determine mechanisms for collaboration and therefore how well units within and across organizations work together.

Rewards have the purpose to harmonize the behavior and performance of individuals with the overall goals of an organization. It includes e.g., rewards based on measures or variable compensation.

The component people contains practices like selecting, training, staffing and developing of people to gain desired capabilities and a mind-set to successfully execute the strategy. This may include e.g., competencies like interpersonal skills and decision making capabilities such as considering multiple points of view (Kates and Galbraith 2010).

\section{Findings}

The following subsections present the findings of the identified literature on DBS and organizational design along the framework's components of strategy, structure, processes, rewards, and people. Whereby, the appendix includes a summarizing concept matrix and a figure showing cumulative articles published on DBS and organizational design components. 


\subsection{Strategy}

Following a DBS implicates establishing new dynamic capabilities, e.g., process-, customer and performance management (Mithas et al. 2012). Specifically, organizations desire an increased agility and responsiveness, multi-channel ecosystem connectivity, visualization and governance of data and information. In order to obtain this, organizations need to invest in multiple IT-enabled efforts (Freitas Junior et al. 2016). In fact, Mithas et al. (2013) show that under higher industry dynamics, organizational spending differs for DBS related activities and vice versa for industry growth and concentration. Technology related investments may allow organizations to solve ambidextrous strategies, like a DBS, because it often involves pursuing multiple goals at once e.g., by following revenue growth and cost reduction at the same time (Bonchek and France 2015; Mithas et al. 2012). However, Woodard et al. (2013) show that organizations are path-dependent when it comes to designs of their existing digital artifacts. The authors refer to "design moves", resulting options/debt of past investments that enable/constrain strategic actions of organizations. Strategic paths can also be disrupted via a destabilization of self-reinforcing mechanisms resulting from digitalization (Wenzel et al. 2015). Though, DBS is not only about optimizing internal operations or responding to single competitors, it is also about the responsiveness and awareness of the whole competitive environment (Mithas et al. 2013). This may open up new choices for digital business models, like Netflix, who first started with efficient delivery system of physical DVDs and later, due to digitization of media, the organization seized the opportunity and became the market leader for online media streaming (Mithas and Lucas 2010). Therefore, IT does not just support strategic goals but increasingly becomes an enabler of strategic goals (Hess et al. 2016). As strategy originates from the decision makers understanding of environmental influences (Kates and Galbraith 2010), for DBS, this is especially the case for pervasive digital technologies (Bharadwaj et al. 2013). Digital technologies increasingly become an integral part of DBS formulation (Yoo et al. 2010). In line, the identified literature shows, that many DBS of organizations encompasses engaging in harnessing digital technologies to gain a competitive advantage and differentiation.

It includes engaging in social media for various purposes. Organizations increasingly use social media such as wikis or blogs for internal and external communication and collaboration (Delerue and Vuori 2012; Ross et al. 2016). Regarding social networks, organizations leverage and create value from it by fostering additional transactions out 
of social media relationships. Catlin et al. (2014) emphasize to digitally connect with (existing) customers by extending digital marketing activities, to retain customers and improve cross- and up-selling. A more nuanced view is provided by OestreicherSinger and Zalmanson (2013), who demonstrate that social media should not just be a substitute to offline marketing activities. In order to generate value from social media, organizations need to "[...]take a strategic rather than techno-centric view of social media, that integrate social media into the consumption and purchase experience" (Oestreicher-Singer and Zalmanson 2013, p. 591). However, social media does not always complement organization's DSB. Increasingly, it has the power to compete with organizations, such as news media or mobile services providers (Palekar and Sedera 2015).

Yet, social media is much more of just another customer touchpoint. Next to wearables, tracking customers via cookies or app permissions etc., social media is a valuable source of information. For example, combined with data analytics it yields customer insights and a better customer understanding (Catlin et al. 2014). Analytics can provide meaningful insights and enable organizations to scale recommendations and offer products and services on a highly personalized level (Bonchek and France 2015; Ross et al. 2016). Thus, the analysis of large data is often an integral part of DBS to e.g., become a more customer centric organization because "[...]the buyer, not the seller, determines which dimensions of value matter and how offers compare” (Keen and Williams 2013, p. 644). Other application fields of analytics within DBS also include the support for strategic and tactical decision-making and business processes (Watson et al. 2006). In sum, analytics of large datasets are a key within DBS (Bhimani 2015) and it has the power to create a sustainable competitive advantage (Erevelles et al. 2016).

Next to social media and analytics, cloud computing is also frequently mentioned in the identified articles. Yet, Goutas et al. (2015) highlight, that many organizations adopt it without having a clear DBS. In order to unleash the full potential of cloud computing, it not only has to fit to the existing processes and systems, but also has to be part of an overall DBS. DBS on cloud computing usually encompass the intention for optimization, innovation and/or disruption (Berman et al. 2012b). Nevertheless, the overall focus should be the value creation to customers by e.g., increasing software security and customization. Only then, cloud computing enables DBS to transition to new, digital business models (Berman et al. 2012a). Likewise, in a qualitative study 
Cowen et al. (2016) show, how cloud computing increasingly becomes an integral part of organizations DBS in a developing country. Their main findings indicate that via cloud solutions, organizations achieve a better return on capital, improved quality and efficiency, better customer relationship and innovation acceleration and it has a cultural impact.

Finally, Ross et al. (2015) highlight that, in order to realize a competitive advantage from digital technologies in general, organizations need to gain a holistic picture and not just focus on individual solutions. This means, to invest with caution, to achieve integrated and not just isolated solutions. For example, not only to just invest in mobile technology by offering apps and customer service (Catlin et al. 2014). Overall, “[...]a strategic focus that directs their technology spending [on] social, mobile, analytics, cloud, and internet of things technologies” (Ross et al. 2015, p. 2), is needed to foster new capabilities that make sense for DBS.

\subsection{Structure}

To implement a DBS successfully, organizations have to align their structure correspondingly. Literature shows, that there are several common practices for DBS. In general, Catlin et al. (2014) emphasize, that the governance and operating model need to fit to the organizations "digital maturity". Together with an increasing digital maturity a lot of the organizational functions become decentralized and embedded in business unit activities. Increasingly, organizations create units that consist of crossfunctional teams e.g., of technology and operation for business lines, to achieve a better responsiveness (Sia et al. 2016). Others contributions highlight the launch of innovation labs detached from an organization (Ross et al. 2015). In sum, organizations need to decide whether and how to integrate digital operations into their existing structures or separate it from the core business (Hess et al. 2016).

Additionally, DBS needs to be communicated organization wide by the senior management and managers at all levels across an organization should be enlisted in technology decisions. In so doing, Mithas and Lucas (2010) and Sia et al. (2016) point out, that the Chief Executive Officer (CEO), Chief Information Officer (CIO) and the senior management need to work tightly together to execute DBS. For example, the “CIOs must engage their business counterparts to shape IT decisions and create buyin for IT efforts” (Mithas and Lucas 2010, p. 4). Likewise, not all power over the DBS should be located at a single department, for example, at the marketing department, 
which might only lead to customers' attention shortly but will not provide sustainable value (Haque 2015). Some organizations introduce a Chief Digital or Data Officer (CDO), a dedicated position within an organization who is in charge of the DBS. In this case, too, interactions and collaboration between the CDO and the other management is critical for DBS success. The CDO role, tasks, responsibilities and reporting structure need to be articulated clearly - particularly with respect to the CIO as a neighbored manager (Haffke et al. 2016; Hansen and Sia 2015; Horlacher 2016). Especially, since it is known that a tight CIO-CEO reporting structure is beneficial for differentiation (Banker et al. 2011). Thus, the reporting structure needs to fit to the DBS of an organization. In sum, DBS affects the whole organizational structure along with the power over the DBS execution, which may vary from organization to organization (Hess et al. 2016). In line, Matt et al. (2015) come to the conclusion, that there is no distinct answer yet, who should be in charge of the DBS.

\subsection{Processes}

As introduced, the component processes refers to any connected activity that is linked with the information flow within and across the organization. The following paragraphs highlight the (i) information flow within an organization, (ii) the information flow from the outside in and, (iii) from the inside out of an organization.

First, the credo for DBS is "what can be digitized will be digitized" to cut costs and increase service quality. Therefore, digitization, optimization and standardization of processes are imperative to allow for e.g., straight-through processing or and rapid product configuration (Catlin et al. 2014; Hess et al. 2016; Ross et al. 2016). As already mentioned for the component structures, teams from different departments or innovation labs are a common practice. The intention is to achieve a culture of experimentation, agility for innovation processes and an increase in the speed of product launches. This includes “test-and-learn” processes to allow failure as an example for new product development and as a part of the innovation process (Bonchek and France 2015; Ross et al. 2016; Sia et al. 2016). It is increasingly encouraged that every employee can participate and give feedback (Sia et al. 2016). Additionally, social media is often used to internally or externally crowdsource ideas (Delerue and Vuori 2012). Under DBS sophisticated customer service processes are gaining more and more importance to achieve customer orientation and customer response in order to answer changing customer demands. Setia et al. (2013, p. 585) 
exemplarily state that for "[...]the sophistication of customer service processes and goals of customer service performance, firms may customize their initiatives to build effective digital designs across customer service units”.

Second, nowadays organizations usually operate within whole business ecosystems and make use of shared products and platforms and processes become increasingly commoditized. Markus and Loebbecke (2013) introduced the term “commoditized processes”, which are processes that are conducted in the same way, for example by using SAP or Salesforce. In contrast to standardized processes can still be customized individually e.g., an industry norm. Organizations that use commoditized processes do not necessarily have to interact in some way, but it can accelerate activities like (future) partnering or outsourcing (Markus and Loebbecke 2013). Yoo et al. (2010) point out, that it can be a challenge for organizations to coordinate and manage distributed and dynamic processes of maintaining and designing IT infrastructures at a corporate level. Nevertheless, it is not a question of if but how to interface to customers, partners and suppliers because they are a critical source of innovation under DBS (Keen and Williams 2013). More and more, organizations need to be able to integrate and process heterogenic internal and external information and knowledge resources. Being able to combine and store data from various databases can be used for different fields of application (Ross et al. 2016), such as a seamlessly omni-channel experience for customers (Hansen and Sia 2015) or speed up the decision making process by using e.g. real-time business intelligence (Watson et al. 2006). In addition, it becomes increasingly important to not only know the customer but also to process and lever relevant information e.g., via analytics as shown in the subsection strategy (Bonchek and France 2015). This also requires integrating different sources of information such as new channels like apps, social media and webpages, not only with traditional offline channels but also with the inventory management system (Oestreicher-Singer and Zalmanson 2013; Ross et al. 2015; Ross et al. 2016).

Third, in today's world of ubiquitous information, stakeholder of an organization like their customers are empowered, well informed and want organizations to be transparent about their product quality, features, etc. in order to trust them (New 2010). Therefore, organizations need to take care of the process, which and how information flows from the inside out. (Granados and Gupta 2013) argue that transparency is a relevant part of DBS and organizations should selectively and strategically disclose information that is desired by stakeholders. Nevertheless, Grover and Kohli (2013) 
debate, that organizations need to be cautious about exposing systems' software, process, and information, which might expose strategic intentions to competitors and thus potentially give away a competitive advantage. In line, Dewan et al. (2007) highlight that transparent information, such as stock and price information, could also be used by competitors and not only by customers. In sum, under DBS the information flow out of an organization can be described as a balancing act of giving away just the right information to stakeholders (Grover and Kohli 2013).

\subsection{Rewards}

The organizational design component rewards shows the fewest results in the literature. Only Catlin et al. (2014) emphasize that organizations need to reward a more risk-taking behavior, which should yield in a test-and-learn culture. However, the authors are not explicit on how this behavior is rewarded only that "digital spend [should be] measurable in terms of return on investment.” (Catlin et al. 2014, p. 3). Similarly, when it comes to the specific person(s) that are in charge of the DBS endeavor, their incentives should be directly linked to the target and progress of the DBS (Matt et al. 2015).

\subsection{People}

The role of digital talents is crucial for organizations that engage in DBS because new skillsets are required as digital technologies impact organizations at large (Hess et al. 2016). For example, it requires managers to not solely think in terms of business or IT but with a deep understanding of DBS (Bonchek and France 2015). Specifically, competencies and knowledge is required on how to synchronize IT and business strategy, IT governance, implement IT projects, and manage the organizational IT infrastructure in order to be successful in DBS (Haffke et al. 2016; Hansen and Sia 2015; Mithas et al. 2012; Mithas and Lucas 2010; Valentine and Stewart 2015). Leaders need to be open towards innovation and know how digital technologies and ubiquitous information affect their organization. This also includes an organization's ecosystem, which includes their stakeholders like customers, alliances, employees, suppliers etc. Such an understanding is the foundation to lever digital resources and create value for an organization (Bennis 2013; Favaro 2016; Sia et al. 2016). In so doing, it may help an organization to preserve a competitive advantage or to gain new competencies and define a new competitive advantage (Mithas et al. 2012; Mithas and Lucas 2010). Nevertheless, managers need to be capable to communicate the DBS and 
their beliefs organization wide to create a common understanding (Mithas and Lucas 2010). This is especially important because DBS affects the whole organization and any change may bring resistance to some degree (Matt et al. 2015). Digital talents can either be recruited externally or internally, by hiring people with the sufficient experience from academic institution or other (digital) organizations, mergers and acquisitions or training via dedicated digital training programs (Catlin et al. 2014; Hess et al. 2016; Matt et al. 2015).

\section{Summary and Conclusion}

Overall, this literature review contributes to the body of DBS and organizational design. It sheds light on DBS and organizational design by specifically looking at the components of strategy, structure, processes, rewards and people (Bharadwaj et al. 2013; Galbraith 1977). Considering strategy, it is evident, that digital technologies have to be an integral part of DBS. Yet, the majority of identified articles specializes on certain digital technologies under DBS and do not treat them in a holistic manner as frequently emphasized (Ross et al. 2015). Additionally, there is a strong focus on harnessing cloud computing, analytics and social media under DBS. Whereas, mobile technologies are underrepresented but not less important (Cisco 2017). In terms of structures, this piece of research points out that under DBS organizational functions become increasingly decentralized. It is also evident that the reporting structures and decision-making power shifts since DBS is an organization-wide endeavor and needs orchestration within and across the organization. However, how organizations achieve this is quite heterogeneous (Matt et al. 2015). In regard to the component processes, an increasing interfacing with the ecosystem, which includes customers, partners, suppliers and possibly competitors, is key. Organizations need to be capable to lever their ecosystem because it is a critical source of value creation by e.g., fostering innovation (Keen and Williams 2013). Regarding the component rewards, this literature review found surprisingly little on harmonizing individual behavior with the overall goal of an organization. While literature mentions the importance of this aspect, only little information is given. Finally, the component people shows that to enable a DBS, digitally skilled employees and leaders are needed, which understand digital technologies, their strategic implications and know how to create business value from it. Overall, this literature review is able to show that in order to carry out a DBS, organization design requires a large shift. Yet, the presented organizational design 
components for DBS should not be treated mutually exclusive but as interrelating components, which need to be closely aligned to complement each other to be successful.

Limitations of this literature review exist because, for example, an organizational design perspective is adopted, which inhibits an in depth examination of DBS from an ecosystem perspective - another important aspect of DBS e.g., Pagani (2013). Additionally, only literature is included that explicitly refers do digital strategy / digital business strategy and components of the framework.

This contribution has practical and research implications likewise. The practical implications highlight the need for a suitable organizational design under DBS. In doing so, this review also shows practical audience, common organizational shifts for the components strategy, structures, processes, rewards and people. These design components are directly under the control of leaders and, therefore, organizations pursuing a DBS can draw from these insights and transfer them to their organizational context. Moreover, companies should reconsider existing portfolios of single DBS speedboat initiatives and treat them in a more holistic manner by orchestrating them. By doing so, the initiatives complement each other meaningfully and unleash their full potential.

Common research implications for literature reviews are uncovering research gaps and pinpointing possible future research questions. Thus, a review typically can give guidance for future research (Webster and Watson 2002). For strategy, possible future research directions encompass how and which single and formerly isolated solutions in social, mobile analytics, and cloud technologies complement each other. Due to this, future research is emphasized to yield an integrative and holistic picture of digital technologies under DBS. In addition, mobile devices are getting smarter and mobile data traffic is increasing exponentially (Cisco 2017). Yet, their implications for DSB are still not fully examined and require future research. For the component structure, one can observe heterogeneous approaches of organizations. Therefore, an analysis of which structure may lead to superior organizational performance is emphasized. This may include reporting structures and distribution of power in general, new roles like the CDO, team settings like cross-functional teams etc. For the component processes, integrating and analyzing different sources of large amounts of information becomes increasingly important differentiator and a source of value. Yet research at the intersection of DBS and digital business infrastructure, i.e., how do incumbent firms 
build a digital business infrastructure, is still scarce. Another research gap is evident for the component rewards. Future research may look at how to harmonize individual behavior with DBS, including metric and measures. Finally, organizational design can influence not only organizational performance but also organizational culture (Kates and Galbraith 2010). Organizational culture is an output of the "[...]cumulative design decisions that have been made in the past and of the leadership and management behaviors that result from those decisions.“ (Kates and Galbraith 2010, p. 3). This means leadership cannot directly influence organizational culture but indirectly via the organizational design. The impact of DBS on organizational performance has been proposed and examined in some recent contributions, e.g. (Freitas Junior et al. 2016; Leischnig et al. 2016). However, little is known on how culture changes or looks like under an organizational design for DBS. Therefore, future research should elaborate on this topic. Additionally, drawing on a different framework for DBS could yield additional insights. Finally but yet importantly, a change in organizational design under DBS indents to unleash new capabilities, that in turn may lead to a new business models (DaSilva and Trkman 2014). Thus, questioning, what are new or typical business models resulting from pursing DBS with a corresponding organizational design? 


\section{Appendix}

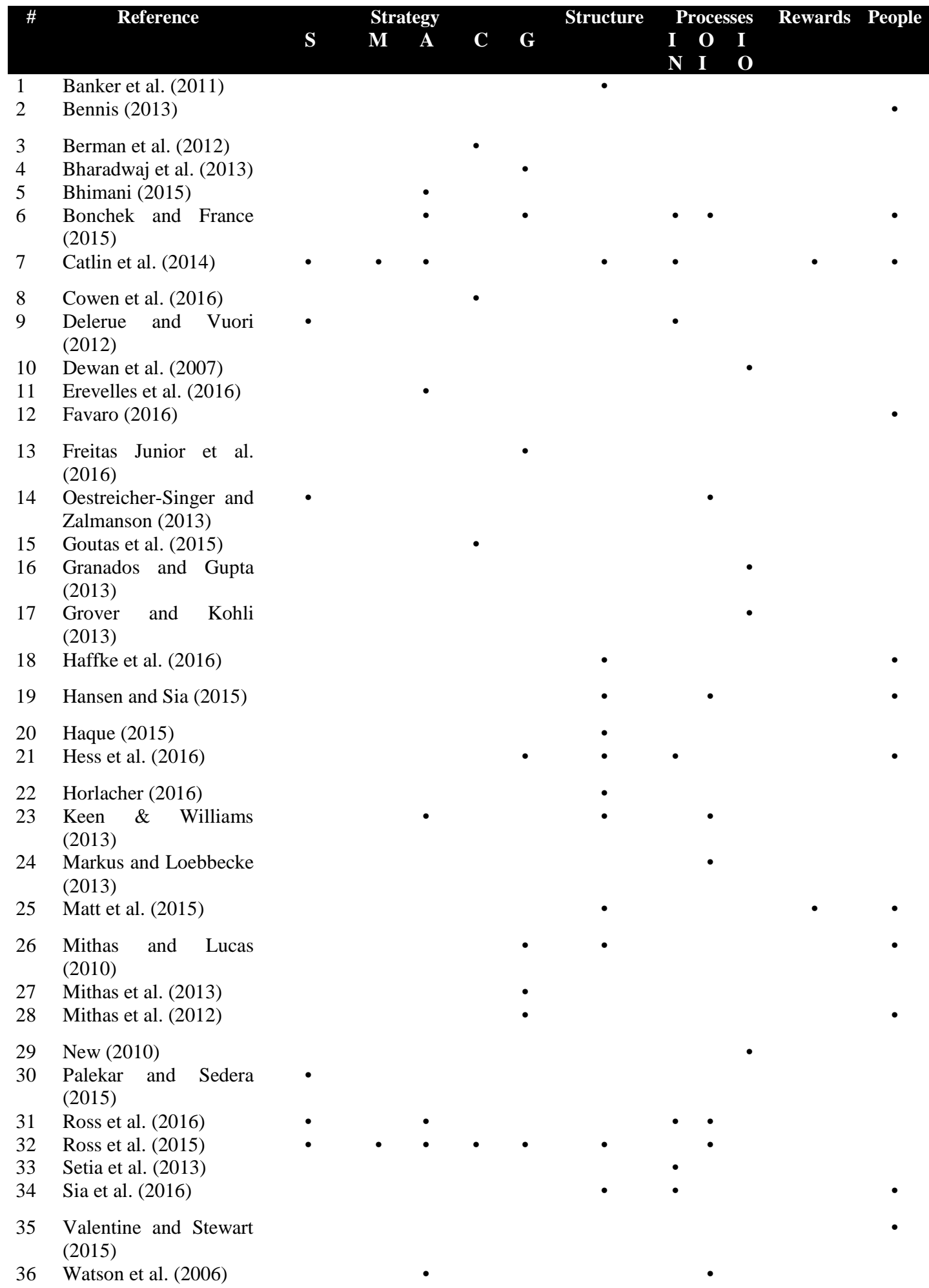


Table 5 cont.

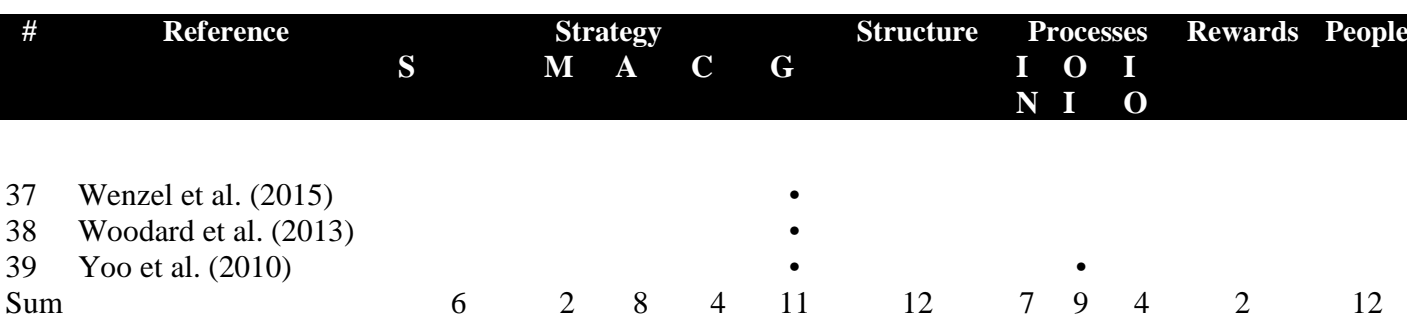

Table 5: Concept matrix of analyzed articles and organizational design components. $S=$ social media, $\mathrm{M}=$ mobile technologies, $\mathrm{A}=$ analytics $\mathrm{C}=$ cloud computing, $\mathrm{G}=$ general, $\mathrm{IN}=$ Information flow within an organization, OI=Information flow outside in of an organization $\mathrm{IO}=$ Information flow inside out of an organization.

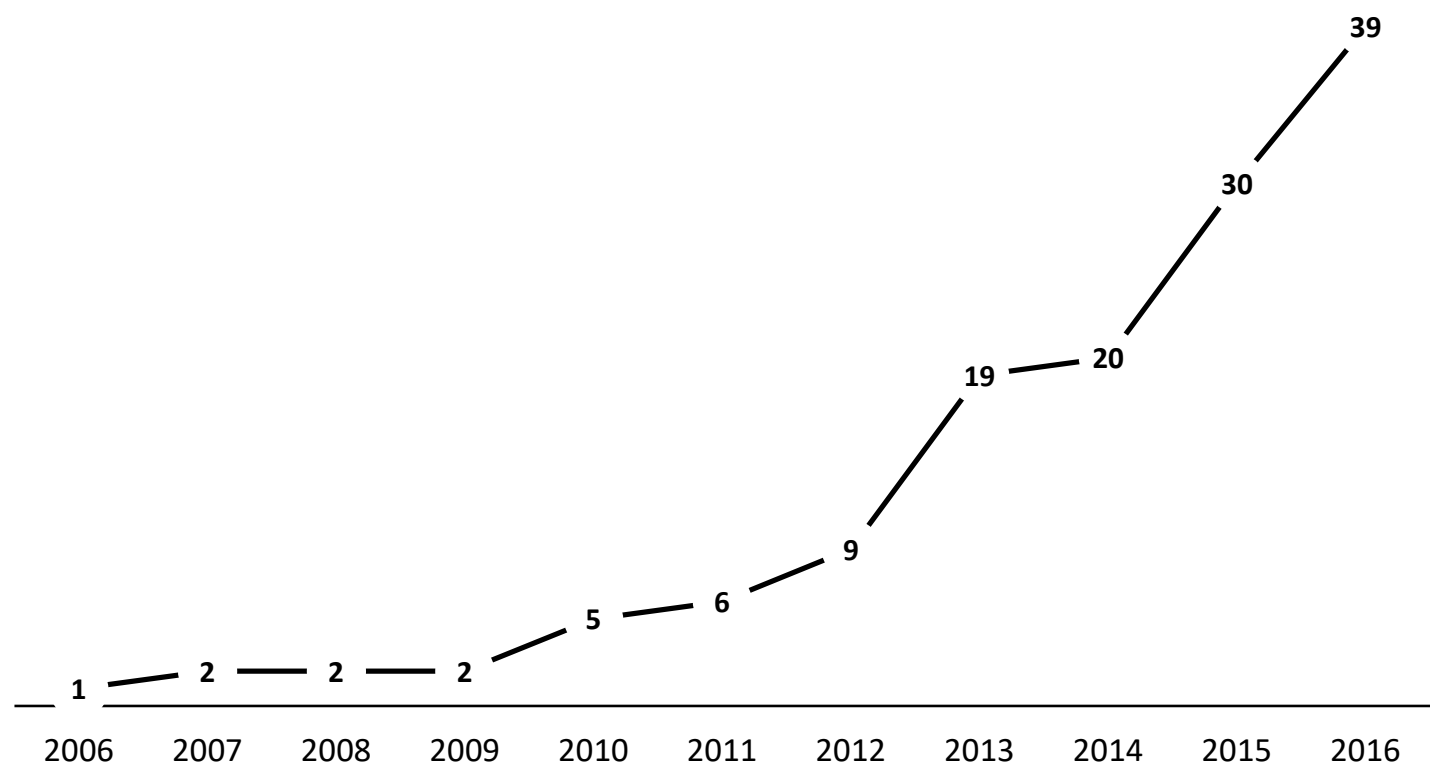

Figure 2: Cumulative articles published on DBS and organizational design components. The numbers on the line represent the cumulative articles published up to the corresponding year. 


\title{
I.2. Executing Digital Business Strategy: Digital Platform
}

\section{Designing a Digital Platform for Multi-Firm Value Co- Creation}

\begin{abstract}
While much is known about the dynamics of and how to govern digital platforms, an important gap in our understanding exists regarding the socio-technical platform design choices that help resolve the fundamental tension between IT efficiency and IT flexibility to enable multi-firm value co-creation. We examined the case of a financial data brokerage and services provider that transformed its existing IT architecture into a digital platform. Drawing on the design science paradigm, we extracted a set of design principles that highlight a both/and approach to combining IT efficiency and IT flexibility to enable multi-firm value co-creation. Our findings show that firms confronting the rise of digital business strategy must transform their IT architecture into a digital platform that achieves a synthesis between IT efficiency and IT flexibility by incorporating the design principles of reliability-responsiveness (platform infrastructure layer), controlextensibility (platform data layer), and standardization-variety (platform services layer).
\end{abstract}

Outlet: Abstract only, see Wirtschaftswiss_PhD_PStO_2016_AM56, § 29 Veröffentlichung der Dissertation, Absatz 10.

Gregory, R. W., Weinrich, T., Muntermann, J., and Káganer, E. 2017. "Designing a Digital Platform for Multi-Firm Value Co-Creation," (research in progress based on Weinrich et al. 2016a), pp. 1-49.

Keywords: Digital Business Strategy, Digital Platform Design, IT Value CoCreation, Blending IT Efficiency and IT Flexibility, Design Science.

Prior Weinrich, T., Muntermann, J., and Gregory, R. W. 2016a. "Exploring Version: Principles for Corporate Digital Infrastructure Design in the Financial Services Industry," Proceedings of the Pacific Asia Conference on Information Systems 2016, Chiayi,Taiwan, pp. 1-15. 


\title{
I.3. Executing Digital Business Strategy: Agile Approaches
}

\section{Herausforderungen bei der Einführung agiler Vorgehensmodelle für Finanzdienstleister - eine Fallstudie}

\begin{abstract}
Abstract: Im Spannungsfeld der digitalen Transformation führen zunehmend auch bisher traditionell agierende Unternehmen agile Vorgehensmodelle ein. Das Interesse an agilen Vorgehensmodellen wird insbesondere durch die steigende Komplexität durchgeführter Projekte und neuen Herausforderungen aufgrund der Digitalisierung begründet. Der Einführung agiler Vorgehensmodelle stehen hierbei jedoch oft historisch gewachsene Rahmenbedingungen gegenüber, welche mit agilen Vorgehensmodellen nur bedingt vereinbar sind. Am Fallbeispiel eines Unternehmens der Finanzwirtschaft, welches im Rahmen der digitalen Transformation agile Vorgehensmodelle einführen möchte, zeigt der Beitrag auf, welche Herausforderungen für solche Unternehmen besonders ausgeprägt sind. Hierzu werden zuerst die existierenden Rahmenbedingungen des Unternehmens dargelegt, um anschließend aufzuzeigen, wie diese die Einführung agiler Vorgehensmodelle beeinflussen können. Die Analyse fußt auf Experteninterviews im Bereich des IT-Projektmanagements, welche mittels Techniken der Grounded-Theory-Methodik ausgewertet wurden. Abschließende Implikationen und Handlungsempfehlungen werden aufgezeigt.
\end{abstract}

Outlet: Weinrich, T., Volland, A., and Muntermann, J. $2016 \mathrm{~b}$. "Herausforderungen Bei Der Einführung Agiler Vorgehensmodelle Für Finanzdienstleister-Eine Fallstudie," Proceedings of the Gesellschaft für Informatik e.V., Lecture Notes in Informatics, Projektmanagement und Vorgehensmodelle 2016, M. Engstler, M. Fazal-Baqaie, E. Hanser, O. Linssen, M. Mikusz and A. Volland (eds.), Paderborn, Germany, pp. 79-91.

Keywords: Einführung agiler Vorgehensmodelle, Herausforderungen, Finanzdienstleister, Fallstudie.

Note This article is available in German only. 


\section{$1 \quad$ Einleitung}

Das agile Manifest mit seinen zwölf Prinzipien, welches vor fünfzehn Jahren verfasst wurde, hat die Art und Weise der Softwareentwicklung nachhaltig beeinflusst (Beck et al. 2001). Unterschiedlichste Vorgehensmodelle fußen auf den Wurzeln des Manifests, wie zum Beispiel Scrum, eXtreme programming, lean software development, feature-driven development und weitere (Dingsøyr et al. 2012). Agile Vorgehensmodelle haben „Agilität“ zum Ziel, sprich, die fortwährende Bereitschaft schnelle Veränderungen herbeizuführen, proaktiv oder reaktiv auf Veränderungen zu reagieren und gleichzeitig auch aus Veränderungen zu lernen. Wobei das Zusammenspiel der Praktiken agiler Softwareentwicklung und dessen Beziehungen zur Umwelt einen positiven Kundennutzen schaffen (Conboy 2009). Getrieben durch digitale Technologien (Social Media, Mobile, Cloud und Big Data Technologien (Bharadwaj et al. 2013), haben sich in den letzten Jahren die Rahmenbedingungen für viele Unternehmen stark verändert. Insbesondere für traditionelle Unternehmen, wie etablierte Finanzdienstleister mit historisch gewachsenen Strukturen stellt diese Veränderung der Umwelt eine Herausforderung dar. So befinden sie sich in einem tiefgreifenden Strukturwandel. Die Gründe hierfür sind vielfältig: Die Nachfrage der Kunden hat sich in Richtung individueller, das heißt insbesondere personalisierte Produkte, gewandelt. Die Ansprache und Produktangebote sollen zudem über unterschiedliche Vertriebskanäle und digitale Medien immer und überall verfügbar sein. Weiterhin betreten im Spannungsfeld der digitalen Transformation zunehmend neue Wettbewerber mit disruptivem Potential traditionelle Geschäftsfelder von Finanzdienstleistern. Im Vergleich zu diesen müssen Finanzdienstleister zusätzlich strengere regulatorische Vorschriften beachten. Zudem besteht ein Vertrauensverlust der Kunden, welche insbesondere aus der Finanz- und Eurokrise resultiert. Weiterhin müssen Antworten auf veränderte Rahmenbedingen wie die anhaltende Niedrigzinsphase gefunden werden.

Vor diesem Hintergrund werden agile Vorgehensmodelle vermehrt für die Umsetzung von Projekten genutzt. Die Einführung agiler Vorgehensmodelle birgt jedoch oft Herausforderungen für traditionelle Finanzdienstleister, besonders, wenn hierfür notwendige Rahmenbedingungen nicht geschaffen wurden. So schlägt insgesamt jedes dritte agile Projekt fehl und für jedes fünfte gescheiterte Projekt sind die Gründe sogar unklar (Kropp and Meier 2013). Traditionelle Finanzdienstleister besitzen zumeist historisch gewachsene, pfadabhängige Strukturen, Kulturen und 
Managementpraktiken, welche oft auf klassische Vorgehensmodelle wie dem Wasserfall oder V-Modell ausgerichtet sind. Diese Grundlage eignet sich aber nur bedingt für agile Vorgehensmodelle. Insgesamt ist die Einführung agiler Vorgehensmodelle als ein komplexes Unterfangen zu betrachten (Sircar et al. 2001). Dementsprechend ist das Verständnis organisationsweiter Rahmenbedingungen und daraus resultierender Herausforderungen essentiell, um einen solchen Wandel erfolgreich zu vollziehen und agile Vorgehensmodelle zu unterstützen. Hieraus leitet sich die Forschungsfrage des vorliegenden Beitrags ab: „Welche Herausforderungen existieren bei einem traditionellen Finanzdienstleister bei der Einführung agiler Vorgehensmodelle? “ Diese Forschungsfrage wird mittels einer Fallstudie adressiert, die bei einer der größten Fondsgesellschaften Deutschlands durchgeführt wurde. Diese befindet sich im Spannungsfeld der digitalen Transformation, welches auch mittels agiler Vorgehensmodelle (Scrum) im Projektmanagement begegnet werden soll. Zur Beantwortung der Forschungsfrage wurden Experten-Interviews durchgeführt. Hierbei wurden die Rahmenbedingungen festgestellt, welche zu existierenden bzw. von den Experten antizipierte Herausforderungen für die Einführung agiler Vorgehensmodelle führen. Die Beantwortung der Fragestellung ist von wissenschaftlicher und praktischer Relevanz, weil eine Vielzahl etablierter Finanzdienstleister mit ähnlichen Rahmenbedingungen eine digitale Transformation noch bevorsteht oder diese gerade durchlaufen.

\section{Relevante Grundlagen}

Agile Vorgehensmodelle wie etwa Scrum, eXtreme programming, lean software development, feature-driven development und weitere (Dingsøyr et al. 2012), entstanden als Gegenpol zu klassischen Vorgehensmodellen. So existieren in der Literatur Erkenntnisse bezüglich der Unterscheidungsmerkmale beider Vorgehensmodelle, welche sich in Tabelle 6 „Gegenüberstellung traditionelle und agile Softwareentwicklung“ (Nerur et al. 2005) (nächste Seite). 


\begin{tabular}{|c|c|c|}
\hline Merkmal & Traditionell/ klassisch & Agil \\
\hline $\begin{array}{l}\text { Fundamentale } \\
\text { Annahme }\end{array}$ & $\begin{array}{l}\text { Systeme sind voll spezifizierbar } \\
\text { und können durch genaues } \\
\text { planen entwickelt werden }\end{array}$ & $\begin{array}{l}\text { Hoch-qualitative, adaptive } \\
\text { Software, entwickelt von } \\
\text { kleinen Teams, stetigen } \\
\text { Designverbesserungen und } \\
\text { testen durch schnelles } \\
\text { Feedback } \\
\text { Veränderungen }\end{array}$ \\
\hline Kontrolle & Prozess-zentrisch & Individuen-zentrisch \\
\hline Management Stil & Anordnungen und Kontrolle & Führung und Kollaboration \\
\hline Kommunikation & Formal & Informal \\
\hline Rolle des Kunden & Wichtig & Kritisch \\
\hline Projekt Zyklus & Task und Aktivitäten orientiert & Produktfeature orientiert \\
\hline Entwicklungsmodell & $\begin{array}{l}\text { Lebenszyklusmodell } \\
\text { (Wasserfall oder ähnliches) }\end{array}$ & Evolutionäres Modell \\
\hline Organisationsstruktur & $\begin{array}{l}\text { „Mechanistisch“, hohe } \\
\text { Formalisierung, bürokratisch }\end{array}$ & $\begin{array}{lr}\text { „Organisch“, flexibel und } \\
\text { partizipativ, } \\
\text { Kooperation }\end{array}$ \\
\hline Technologie & Keine Einschränkungen & $\begin{array}{l}\text { Bevorzugt Objekt- } \\
\text { orientierte Technologie }\end{array}$ \\
\hline
\end{tabular}

Table 6: Gegenüberstellung traditionelle und agile Softwareentwicklung (Nerur et al. 2005).

Zwischen beiden Vorgehensmodellen haben sich ebenfalls hybride Varianten, die Kombination aus agilen und klassischen Vorgehensmodellen, etabliert. Diese erlauben es auch, auf projektspezifische Anforderungen einzugehen und diesen gerecht $\mathrm{zu}$ werden (Aldushyna and Engstler 2015).

Die Faktoren, die bei einer Einführung agiler Vorgehensmodelle entscheidend sind, lassen sich allgemein in folgende vier Dimensionen kategorisieren: Organisation, Menschen, Prozesse und Technik (Chow and Cao 2008; Nerur et al. 2005). Im organisationalen Kontext ist beispielsweise bekannt, dass eine unzureichende Unterstützung oder unzureichendes Commitment von Führungskräften einen negativen Einfluss auf die Einführung agiler Vorgehensmodelle hat. Weiterhin kann es zu Problemen kommen, wenn die Kultur zu traditionell (ausufernde Planungs- und Kontrollmechanismen), die Organisation zu groß oder logistische Arrangements unzureichend sind. Auf der Ebene Mensch, wird insbesondere ein Mangel an nötigen (agilen) Fähigkeiten wie Projektmanagement-Kompetenzen aber auch effektives Team Work als kritisch angesehen. Außerdem sind der Widerstand von Individuen oder Gruppen sowie eine schlechte Kundenbeziehung hinderlich. Innerhalb der Dimension Prozesse werden beispielsweise ein unklar definierter Projektumfang, 
Projektanforderungen und Projektplanung als problematisch erachtet. Darüber hinaus wird bei der Durchführung agiler Projekte ein unzureichender Mechanismus zur Fortschrittsmessung, eine unklare Rolle des Kunden oder mangelnde Kundenpräsenz als hinderlich betrachtet. Die Dimension Technik beschreibt unter anderem das Fehlen eines vollständigen und korrekten Sets agiler Praktiken sowie unzureichende Werkzeuge. Weniger erforscht ist jedoch, welche spezifischen Herausforderungen für traditionelle Finanzdienstleister bei der Einführung agiler Vorgehensmodelle bestehen. Diese Forschungslücke soll im folgenden Beitrag geschlossen werden.

\section{Methodik}

Der vorliegende Beitrag ist als Fallstudie konzipiert. Der Grund für die Auswahl der Methodik ist, dass dieser Forschungsansatz besonders geeignet ist für i) Forschungsfragen und Forschungsansätze mit einem explorativen Charakter ii) Untersuchungen im Kontext nicht kontrollierter Umgebungen bei denen der Beobachter nur wenig Einfluss auf die Ereignisse hat (im Gegensatz zu beispielsweise Laborversuchen) iii) der Fokus auf gegenwärtige Ereignisse liegt (Yin 2013). Bei der Analyseeinheit handelt es sich um eine große Fondsgesellschaft (siehe Abschnitt 4). Zur Analyse der erhobenen Daten finden Techniken der Grounded-Theory-Methode Anwendung (Glaser et al. 1968) (siehe Abschnitt 3.2).

\subsection{Datenerhebung}

Der Zugang zu dieser Forschungsarbeit war maßgeblich getrieben durch einen regelmäßigen Austausch und vergangene Forschungskooperationen mit dem untersuchten Unternehmen. Das forschungsseitige Interesse dieser Fallstudie ist die kürzlich angefangene Einführung agiler Vorgehensmodelle, neben den existierenden klassischen Vorgehensmodellen des Unternehmens. Die Datenerhebung besteht aus dreizehn, bei dem Unternehmen vor Ort durchgeführten, Interviews (vier Interviewteilnehmer aus der Stakeholder-Gruppe „agil“, welche zum Beispiel eine Scrum Zertifizierung haben. Neun Interviewteilnehmer aus der Stakeholder-Gruppe „klassisch“, die keine bis wenig Erfahrung mit Scrum haben). Die Interviews wurden zur weiteren Analyse transkribiert. Ein Interview dauerte durchschnittlich 64 Minuten, was zu 277 transkribierten Seiten führte. Zusätzlich wurde die Datensammlung durch weitere Sekundärdaten wie zum Beispiel Anweisungen und Prozessmodelle etc., ergänzt. Die unterschiedlichen Datenquellen halfen dabei, das Phänomen 
tiefgreifender zu beleuchten. Alle Daten wurden zur anschließenden Analyse in die Software ATLAS.ti importiert. Vor jedem Interview wurde der zu interviewenden Person eine kurze Einführung über das Forschungsvorhaben gegeben. Die Interviews folgten anhand eines semi-strukturiertem Leitfadens, welcher die nötige Flexibilität bot, um auf den Hintergrund und die Erfahrungswerte eines jeden Interviewpartners individuell einzugehen. Diese Interviewmethode eignet sich grundsätzlich, um tiefergreifend Einblicke zu gewinnen (Charmaz 2006). Die Interviewfragen wurden offen gestellt und Suggestivfragen wurden vermieden, damit Interviewpartner möglichst ausführlich über die Fragen reflektieren konnten. Zum Beispiel: "Welchen Herausforderungen begegnen Sie regelmäßig bei der Durchführung von Projekten”. Wurde eine nicht zufriedenstellende Antwort gegeben, wurden weitere Fragen gestellt wie zum Beispiel: "Warum genau stellt dies eine Herausforderung dar? Was sind mögliche Gründe hierfür?”.

\subsection{Datenanalyse}

Um diese qualitativen Daten zu analysieren, wurden Techniken der Grounded-TheoryMethode angewandt. Für das Kodieren (Auswerten) der Daten wurde die Software ATLAS.ti verwendet. Hierbei wurden die Daten in einem ersten Abstraktionsgrad Satzweise kodiert. Demnach wurden Sätzen gleicher Bedeutung der gleiche Kode zugewiesen. Im zweiten Kodierungsschritt wurden alle bestehenden Kodes zu allgemeineren Konzepten abstrahiert. Hierbei wurden inhaltlich verwandte Kodes zu übergeordneten Kodefamilien gefasst. Während der Datenanalyse offenbarte es sich, dass die Interviewpartner im Kern über bestehende ProjektmanagementRahmenbedingungen und die daraus resultierenden Herausforderungen erzählten, bzw. darüber berichteten, wie sich diese auf agile Vorgehensweisen auswirken. Folgerichtig wurden diese als Kernkategorie der Datenanalyse identifiziert. Dies leitete auch die weitere Datensammlung in die Richtung an. Nach dem GroundedTheory-Prinzip „,all is data“, wurden zusätzlich zu den Interviewdaten auch relevante Dokumente bei der Analyse miteinbezogen. Beispielsweise wurde von mehreren Interviewteilnehmern berichtet, dass das bestehende Projektmanagement-System eine Herausforderung für Einführung agiler Vorgehensmodelle darstellt. Um ein tieferes Verständnis hierfür zu erlangen, komplementierten Dokumente des spezifischen Projektmanagement-Systems des Unternehmens die Analyse. Weitere Dokumente gaben Einsichten zu internen Aufwandschätzungen der Projektleiter, Projektmanagement Tools, Rollen und Gremien, und Unterlagen zum 
Organisationsaufbau. Parallel zu der fokussierten Datensammlung, wurden bestehende Erkenntnissen in der Literatur gesichtet und hierbei abwechselnd Datensammlung und Datenanalyse betrieben. Dieser Prozess wurde wiederholt, bis eine Sättigung erlangt war, das heißt neu erhobene Interviewdaten führten nur noch zu marginalem Erkenntnisgewinn (Charmaz 2006; Glaser et al. 1968; Urquhart 2012).

\section{Trägerorganisation}

Die Untersuchung wurde in einer der größten Fondsgesellschaften Deutschlands durchgeführt. Mit knapp 3000 Mitarbeitern werden über 250 Mrd. Euro Kundengelder in über 4 Millionen Kundendepots verwaltet. Das Unternehmen ist in mehreren europäischen Ländern mit Standorten vertreten. Das Unternehmen ist organisatorisch nach unterschiedlichen Kriterien strukturiert: Kundensegmente (Privatkunden / Institutionelle Kunden), spezielle Anlageformen (beispielsweise Portfoliomanagement / Immobilien) und Querschnittsfunktionen (beispielsweise Infrastruktur) bilden eigene Organisationseinheiten. Die IT-Systeme werden gebündelt in Basissysteme (beispielsweise Computer, Telefon, Rechnungswesen, etc.), Marktsysteme (beispielsweise CRM), Depotsysteme (beispielsweise Führung der Kundendepots), Investmentsysteme (Kauf/Verkauf von Wertpapierpositionen in den Fonds der Fondsgesellschaft). Jede dieser Bündel verfügt über eine eigene, spezialisierte Projektmanagementeinheit, welche wiederum Organisationseinheiten übergreifend Projekte durchführt. Grundsätzlich ist das Unternehmen interessiert, die Projektmanagementprozesse in den verschiedenen Bündeln möglichst gleichartig durchzuführen und hat daher ein übergreifendes Projektmanagement-System etabliert. Dennoch sind einige Teilprozesse auf die Anforderungen des jeweiligen Bündels adaptiert, bzw. werden in unterschiedlichen IT Systemen abgebildet.

Daher entstehen - trotz der Befolgung einer übergreifenden Richtlinie - immer wieder Herausforderungen. Auslöser hierfür sind beispielsweise die Zunahme von bündelübergreifenden Projekten (unter Nutzung unterschiedlicher IT Systeme für Unterstützung der Projektorganisation), die Einführung agiler Methoden in eine bislang eher klassisch orientierte Organisationsstruktur und gleichzeitig Änderungen in der Organisationsstruktur (z.B. eine Veränderung der Fertigungstiefe) in einzelnen Bündeln. Darüber hinaus wird die Branche, in dem das Unternehmen der Fallstudie agiert, im Kontext der digitalen Transformation immer dynamischer und gleichzeitig stellen sich regulatorische Anforderungen, die in immer kürzeren Abständen 
umzusetzen sind. Vor diesem Hintergrund verfolgen die Entscheidungsträger der Organisation das Ziel der Einführung agiler Vorgehensmodelle (auf Basis von Scrum) im Unternehmen. Dies wird ebenfalls von den internen Kunden gefordert und maßgeblich vom Vorstand im Rahmen einer „digitalen Strategie“ vorangetrieben.

\section{Ausgangssituation und Rahmenbedingungen}

Im Folgenden werden die festgestellten Rahmenbedingungen geschildert. Zur Strukturierung wird hierbei auf die bestehenden Dimensionen Organisation, Menschen, Prozesse und Technik aus Kapitel 2 Relevante Grundlagen zurückgegriffen.

Mensch: Verständnis von agilen Vorgehensmodellen. Die Auffassung vieler Interviewpartner ist, dass die Segmente und der Vorstand agile Vorgehensmodelle mit schnelleren Projektergebnissen in Verbindung bringen. So erklärte ein Interviewteilnehmer:

„Man möchte noch schneller sein und ein noch ein besseres time-to-market haben. Außerdem möchte man auch, letztendlich getrieben von einem segmentierten Haus, noch eine weitere Möglichkeit der Einflussnahme während der Projektlaufzeit haben. Das ist eigentlich der Hintergrund, warum man sich mit solchen Punkten [Scrum] beschäftigt."

Auf der Ebene der Projektleiter ergibt sich das Bild, dass die meisten vorgeben, innerhalb ihrer Projekte bereits agil vorgegangen zu sein. Für die Projekte gibt es zwar ein definiertes Projektmanagement-System, es bleibt den Projektleitern jedoch relativ viel Autonomie, wie sie ihr Projekt im Detail organisieren. Ein Interviewpartner schilderte das bisherige Vorgehen bei der Durchführung von Projekten wie folgt:

„Wie genau sie ihr Projekt organisieren, da gibt's nichts. Das können sie machen wie Sie wollen. Ich habe auch schon Projekte agil gemacht, weil das zum Beispiel eine Softwareentwicklung war. Das hat überhaupt keinen interessiert.“

\section{Prozesse: Projektmanagement-System und der Prozess von Einzelprojekten} (vereinfacht, ohne Beachtung der IT-Service-Managementebene). Die Projektmanagementanweisung (von klassischen Projekten) sehen unterschiedliche Phasen und Quality Gates vor. Ein klassisches Projekt hat zwei übergeordnete Gliederungsebenen: Die Vorstudie und die eigentliche Umsetzung des Projektes. Diese sind wiederum in Phasen untergliedert. Die erste Phase ist die Projektinitiierung, welche die Erstellung von Projektunterlagen sowie den Projektstart vorsieht. Am Ende der Phase befindet sich ein Lenkungsausschuss-Beschluss und das erste Quality Gate 
„Projektreife“. Die zweite Phase beschreibt die Projektvorstudie, in der eine Vorstudie gestartet, durchgeführt und abgeschlossen wird. Das Ergebnis ist in der Regel ein (oder mehrere) Fachkonzept(e) und die Planung für die Umsetzung. Diese Phase mündet mit einem Lenkungsausschuss-Beschluss im zweiten Quality Gate „Umsetzungsreife“. In der nächsten Phase wird das Projekt umgesetzt. Hier wird die Umsetzungsplanung kontinuierlich verfeinert, die Umsetzung durchgeführt, integriert bzw. abgenommen und ausgerollt. Wobei zwischen Durchführung und Abnahme das dritte Quality Gate „Testreife“ und zwischen Integration und Abnahme das vierte Quality Gate „Produktionsreife“ steht. In der letzten Phase steht nach dem Rollout der Projektabschluss an. Neben dem fachlich inhaltlichen und kaufmännischen Projektabschluss wird ein Projektabschlussbericht erstellt.

Insgesamt lässt sich feststellen, dass in dem betrachteten Unternehmen die Prozesse sehr formal und unter Einbindung vieler Stakeholder geregelt sind. Dies wird am (bereits vereinfachten) Beispiel einer Projektinitiierung deutlich. Wurde ein Projekt vom Auftraggeber genehmigt, muss die Planung entsprechend erstellt werden, Ressourcen angefordert und genehmigt werden. Es findet ein Workshop statt, damit die Projektziele mit den relevanten Stakeholdern im Detail besprochen und festgehalten werden. Weiterhin gibt es Vertragsvorlagen, die für den jeweiligen Projektebedarf befüllt werden und anschließend nochmal durch verschiedene Abteilungen - wie Einkauf oder Rechtsabteilung geprüft werden müssen. Für Projekte gibt es verschiedene Verifizierungen wie zum Beispiel durch den IT-Security-Officer, den Betriebsrat, den Outsourcing-Beauftragten, die betroffenen IT-ServiceManagement-Beauftragten oder den Datenschutzbeauftragten. Ein Interviewpartner erklärte, dass viele Prozessschritte wiederum Abhängigkeiten aufweisen, welche die Durchlaufzeiten stark beeinflussen können:

„Wenn man das wirklich so leben würde, wie es da drinsteht. Und jemand sagt: Starte das Projekt schnellstmöglich. Dann würde ich drauf wetten, dass sich nicht jeder daran halten würde. Bis eine Verifikation durchgeführt ist, vergehen so vier Monate, bevor überhaupt ein Projekt startet”.

Infolge starten Projekte möglicherweise bevor alle Prozessschritte durchlaufen sind. Damit kann es vorkommen, dass externe Dienstleister Rechnungen stellen und von einem Budget bezahlt werden, welches noch nicht abschließend genehmigt wurde.

Organisation: Ressourcenknappheit und Anzahl der Projekte im Portfolio. Im Unternehmen unserer Fallstudie existiert bei Projekten ein regemäßiger Engpass an Ressourcen. Dies reicht von einer Knappheit an Räumen bis hin zu internen 
Mitarbeitern. Auf der anderen Seite werden aber immer mehr Projekte aufgesetzt, die die zunehmende Regulation und den sich verändernden Markt, insbesondere die Digitalisierung, adressieren. So erklärte ein Interviewpartner:

„Das sind alles so Themen, die waren als ich hier angefangen habe, noch nicht in so einem Maße vorhanden. Gleichzeitig wurde aber nicht gesagt, dass sich etwas an der Anzahl der Projekte ändert, dabei wird einfach alles immer mehr und immer komplexer. Bei uns werden mehr Projekte gemacht als wir von der Kapazität her stemmen können. Sowohl von den Projektleitern, der Fachbereichsressource [Auftraggeber] oder sogar von den Externen [IT-Berater und Entwickler] her".

Dies hat zur Folge, dass bestimmte kritische Ressourcen, wie zum Beispiel das spezielle Wissen von Fachbereichsmitarbeitern, auf das regelmäßig zurückgegriffen werden muss, nicht immer im notwendigem Umfang zur Verfügung steht. Dies liegt daran, dass diese, parallel zur hohen Belastung aus dem Tagesgeschäft, noch in mehreren Projekten eingebunden.

Organisation: Ressourcenplanung Die Zuteilung und die Priorisierung der Ressourcen finden nicht nur am Anfang eines Projektes statt, sondern kontinuierlich auf monatlicher Basis. So schilderte ein Interviewpartner folgendes Problem:

„Wenn ein neues, konkurrierendes Projekt gestattet wird, das in der Priorisierung höher eingeordnet ist, dann kann es passieren, dass ich ein MillionenProjekt am Laufen habe und jetzt werden mir Ressourcen weggenommen."

Organisation: Ressource Räumlichkeiten. Für das Unternehmen besteht ebenfalls ein Engpass bezüglich der ausreichenden Verfügbarkeit räumlicher Ressourcen. So ist es oft schwierig, einen dedizierten Projektraum zu reservieren, in dem alle Projektmitarbeiter eingeladen werden können. Hierzu berichtete ein Interviewpartner:

„Ich glaube, dass man für Projekte sinnvollerweise auch einen Projektraum haben sollte, in dem man sich mal trifft, [...] dass man irgendwo einen Raum hat, in den man sich auch Probleme diskutieren kann."

Mensch: Projektleiterkapazität und Tätigkeiten. Durch eine große Anzahl an Projekten im Portfolio bei gleichzeitig knapp bemessenen Ressourcen verantwortet jeder Projektleiter im Durchschnitt drei Projekte. Abzüglich weiterer Aktivitäten wie der Teilnahme an Sitzungen, Weiterbildungen etc. und einem Urlaubsanspruch, verbleibt einem Projektleiter damit ca. ein Tag in der Woche pro Projekt. Weiterhin werden für jedes dieser Projekte auch administrative Tätigkeiten von Projektleitern übernommen. In den Aufgabenbereich eines Projektleiters gehören zum Beispiel das Schreiben und die Abstimmung von Verträgen mit externen Dienstleistern, wie Softwareherstellern oder auch Marktdaten-Lieferanten. Zusätzlich fungieren 
Projektleiter als Vermittler zwischen strategischem Einkauf und Rechtsabteilung, sollten vertragliche Anmerkungen entstehen. Eine weitere administrative Tätigkeit ist die Buchhaltung in Projekten. Für sämtliche Ausgaben eines Projektes muss die Kostenart mit dem entsprechenden Verteilungsschlüssel und Steuersatz des jeweiligen Landes gebucht werden (im Falle mehrerer und/oder internationaler Auftraggeber (siehe 4. Trägerorganisation). So erklärte ein Interviewpartner:

„Damit verbringe ich relativ viel Zeit, obwohl es nicht sein müsste. Meine eigentliche Aufgabe - das Projekt zu leiten, die Mitarbeiter zu leiten, das Ganze zu managen und vor allem die Kommunikation - fällt hinten runter. Das erzeugt bei mir und dem Kunden oft Unzufriedenheit, denn mit ihm rede ich eigentlich viel zu wenig.“

\section{Herausforderungen für die Einführung agiler Vorgehensmodelle}

Anhand der Rahmenbedingungen des vorherigen Kapitels werden in diesem Kapitel die Herausforderungen für die Einführung agiler Vorgehensmodelle aufgezeigt. Hierbei handelt es sich um bereits, die die Rahmenbedingungen mit sich bringen.

Mensch: Verständnis von agilen Vorgehensmodellen. Während der Vorstand und die Segmente eine agile Vorgehensweise fordern, sind hiermit auch bestimmte Bedingungen verknüpft. So erklärte uns ein Interviewpartner, dass ein Bewusstsein notwendig ist, was agile Vorgehensmodelle sind und welche Implikationen diese auf Projektebene haben:

„[...] aber es ist nur eine Methode ein Projekt durchzuführen. Dem Vorstand und den Segmenten ist aber nicht so bewusst was es bedeutet. [...] Wie schon mehrfach erwähnt, muss man zum Beispiel für den Erfolg eines agilen Projektes, Ressourcen zu einem gewissen Prozentsatz zur Verfügung stellen. “

Demnach reicht nicht nur das Commitment des Top Managements, diese Vorgehensmodelle einzuführen, sondern es muss auch das Bewusstsein vorhanden sein, welche Rahmenbedingungen hierfür geschaffen werden müssen. Hier ergibt sich gerade bei traditionellen Unternehmen, welche eher klassische Projektmanagementansätze unterstützen, die Notwendigkeit, dieses Bewusstsein institutionell zu verankern. Weiterhin besteht die Herausforderung des Schaffens eines Bewusstseins über agile Vorgehensmodelle auch auf der Ebene der Projektleiter: agil]."

„Also ich sehe da nicht so einen riesen Unterschied [zwischen klassisch und 
Ein möglicher Grund hierfür ist, dass die Rahmenbedingungen des Unternehmens nur bedingt für agile Vorgehensmodelle geeignet sind. Ein weiterer Interviewpartner bestätigt:

„So wie wir es hier bei uns im Hause tun [agiles Vorgehen], kann man es auch mit herkömmlichen Projekt-Management-Methoden machen. “

\section{Prozesse: Projektmanagement-System und der Prozess von Einzelprojekten} (vereinfacht, ohne Beachtung der IT-Service-Managementebene). Die Richtlinien und Vorgaben zur Durchführung von klassischen Projekten sehen einen sequenziellen Ablauf von Phasen und Quality Gates vor. Diese sind für klassische Projekte geeignet, für agile Vorgehensmodelle stellen sie eine Herausforderung dar. Zum Beispiel Quality Gate 3 „Testreife“, bei dem zuerst etwas fertig entwickelt wird und anschließend getestet wird, ist auf klassische Vorgehensmodelle ausgerichtet. Agile Vorgehensmodelle hingegen sehen einen sehr viel feiner iterativ, inkrementellen Ansatz vor. Weiterhin trennen agile Projekte nicht zwischen Vorstudie und Umsetzung, sondern das Projekt wird sukzessive in sogenannten Sprints (ein Inkrement eines Projektes) umgesetzt. Somit sind die bestehenden Richtlinien und Vorgaben für die Vorgehensweise klassischer Projekte nicht auf agile Projekte übertragbar, ohne dass es zu Friktionen kommen würde. Insbesondere die fundamentale Annahme agiler Vorgehensmodelle, in der stetige Verbesserung durch Feedback und Tests herbeigeführt wird, steht möglicherweise im Widerspruch zur initialen, sehr viel statischeren Zieldefinition einer vorgelagerten Vorstudie. Insgesamt lässt sich feststellen, dass sich die historisch gewachsene Organisationskultur der prozess-zentrischen Kontrolle und formalen Kommunikation nur bedingt mit agilen Vorgehensmodellen vereinbaren lassen. Agile Vorgehensmodelle, die diese Prozesse des bereits bestehenden Projektmanagement-Systems wie die Erstellung einer Vorstudie, Budgetfestlegung und Freigabe ebenfalls verfolgen müssen, sind bestenfalls als eine Mischform aus traditionellen und agilen Vorgehensmodell zu betrachten. Eine gesamtheitliche Anpassung der Abhängigkeiten zu anderen Abteilungen wäre erforderlich, um agile Vorgehensmodelle einzuführen, was folgendes Zitat verdeutlicht:

„Man geht nicht mit dem ganzen Unternehmen diesen Schritt, sondern eigentlich nur mit einem Teil des Projektmanagements, mit einzelnen Projekten. Deshalb passen die Prozesse einfach nur bedingt. “

Organisation: Ressourcenknappheit und Anzahl der Projekte im Portfolio; Planung und Räumlichkeiten. Agile Vorgehensmodelle zielen auf ein sich selbst 
organisierendes Team ab, bei dem Ressourcen verbindlicher als bei der klassischen Vorgehensweise zur Verfügung gestellt werden sollten. Beispielsweise sind tägliche Meetings („Daily Scrum Meeting“) vorgesehen. Für erfolgskritische Ressourcen, wie Fachbereichsmitarbeiter, die lediglich wenige Tage in der Woche zur Verfügung stehen, ist dies ein zu lösendes Spannungsfeld. Zusätzlich birgt der dynamische, monatliche Ressourcenplanungsprozess die Gefahr, dass genehmigte Ressourcen auch nachträglich aus agilen Teams abgezogen werden können, was folgendes Zitat aufzeigt: “Auf der einen Seite möchte man alles planen und die Ressourcen optimal nutzen, aber auf der anderen Seite möchte man auch die Personen verbindlich in agilen Projekten haben, bzw. wenn man weiß, es kommen neue Anforderungen rein und man braucht die [Personen] länger, dass die dann auch weiterhin für die Projekte zur Verfügung stehen.“ Für agile Projekte ist es weiterhin von Vorteil, auf einen dedizierten Projektraum zugreifen zu können. Dies wirkt sich zum Beispiel positiv auf die informelle Kommunikation und den Projekterfolg aus (Hummel et al. 2013). Angesichts der begrenzten Verfügbarkeit von Räumen im Unternehmen kann dies ebenfalls als Herausforderung gewertet werden, erklärt ein Interviewpartner:

„Die Idee [bezieht sich auf agile Vorgehensmodelle], dass die Leute praktisch in einem Raum sitzen und die ganze Zeit zusammen sind, dass lässt sich hier ja gar nicht umsetzen. “

Mensch: Projektleiterkapazität und Tätigkeiten. Weiterhin sind die administrativen Tätigkeiten, sowie die Anzahl der Projekte der Projektleiter nur bedingt mit den Rollen von Scrum vereinbar (Product Owner, Scrum Master und Entwickler-Team). Ferner wird im betrachteten Unternehmen bei einem klassischen Projekt der Projektleiter von der IT-Abteilung gestellt. Scrum sieht jedoch vor, dass der Product Owner, welcher im Fachbereich angesiedelt ist, diese Verantwortung übernimmt. Zusammen mit der Verantwortung müssten somit auch die weiteren Tätigkeiten, welche ein klassischer Projektleiters zu erfüllen hat, auf den Product Owner übergehen. Demnach ist die Frage zu klären, welche Tätigkeiten, sowie Rechte und Pflichten wie auf das agile Vorgehensmodell übertragen werden.

\section{$7 \quad$ Fazit}

Zusammenfassend lässt sich festhalten, dass sich das Unternehmensumfeld traditioneller Finanzdienstleister in den letzten Jahren fundamental geändert hat. Die ehemals relativ stabile Ausgangslage hat sich hin zu dynamischen Marktbedingungen 
bewegt, welche insbesondere geprägt sind durch die Finanzkrise, zunehmende Anforderungen durch eine strenge Regulation, das sich ändernde Kundenverhalten, neue Wettbewerber (zum Beispiel FinTechs) und schließlich dem Phänomen der Digitalisierung in der Finanzwirtschaft. In diesem dynamischen Umfeld werden agile Vorgehensmodelle immer beliebter, weil Sie als ein Lösungsansatz wahrgenommen werden und den Erhalt der Wettbewerbsfähigkeit sichern sollen. In etablierten Unternehmen mit historisch gewachsenen Strukturen und gegebenen Rahmenbedingungen (siehe Tabelle 6) werden traditionell eher klassische Vorgehensmodelle eingesetzt (wie in der Fondsgesellschaft dieser Fallstudie). In diesen Umgebungen stellt es eine grundlegende Herausforderung dar, agile Vorgehensmodelle einzuführen. Die vorliegende Studie zeigt exemplarisch, dass die identifizieren Herausforderungen insbesondere bei den Dimensionen Organisation, Mensch und Prozesse liegen. Die Herausforderung ,Ressourcen` lässt sich als eine Ausprägung der Dimension Organisation identifizieren, wobei Ressourcen ebenfalls als bestehendes Problem für jedes (klassisch und agil) Projekt in der Organisation gewertet werden können. Die Herausforderung ,Projektleiterkapazität und Tätigkeiten‘ lässt sich der Dimension allgemeineres Problem zu bezeichnen, welche auch klassisch Projekte betrifft. Bei der Einführung agiler Vorgehensmodelle ist zu beachten, dass die nötigen Kompetenzen zuerst aufgebaut werden müssen und insgesamt höhere Ansprüche an die Projektleiter und die Organisation stellen. Beispielsweise müssen künftig Kompetenzen für beide Vorgehensmodelle, agil und klassisch, vorgehalten werden, weil sich manche Projekte eher für eine agile andere wiederum eher für eine klassische Vorgehensweise eignen. Das ,Projektmanagement System und Prozess von Einzelprojekten` ordnet sich in die Dimension Prozesse ein. Diese Herausforderung ist als agil-spezifisch zu bezeichnen. Etablierte Organisationen in der Regel ein bestehendes Projektmanagement-System und in der Fallstudie wird aufgezeigt, dass ein bisher nur auf klassische Projekte ausgerichtetes Projektmanagement-System nicht geeignet ist für die Einführung agiler Vorgehensmodelle. Vor dem Hintergrund einer erfolgreichen Verankerung agiler Vorgehensmodelle müssen diese historisch gewachsenen Strukturen aufwendig angepasst werden -im Gegensatz zu beispielsweise relativ neue Unternehmen wie FinTechs, welche solche Strukturen noch nicht in diesem Umfang und Ausmaß aufweisen. Die Herausforderung, Verständnis über agile Vorgehensmodelle‘ ist ebenfalls eine agil-spezifische Ausprägung. Es ist wichtig, ein grundlegendes Verständnis darüber zu haben, was agile Vorgehensmodelle sind und für welche Arten 
von Projekten diese sich eignen. Innerhalb der Organisation muss ein Verständnis dafür herrschen, welche notwendigen Voraussetzungen für agile Vorgehensmodelle existieren müssen, damit diese erfolgreich eingeführt und in Projekten umgesetzt werden können. Für etablierte Organisationen besteht hierbei zusätzlich die Herausforderung, dass eine etablierte Unternehmenskultur existiert bzw. Mitarbeiter es gewohnt sind auf eine bestimmte Art und Weise Projekte durchzuführen. Die nachstehende Tabelle fasst die Herausforderungen entlang der Dimensionen zusammen und zeigt dabei auf, ob die Herausforderungen globaler Natur sind oder spezifisch für agile Vorgehensmodelle.

\begin{tabular}{llll}
$\begin{array}{l}\text { Dimension/ } \\
\text { Herausforderung }\end{array}$ & Organisation & Prozesse & Mensch \\
Ressourcen & Klassisch/Agil & & \\
$\begin{array}{l}\text { Projektleiter } \\
\text { Tätigkeiten und }\end{array}$ & & & Klassisch/Agil \\
Kapazitäten & & & \\
PM-System & & Agil & \\
Verständnis & & & Agil \\
\hline
\end{tabular}

Table 7: Zusammenfassung der Ergebnisse.

Abschließend lässt sich festhalten, dass der Beitrag neben der wissenschaftlichen Relevanz, die Identifizierung der Rahmenbedingungen und dessen abgeleitete Herausforderungen für die Einführung agiler Vorgehensmodelle, die Ergebnisse ebenfalls von praktischer Relevanz sind. So lassen sich die Ergebnisse für traditionelle Finanzdienstleister mit einer ähnlichen Ausgangslage verallgemeinern, bei denen vergleichbare Strukturen und Rahmenbedingungen vorliegen. Dieses Bewusstsein über die Rahmenbedingungen und dessen Implikationen sind ein notwendiges Kriterium für das Entwickeln möglicher Lösungsansätze.

\section{Praktische Handlungsempfehlungen}

Die folgenden Handlungsempfehlungen wurden aus den transkribierten und kodierten qualitativen Primär- und Sekundärdaten abgeleitet.

Workshops und Informationsveranstaltungen: Die Durchführung von Workshops und Informationsveranstaltungen sind dienlich, um ein Verständnis agiler Vorgehensmodelle aufzubauen bzw. dieses zu erweitern. Weiterhin dienen diese der Aufklärungsarbeit, um zu vermitteln was agile Vorgehensmodelle für das Unternehmen bedeuten und welche Rahmenbedingungen erfolgskritisch sind. So kann 
hier bereits ein Problembewusstsein geschaffen werden, dass kurze Prozessdurchlaufzeiten, Ressourcen etc. zur Verfügung stehen müssen.

Rahmenbedingungen für Agil: Neben der Kommunikation durch Workshops und Informationsveranstaltungen, müssen agile Vorgehensweisen auch in den (internen) Richtlinien und Vorgaben festgehalten werden bzw. die bestehenden Richtlinien und Vorgaben für klassische Vorgehensmodelle bzgl. agiler Vorgehensmodelle angepasst werden. Inhaltlich betrifft dies zum Beispiel die Anpassung der Quality Gates, die Aufnahme von Scrum Praktiken wie Sprints aber auch die verbindliche Zusage von Ressourcen für agile Projekte (aus Interviews, Entwurf einer neuen Richtlinie). Insgesamt werden somit die Rahmenbedingungen geschafften sowie organisationsweit einheitlich und sichergestellt, was unter agilen Vorgehensmodellen verstanden wird. Um den Engpass an Ressourcen zu minimieren, sind weniger kurze Projekte als viele lange, die parallel laufen, und/oder die Investition in kritische Ressourcen förderlich.

Methoden und Schulungen: Das Aufbauen von Kompetenzen, und Schulungen für beispielsweise Schlüsselrollen agiler Vorgehensweisen (Scrum Master, Product Owner) sind essentiell für den Einsatz agiler Vorgehensmodelle im Unternehmen. Viele Mitarbeiter gaben an, bereits inkrementell und/oder agil vorgegangen zu sein, soweit es die bisherigen „klassischen Rahmenbedingungen“ ermöglichten. Hier muss angesetzt und die Methodenkompetenzen weiterentwickelt werden. So gaben fast alle Interviewteilnehmer an, dass eine Weiterbildung bzgl. agilen Vorgehensmodellen sinnvoll und wünschenswert ist.

\section{$9 \quad$ Limitationen und künftige Forschung}

Die der Studie zu Grunde liegenden Primärdaten (Interviews) stammen aus dem Bereich des IT-Projektmanagements und hauptsächlich aus einem Segment des Unternehmens. Künftige Forschung zielt darauf ab, auch den Fachbereich des Fallstudienunternehmens einzubeziehen, um einen weiteren Betrachtungswinkel zu integrieren. Künftige Forschung wird darauf abzielen, den Einführungsprozess agiler Vorgehensmodelle weiter $\mathrm{zu}$ begleiten und Lösungswege für die gefundenen Herausforderungen zu identifizieren und konzeptualisieren. 


\section{Digital Business Models}

The second research area II. Digital Business Models highlights the enabling role of digital technologies towards new digital business models (Fichman et al. 2014). This corresponding research questions, as stated in the foundation part of this theses, are:

RQ II.1: What dimensions and characteristics exist for digital business models in the financial services industry?

RQ II.2: What are typical innovative digital business models in the financial services industry? 


\title{
II.1. Digital Business Models: FinTech Business Model Taxonomy
}

\author{
What do FinTechs actually do? \\ A Taxonomy of FinTech Business Models
}

Abstract: FinTechs are companies that combine technological and financial attributes in their business models. In recent years, the rise of FinTechs has attracted much attention since they challenge incumbent financial service companies including the traditional banking model. In this paper, we aim to contribute to a better understanding of this phenomenon. Therefore, we develop a taxonomy of FinTech business models following a theoretically grounded and empirically validated approach for identifying and defining underlying business model elements. After developing our taxonomy, we use a clustering-based approach to identify business model archetypes on which to showcase our results, re-examine the assumptions made during taxonomy development, and validate the presented findings. Based on the gained insights, we discuss implications for research, practice and policy makers, as well as directions for future research.

Outlet: Eickhoff, M., Muntermann, J., and Weinrich, T. 2017. "What Do Fintechs Actually Do? A Taxonomy of Fintech Business Models," Proceedings of the International Conference on Information Systems 2017, Seoul, South Korea, pp. 1-19.

Keywords: Taxonomy, E-finance, FinTech, digital business model, digital transformation, financial technology 


\section{Introduction}

The financial services industry has always been characterized by a high affinity towards the use of information technology (IT). Eventually, this has led to an inextricable interlocking of the financial services industry and IT. However, in the past, IT was primarily a driver for cost-effectiveness and efficiency gains, like the automation of processes. Exemplarily, financial transactions are completed without any physical interaction (Puschmann 2017). More recently, the role of IT in general is undergoing a fundamental shift. Digital transformation of whole industries is brought about by pervasive digital technologies (El Sawy and Pereira 2013; Lucas Jr et al. 2013). According to this new understanding of IT, companies create and capture “[...] business value that is embodied in or enabled by IT” (Fichman et al. 2014). This transformational impact can also be witnessed in the financial services industry via the emergence of new business models such as "robo-advisors", and an increasing crossindustry competition with formerly pure technology companies entering the financial market, such as Apple (Puschmann 2017). In sum, the emergence of pervasive digital technology (collectively referring to mobile technologies, cloud computing, big data analytics and social media) (Bharadwaj et al. 2013) triggered a shift in the role of technology, moving beyond process automation towards the enabling role of new innovative (digital) business models (Fichman et al. 2014; Teece 2010).

This development collectively refers to the movement of FinTechs. The term FinTech stems from the words financial and technology and clearly indicates the markets in which these companies do their business. Yet, due to the relatively recent emergence of FinTechs, there is no distinct agreement on or definition of what a FinTech actually is. Recent contributions describe FinTechs broadly as an entrepreneurial phenomenon in the financial services industry that leverages digital technologies. For example, Arner et al. (2015, p. 3) define FinTechs as companies that use "[...] technology to deliver financial solutions,” and they are similarly described by Lee and Teo (2015) as companies offering"[...] innovative financial services or products delivered via technology." FinTechs are also accounted for challenging established roles, business models and service offerings in the financial sector, which is particularly caused by the introduction of technology-based innovations (Gomber et al. 2017). These aspects are covered by the definition of Sia et al. (2016, p. 105) who define FinTechs as " $a$ new generation of financial technology start-ups that are revolutionizing the financial 
industry” and by Puschmann (2017, p. 74), who define them as "[...] incremental or disruptive innovations in or in the context of the financial services industry induced by IT developments resulting in new intra- or inter-organizational business models, products and services, organizations, processes and systems." Against this background, we use the following definition in this paper: FinTechs are companies that operate at the intersection of (i) financial products and services and (ii) information technology, they are usually (iii) relatively new companies (often startups) with (iv) their own innovative product or service offerings.

As digital technologies impact society at large and customers become increasingly technology-savvy, they can easily draw on ubiquitous, readily available information. As a result, customers are more informed, demand a higher level of transparency related to products and services, and are shifting their expectations towards more diverse yet personalized offerings (Alt and Puschmann 2012; Granados and Gupta 2013; Hansen and Sia 2015; Hedley et al. 2006). This development is a major driver of FinTech success and it explains why FinTechs hold the potential to disrupt whole branches of the financial services industry: FinTechs are often able to understand their customers better than incumbents and thus address their needs more effectively (Mackenzie 2015).

Incumbents' actions are often constrained by legacy systems, resulting in tension and the need to transform and adapt to digital technologies (Gregory et al. 2015) while also meeting institutional expectations from, e.g., regulators and analysts (Benner and Ranganathan 2012; Benner and Ranganathan 2013). In addition to a decline in customers' trust, many traditional financial services companies are affected by stricter regulations as a consequence of the financial and EURO crises (Alt and Puschmann 2012). In contrast, FinTechs are apparently less affected by these developments and the opposite seems to be the case: regulators seem to struggle to keep up with the ongoing increase in the diffusion and adoption of digital technologies alongside the creation of new innovative businesses (McGrath 2013; Rycroft 2006), resulting in a “pacing problem” (Marchant 2011).

However, we also see that incumbents started to cooperate with FinTechs for value creation, leading to new ecosystem setups. In sum, the rise of FinTechs is an important and relatively new phenomenon, which addresses the changing role of IT, changing customer behavior, changing ecosystems, and changing regulation in the financial 
services industry (Puschmann 2017). Given this new enabling role of IT for business value creation in the financial industry, it is important to understand the similarities and differences among different business models in the FinTech field. The business model concept is useful for developing such an understanding as it provides “[...] $a$ conceptual tool that contains a set of elements and their relationships and allows expressing the business logic of a specific firm" and "[...] a description of the value a company offers to one or several segments of customers and of the architecture of the firm and its network of partners for creating marketing, and delivering this value and relationship capital, to generate profitable and sustainable revenue streams" Osterwalder et al. (2005, p. 17). Against this background, we aim at providing a rigorous overview of FinTech business models. Thereby, this paper contributes to a better understanding of FinTech business models by answering the following research question:

RQ1: What are the theoretically grounded and empirically validated elements of financial technology companies’ (FinTech) business models?

RQ2: Which FinTech business model archetypes can be identified by an empirical examination of these elements?

To answer these questions, we first develop a taxonomy of FinTech business models (RQ1), before applying this taxonomy to our sample of FinTech companies using cluster analysis (RQ2), which yields a sample of companies, for which we investigate whether typical patterns (archetypes) of business model elements can be identified.

\section{Theoretical Background}

\subsection{Classification Systems and Taxonomies}

Maybe one of the earliest and best known publications of a classification system goes back to the botanist, physician, and zoologist Carl Linnaeus who, amongst other important classification schemes, published the "Systema Naturae” in 1758 providing a comprehensive classification of species of animals and plants (Linnæus 1735). Since then, the need for ordering or classification of objects and phenomenon of interest has been recognized as a fundamental form of science in most scientific disciplines as it aims at organizing concepts of knowledge (Carper and Snizek 1980). Classification systems put structure to a field of knowledge and can help researchers in further theory 
developing when hypothesizing and studying relationships among described objects. They are useful to e.g., explain differences and similarities of objects, as well as uncovering and classifying non-existent objects (Glass and Vessey 1995; Varshney et al. 2015). In the IS field, classification systems and taxonomies have themselves been classified as "theory for analyzing" describing characteristics of objects or phenomenon and relationships between them (Gregor 2006).

As reported by Nickerson et al. (2013), in IS research the term "taxonomy" is widespread, and the authors define it as a "set of dimensions each consisting of a set of mutually exclusive and collective exhaustive characteristics” (Nickerson et al. 2013, p. 340), or more formally as follows:

$$
\mathrm{T}=\left\{\mathrm{D}_{\mathrm{i}}, \mathrm{i}=1, \ldots, \mathrm{n} \mid \mathrm{D}_{\mathrm{i}}=\left\{\mathrm{C}_{\mathrm{ij}}, \mathrm{j}=1, \ldots, \mathrm{k}_{\mathrm{i}}, \mathrm{k}_{\mathrm{i}} \geq 2\right\}\right\}
$$

$D_{i}(i=1, \ldots, n)$ defines the $n$ dimensions and $C_{i j}\left(j=1, \ldots, k_{i}\right) k_{i}\left(k_{i} \geq 2\right)$ the mutually exclusive and collectively exhaustive characteristics $C_{i j}\left(j=1, \ldots, k_{i}\right)$ each dimension consists of. Here, "mutually exclusive” refers to the property that no object has two different characteristics in a dimension, while "collectively exhaustive" is used when each object has at least one characteristic in each dimension. Together, these two properties assure that each object has exactly one characteristic in each single dimension. We use this definition in the formal presentation of the developed taxonomy.

\subsection{Conceptualizations of Business Models}

In a recent review of the business model literature, Zott et al. (2011) found that the scholarly discourse is very heterogeneous in regard to the question of "what is a business model?”. Generally, articles on business models refer to them as presentations of building blocks. However, they often lack a clear definition of the business model concept. Yet, Zott et al. (2011) show that the existing literature on business models can be classified according to three generic themes: 1) e-business models where organizations make use of information technology; 2) strategic issues, which address competitive advantage, value creation, and firm performance; and 3) the management of innovation and technology (Zott et al. 2011). For logic reasons, we focus on 1) ebusiness models, which suits our taxonomy development of FinTech business models and includes the following contributions (Alt and Zimmermann 2001; Osterwalder et al. 2005). 
Another extensive review of the business model literature is presented by Alt and Zimmermann (2001), who find six common elements that business models consist of: mission, structure, processes, revenues, legal issues, and technology. The mission is described as one of the more important elements of a business model. It encompasses an understanding ranging from corporate strategy down to products and services, including the value proposition. In addition, a convincing business model is often led by a vision and not just by the technology behind it. Structure highlights the actors and governance a company is engaging, i.e., its value network. Furthermore, it also describes the company's geographic and industry focus. Processes can be viewed as a more granular look at a business model's mission and structure, which provides detailed insight into the activities of value creation, i.e., customer orientation as well as coordination mechanisms. Revenues define the business' logic and sources of its revenue. Legal issues are an element that touches all dimensions: potentially influencing the vision, structure, value creation processes, and revenue model. Finally, technology can be an enabler of but also a constraint on a (technological) business model. Like legal issues, technological developments may influence the mission, structures, processes, and revenue model of a company.

Osterwalder et al. (2005, p. 12) identify nine common business model elements: value proposition, target customer, distribution channel, relationship, value configuration, core competency, partner network, cost structure, and revenue model. Value propositions provide information on what products and services a company is offering. Target customer describes to whom the company intends to offer its products and services, i.e., the value; distribution channels are the means and ways of how a company reaches out to its customers; and relationship refers to the links a company creates between its target customers and itself. These three elements (target customer, distribution channel, relationship) can also be subsumed under customer interface. Value configuration is how resources are arranged in relation to a company's activities; core competencies highlight the competencies that are needed to carry out the (desired) business model; and partner networks are the company's cooperation with other actors that are needed to create and offer the value. Value configuration, core competency and partner network can be categorized further as infrastructure management. Finally, the last two elements of a business model highlight financial aspects. The cost structure describes the "monetary consequences" for a business model to operate, and 
the revenue model is the way the company receives money from its revenue streams (Osterwalder et al. 2005).

Practically oriented contributions already capture the categorization schemes of FinTechs (Bajorat 2016; Levy 2015). However, they regularly lack a rigorous methodological foundation and fall short of describing more than one dimension (usually limited to the product/service offering). But also scientific literature on FinTechs in general and especially related to their business models are still scarce (Puschmann 2017).

\section{Methodological Approach to Taxonomy Development}

To address our first research question RQ1, we follow the method presented by Nickerson et al. (2013), which has also been adopted by a number of other IS studies, such as Prat et al. (2015) and Tan et al. (2016). The chosen method provides a structured process for developing taxonomies on the basis of existing theoretical foundations (deduction), as well as empirical evidence (induction) in an iterative manner. In so doing, we build upon the rich business model literature and conceptually derive the taxonomy's dimensions. Then, related characteristics are subsequently developed by empirically examining a large number of globally diverse FinTech companies. The development of taxonomies usually focusses on a specific phenomenon of interest, i.e., a meta characteristic, which is determined at the beginning of the process. All dimensions and characteristics are based on the meta characteristic.

As Nickerson et al. (2013) explain, a taxonomy can be viewed as useful when it meets the following five criteria, representing ending conditions during the iterative process of taxonomy development: (1) the number of dimensions and characteristics should be limited to obtain a concise taxonomy that is easy to apply and comprehend. (2) Yet, to make objects distinguishable from each other, there should be a sufficient number of dimensions and characteristics, making the taxonomy robust. (3) If all relevant dimensions of an object are identified, i.e., if all (or a random sample) can be classified, the taxonomy is comprehensive. (4) The taxonomy's dimensions and characteristics should also be extendable to account for possible new objects in the future that may 
not fit in the existing taxonomy. (5) And finally, to understand the objects, the taxonomy should be explanatory and not just descriptive.

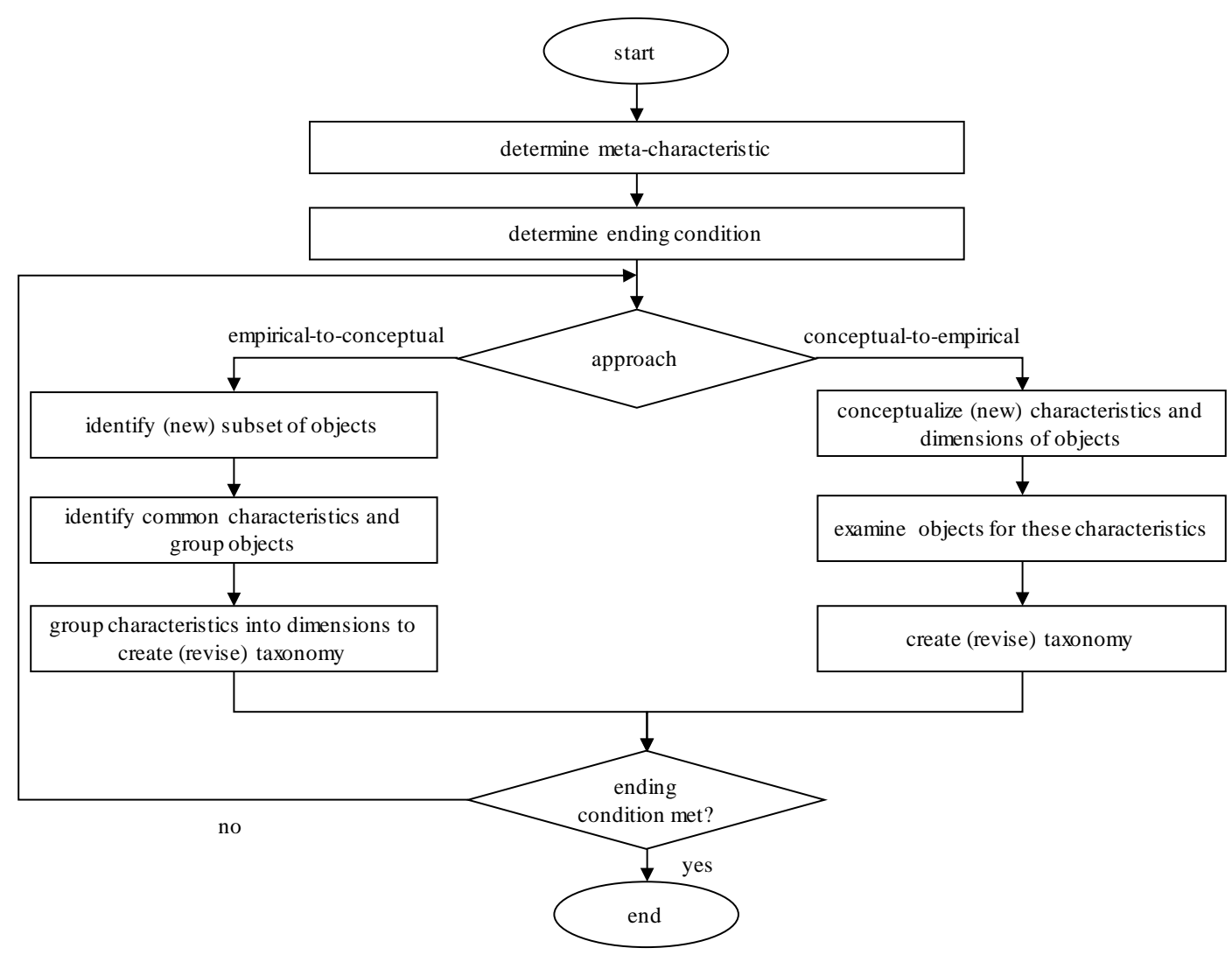

Figure 3: Taxonomy development method (Nickerson et al. 2013, p. 345).

These five attributes are also known as subjective ending conditions of a taxonomy development process. Objective ending conditions are as follows: there is no variation (merge, split or new additions) of objects, dimensions or characteristics in the last iteration; all objects (or a representative sample) are analyzed; every dimension, characteristic within the dimensions and combination of characteristics are unique; there is at least one object categorized for each characteristic under its dimension.

The final taxonomy should satisfy both subjective and objective ending conditions as well as the initial given definition of a taxonomy. During taxonomy development and after each iteration of revising dimensions and/or characteristics of the taxonomy, the satisfaction of all ending conditions is checked. Only if all ending conditions are satisfied, the process of taxonomy development is completed. Following and documenting this structured approach helps to cope with the complexity inherent to taxonomy development and to communicate the resulting taxonomy in a reproducible manner. During each iteration, dimensions and/or characteristics of the taxonomy are 
revised on the basis of either deductive (conceptual-to-empirical) or inductive (empirical-to-conceptual) reasoning.

Doing so allows to build upon existing theoretical foundations or, alternatively, empirical evidence. An overview of all steps of the method suggested by Nickerson et al. (2013) is depicted in Figure 3. In our process of taxonomy development presented in the following section it took four iterations (one conceptual-to-empirical and three empirical-to-conceptual) to arrive at a final taxonomy fulfilling the objective and subjective ending conditions.

\section{Taxonomy Development}

\subsection{Dataset Description}

During empirical-to-conceptual development iterations, we made use of the Crunchbase database (Crunchbase 2016). Crunchbase is a company information database with a focus on the start-up community. The database offers profiles of companies, investors and incubators, individuals, and events, as well as the relationships between these entities. There are two ways to browse the information available on Crunchbase. First, a web interface can be used to view information interactively. Second, an application programming interface (API) is available to perform structured requests against the database. We use the latter as our primary source of data.

Within the Crunchbase database, each company is assigned a number of attributes (tags), which help users to assess companies or find firms with specific characteristics. For our purposes, we use this tag attribute to request all firms in the database that have the "FinTech" tag. This results in a preliminary list of 2,340 companies. For each company, the database contains information such as name, country and city of origin, a hyperlink to the company website, social media links, a founding, date, and a textual description of the company.

We drop all companies for which no URL or textual description is available to exclude companies for which no meaningful information is readily available, resulting in 2,040 companies as the basis for our analysis. During the course of our analysis, more companies are dropped for similar reasons. As expected when looking at an industry dominated by startups, many FinTechs are quickly bought, or they cease operations, 
resulting in unreachable websites or redirects to new parent companies. When this is the case, the company is dropped from the sample. Table 8 provides an overview of the regional distribution of our initial sample. As shown, most companies are located in the United States or the European Union; however, we do not limit the analysis to these centers of activity.

\section{Per country FinTech No. in dataset (countries with at least 4 FinTechs)}

\begin{tabular}{llllllll} 
United States & 942 & Spain & 15 & Canada & 28 & Czech Republic & 7 \\
United & 192 & Ireland & 12 & Mexico & 28 & Italy & 7 \\
Kingdom & 50 & Japan & 12 & Switzerland & 25 & Ukraine & 7 \\
Germany & 50 & South Africa & 11 & Netherlands & 23 & Thailand & 6 \\
India & 40 & Belgium & 10 & China & 22 & Latvia & 5 \\
Australia & 38 & South Korea & 10 & Hong Kong & 21 & Luxembourg & 5 \\
Singapore & 38 & Poland & 9 & Brazil & 18 & Philippines & 6 \\
France & 33 & Indonesia & 8 & Russia & 16 & Malta & 4 \\
Israel & 29 & & & & & & \\
\hline
\end{tabular}

Table 8: Companies coded by country of origin. Only countries with $>3$ companies in the sample are reported in the table to save space, along with their color-coded (by country) global distribution (all observations).

\subsection{Meta Characteristic}

For our taxonomy, we are interested in the business models implemented by FinTechs. In line with (Nickerson et al. 2013, p. 343) the selection of our meta characteristic was guided by the purpose of the taxonomy and it was also based on existing (business model) theory. Consequently, we specify elements of FinTech business models as our meta-characteristic. 


\section{$4.3 \quad \mathbf{1}^{\text {st }}$ Iteration}

Building upon the rich amount of literature on business models, our first iteration involved following the conceptual-to-empirical path of the applied method and, consequently, reviewing the existing knowledge and identifying relevant key concepts from the literature. In doing so, we purposefully selected dimensions that are useful for taxonomy development. We drop possible dimensions, in which many FinTechs are similar or regarding which information about individual companies can be obtained. Specifically, we draw on Zott et al. (2011) and, for the first iteration, we purposefully select $D_{1}=$ Dominant Technology Component and $D_{5}=$ Revenue from Alt and Zimmermann (2001) and $D_{2}=$ Value Proposition, $D_{3}=$ Delivery Channel, $D_{4}=$ Customer Segments, and $D_{5}=$ Revenue Stream from Osterwalder et al. (2005), which led to a preliminary taxonomy with the following formal notation:

$\begin{array}{lll}T=\left\{\begin{array}{l}D_{1} \quad \text { Dominant } \\ \text { Technology Component }\end{array}\right. & \mid D_{1}=\{\text { empty }\} \\ & D_{2} \text { Value Proposition } & \mid D_{2}=\{\text { empty }\} \\ & D_{3} \text { Delivery Channel } & \mid D_{3}=\{\text { empty }\} \\ & D_{4} \text { Customers } & \mid D_{4}=\{\text { empty }\} \\ & D_{5} \text { Revenue Stream } & \mid D_{5}=\{\text { empty }\}\end{array}$

Due to the purely conceptual nature of the first iteration, several ending conditions were not met, e.g., all objects (or a representative sample) are analyzed, as displayed in Table 9: Summary of the iterations and ending.

\section{$4.4 \quad 2^{\text {nd }}$ Iteration}

For our second iteration, we followed an empirical-to-conceptual approach and analyzed the data on FinTechs described in the previous section on "Dataset Description”. We started by drawing a random sample of 150 companies that were labeled as FinTechs by the Crunchbase database. This sample was split, and each of the authors was assigned to analyze 50 companies. Thus, we were able to derive suitable characteristics for the dimensions obtained by the first iteration. The results of each author were discussed and integrated into a single taxonomy.

For example, characteristics with a very similar meaning but different names were summarized as a single characteristic, e.g., matching and intermediation to $C_{2,5}$ Matching/Intermediation, or unification and consolidation to $C_{2,10}$ Unification/Consolidation. Furthermore, during this empirical iteration, we identified 
the need for an additional dimension, $D_{6}=$ Product/Service Offering, and added it to our taxonomy, which we did not include in the deductive first iteration. We added it as a new dimension in addition to the existing value proposition dimension. We did this because when looking at the FinTech companies in our sample, it becomes apparent that for many companies there is a clear distinction between what is being delivered to the customer and the use the customer is expected to gain from the service or product.

The newly added dimension and characteristics also indicated that our taxonomy has not yet reached all ending conditions and is still changing significantly. In sum, we developed the following taxonomy for the second iteration:

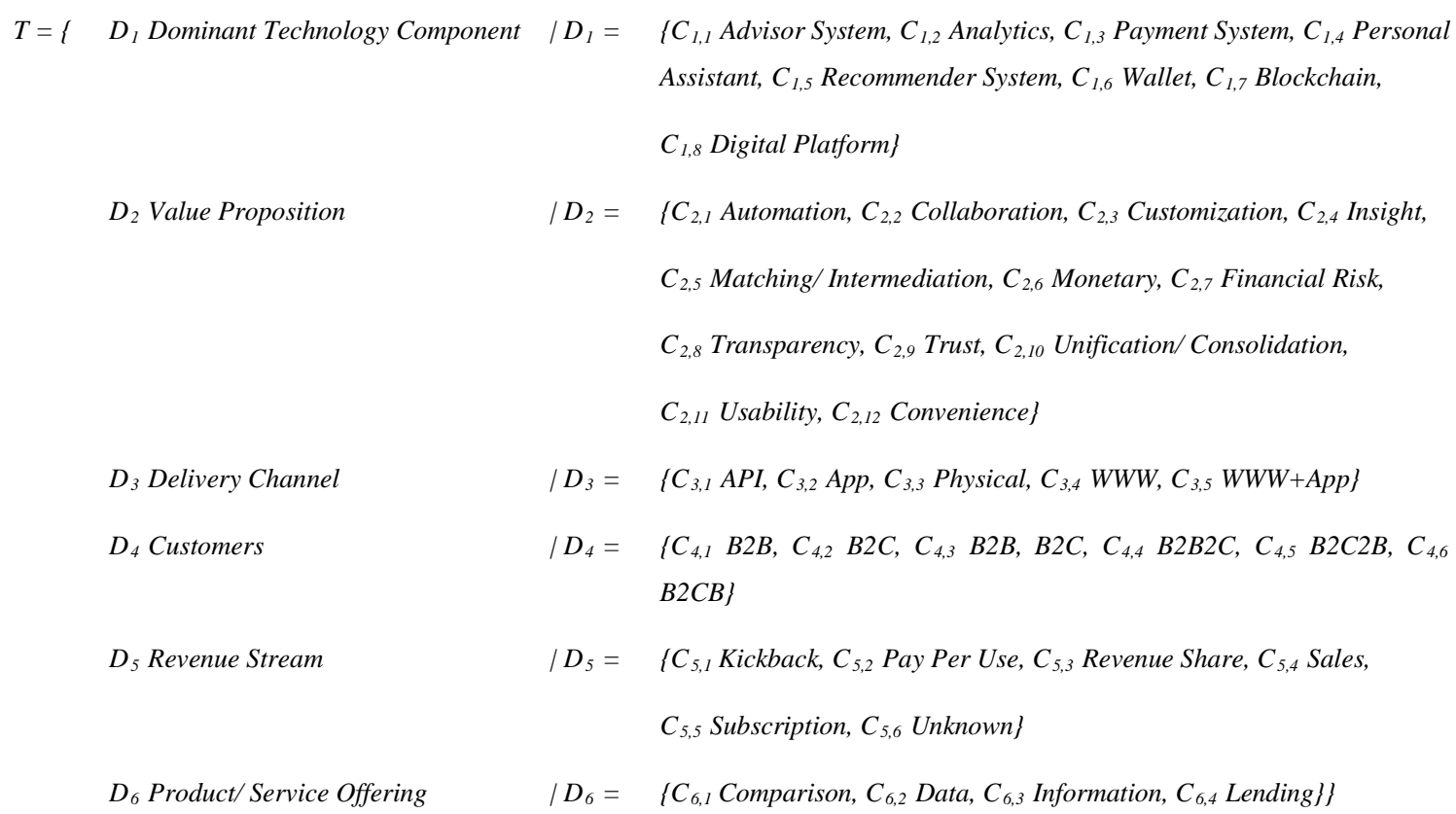

\section{$4.53^{\text {rd }}$ Iteration}

Next, we draw on a larger random sample of 600 companies, i.e., 200 per author, to test whether the dimensions and characteristics developed during iteration two are stable enough. During this iteration, we merged the characteristics $C_{1,1}$ Advisor System, $C_{1,2}$ Analytics, $C_{1,4}$ Personal Assistant and $C_{1,5}$ Recommender System with the newly added characteristic $C_{1,9}$ Decision Support System.

The reason was that $C_{1,1}$ Advisor System, $C_{1,4}$ Personal Assistant and $C_{1,5}$ Recommender System are very similar function-wise and they all encompass $C_{1,2}$ Analytics to some extent, which we subsumed to $C_{1,9}$ Decision Support System. In addition, we merged the characteristics $C_{1,3}$ Payment System and $C_{1,6}$ Wallet to the newly added overarching characteristic $C_{1,6}$ Transaction Processing System. Further 
changes within the Dimension $D_{1}$ Dominant Technology Component were the addition of the characteristics $C_{1,10}$ Marketplace and $C_{1,11}$ Database. Within $D_{4}$ Customers we condensed our taxonomy down to three characteristics, $C_{4,1} B 2 B, C_{4,2} B 2 C, C_{4,3} B 2 B$, $B 2 C$, which makes the taxonomy more concise.

The most significant changes were in the dimension $D_{6}$ Product/Service Offering. The first three characteristics, $C_{6,1}$ Comparison, $C_{6,2}$ Data and $C_{6,3}$ Information were merged to $C_{6,3}$ Information Aggregation. In addition, we identified ten new characteristics, namely $C_{6,6}$ Brokerage, $C_{6,7}$ Currency Exchange, $C_{6,8}$ Current Account, $C_{6,9}$ Device, $C_{6,10}$ Financial Education, $C_{6,11}$ Financing, $C_{6,12}$ Investments, $C_{6,13}$ Payment Service, $C_{6,14}$ Personal Assistant and $C_{6,15}$ Credit. Similar to the $2^{\text {nd }}$ iteration, our taxonomy still requires significant changes, indicating that the ending conditions have not been met. The taxonomy at the end of iteration three is notated as follows:

\begin{tabular}{|c|c|c|c|}
\hline$T=\{$ & $D_{1}$ Dominant Technology Component & $\mid D_{1}=$ & $\begin{array}{l}\left\{C_{1,7} \text { Blockchain, } C_{1,8} \text { Digital Platform, } C_{1,9} \text { Decision Support System, }\right. \\
\left.C_{1,10} \text { Marketplace, } C_{1,11} \text { Database, } C_{1,12} \text { Transaction Processing System }\right\}\end{array}$ \\
\hline & $D_{2}$ Value Proposition & $D_{2}=$ & $\begin{array}{l}\left\{C_{2,1} \text { Automation, } C_{2,2} \text { Collaboration, } C_{2,3} \text { Customization, } C_{2,4} \text { Insight, }\right. \\
C_{2,5} \text { Matching/Intermediation, } C_{2,6} \text { Monetary, } C_{2,7} \text { Financial Risk, } \\
C_{2,8} \text { Transparency, } C_{2,10} \text { Unification/ Consolidation, } C_{2,13} \text { Security, } \\
\left.C_{2,14} \text { Usability/Convenience }\right\}\end{array}$ \\
\hline & $D_{3}$ Delivery Channel & $D_{3}=$ & $\begin{array}{l}\left\{C_{3,1} \text { API, } C_{3,2} \text { App, } C_{3,3} \text { Physical, } C_{3,4} W W W, C_{3,5} W W W+A p p,\right. \\
\left.C_{3,6} \text { Instant Message }\right\}\end{array}$ \\
\hline & $D_{4}$ Customers & $D_{4}=$ & $\left\{C_{4,1} B 2 B, C_{4,2} B 2 C, C_{4,3} B 2 B, B 2 C\right\}$ \\
\hline & $D_{5}$ Revenue Stream & $D_{5}=$ & $\begin{array}{l}\left\{C_{5,1} \text { Kickback, } C_{5,2} \text { Pay Per Use, } C_{5,3} \text { Revenue Share, } C_{5,4} \text { Sales, }\right. \\
\left.C_{5,5} \text { Subscription, } C_{5,6} \text { Unknown }\right\}\end{array}$ \\
\hline & $D_{6}$ Product/Service Offering & $D_{6}=$ & $\begin{array}{l}\left\{C_{6,4} \text { Lending, } C_{6,5} \text { Information Aggregation, } C_{6,6} \text { Brokerage, }\right. \\
C_{6,7} \text { Currency Exchange, } C_{6,8} \text { Current Account, } C_{6,9} \text { Device, } \\
C_{6,10} \text { Financial Education, } C_{6,11} \text { Financing, } C_{6,12} \text { Investments, } \\
\left.C_{6,13} \text { Payment Service, } C_{6,14} \text { Personal Assistant, } C_{6,15} \text { Credit }\right\}\end{array}$ \\
\hline
\end{tabular}

\section{$4.64^{\text {th }}$ Iteration}

Last, we analyzed the remaining 1400 companies with a FinTech label. Within the dimension $D_{6}$ Product/ Service Offering we merged the characteristics $C_{6,4}$ Lending and $C_{6,15}$ Credit to $C_{6,16}$ Credit/Lending because they were identical in their meaning. Furthermore, we added two characteristics to this dimension, namely, $C_{6,17}$ Fraud 
Prevention and $C_{6,18}$ User Identification. This led us to our final taxonomy. However, the last iteration did not meet two objective ending conditions from Nickerson et al. (2013), i.e., "no dimensions or characteristics were merged or split," and "no new dimensions or characteristics were added.” Nevertheless, we stopped the development process because, after this iteration, we analyzed the largest and remaining proportion of the FinTech sample, yet our taxonomy experienced only marginal changes. The final taxonomy is visualized in Table 10 "FinTech Business Model Taxonomy" with the following formal notation:

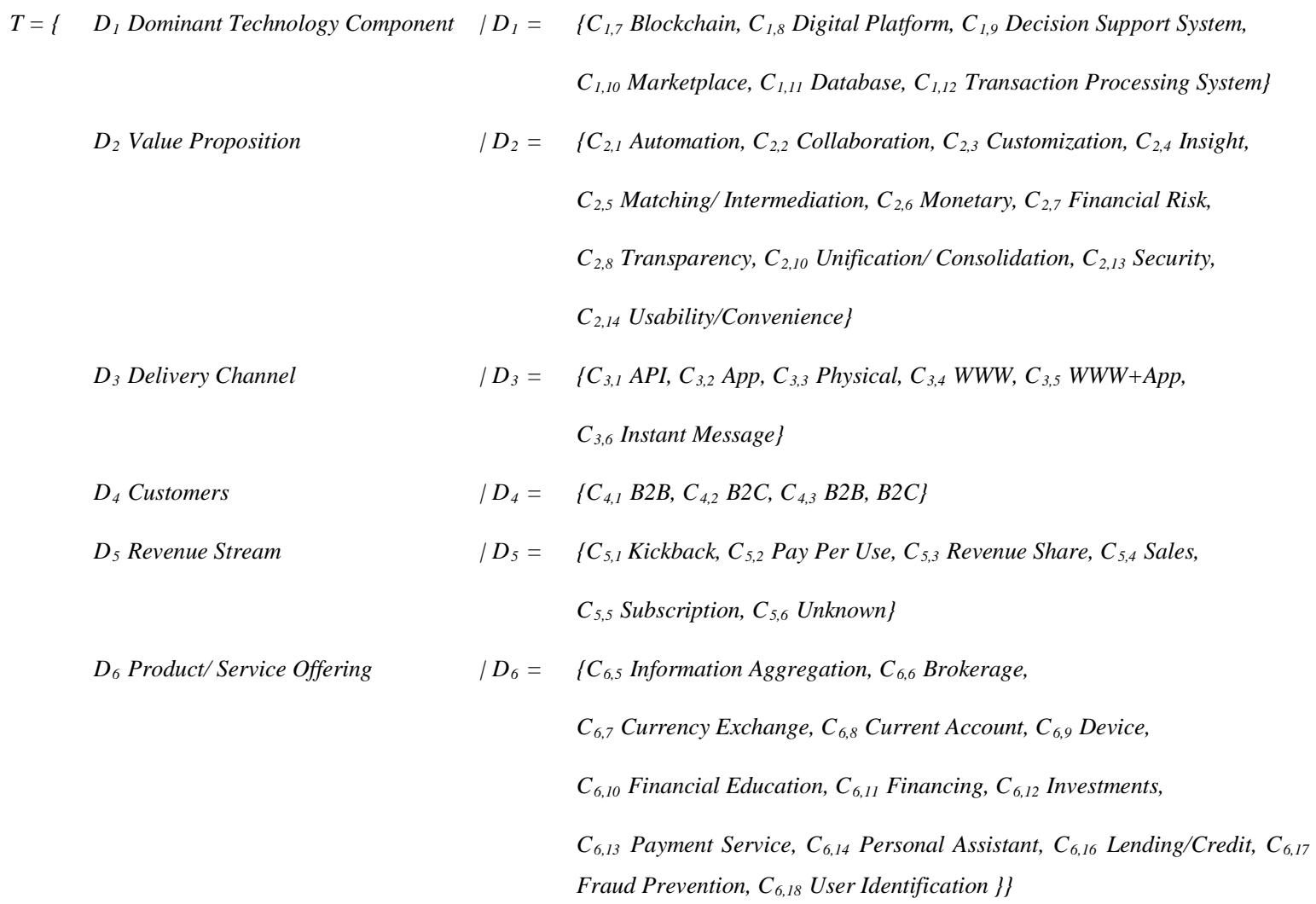

Finally, and in order to demonstrate the necessity of each iteration, Table 9 provides a summary of the four iterations and to which extent each of them contributes to fulfilling the required ending conditions. As shown, the first iteration (conceptual-toempirical) only satisfied three ending conditions, while the subsequent three iterations (empirical-to-conceptual) contributed to the satisfaction of the remaining ending conditions. As all ending conditions are satisfied for our company sample after the four conducted iterations, we consider the developed taxonomy finalized at this point. However, as the FinTech field keeps evolving, which may lead to a future violation of 
an ending condition, the developed taxonomy may be extended to reflect such changes by conducting additional development iterations.

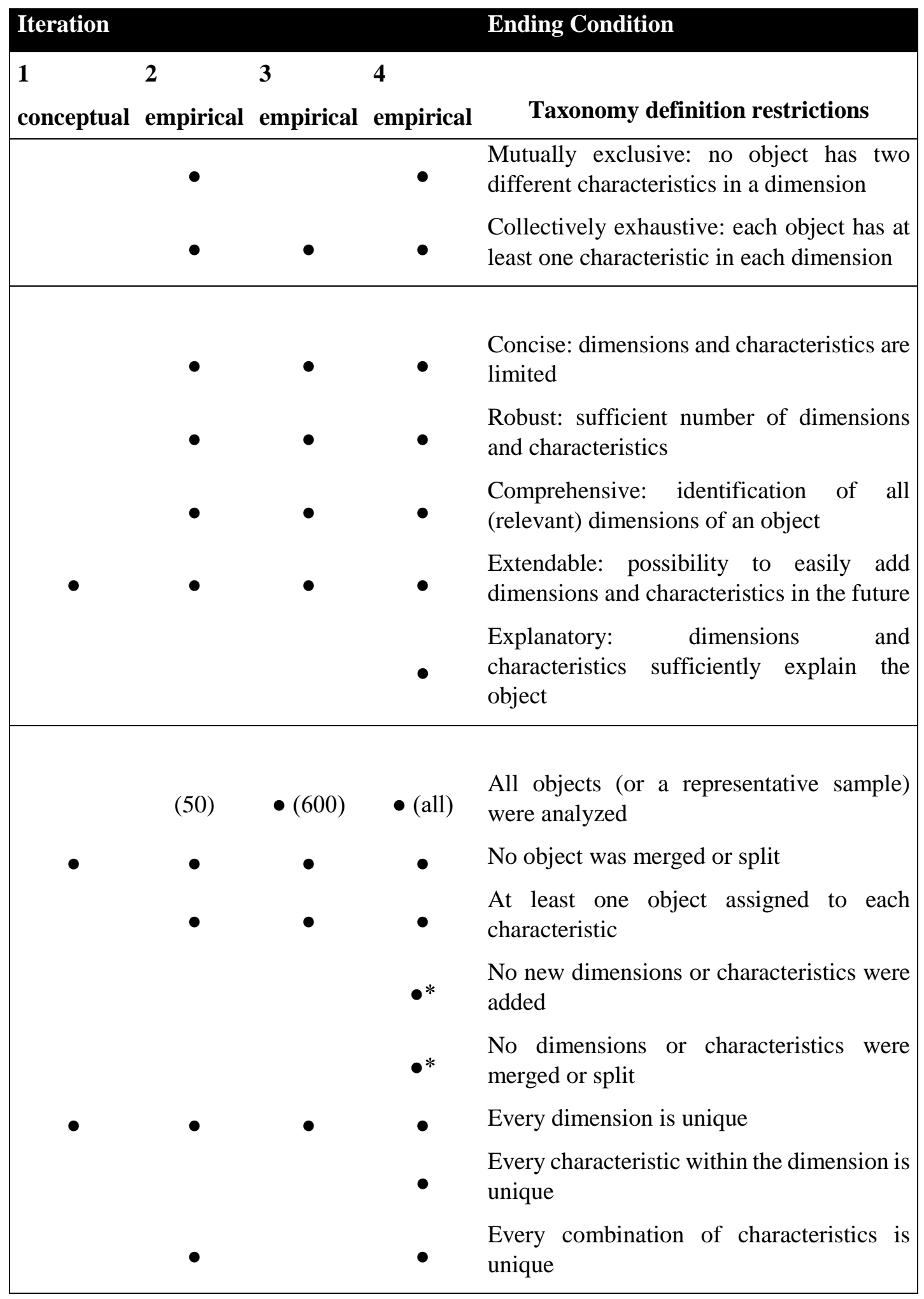

Table 9: Summary of the iterations and ending conditions. * In these cases there is a minor change, which we consider insignificant due to the size of our sample. 


\section{$5 \quad$ FinTech Business Model Taxonomy}

\begin{tabular}{|c|c|c|c|c|c|}
\hline $\begin{array}{l}\mathrm{D}_{1} \text { Dominant } \\
\text { Technology } \\
\text { Component }\end{array}$ & $\mathrm{D}_{2}$ Value Proposition & $\begin{array}{l}\mathrm{D}_{3} \text { Delivery } \\
\text { Channel }\end{array}$ & $\mathrm{D}_{4}$ Customers & $\begin{array}{l}\mathrm{D}_{5} \text { Revenue } \\
\text { Stream }\end{array}$ & $\begin{array}{l}\mathrm{D}_{6} \text { Product/ } \\
\text { Service Offering }\end{array}$ \\
\hline \multicolumn{6}{|l|}{ Characteristics $\mathrm{C}_{\mathrm{ij}}$} \\
\hline $\mathrm{C}_{1,7}$ Blockchain & $\mathrm{C}_{2,1}$ Automation & $\mathrm{C}_{3,1} \mathrm{API}$ & $\mathrm{C}_{4,1} \mathrm{~B} 2 \mathrm{~B}$ & $\mathrm{C}_{5,1}$ Kickback & $\begin{array}{l}\mathrm{C}_{6,5} \text { Inform. } \\
\text { Aggregation }\end{array}$ \\
\hline $\begin{array}{l}\mathrm{C}_{1,8} \text { Digital } \\
\text { Platform }\end{array}$ & $\mathrm{C}_{2,2}$ Collaboration & $\mathrm{C}_{3,2} \mathrm{App}$ & $\mathrm{C}_{4,2} \mathrm{~B} 2 \mathrm{C}$ & $\mathrm{C}_{5,2}$ Pay Per Use & $\mathrm{C}_{6,6}$ Brokerage \\
\hline $\begin{array}{l}\mathrm{C}_{1,9} \text { Decision } \\
\text { Support System }\end{array}$ & $\mathrm{C}_{2,3}$ Customization & $\mathrm{C}_{3,3}$ Physical & $\mathrm{C}_{4,3} \mathrm{~B} 2 \mathrm{~B}, \mathrm{~B} 2 \mathrm{C}$ & $\begin{array}{l}\mathrm{C}_{5,3} \text { Revenue } \\
\text { Share }\end{array}$ & $\begin{array}{l}\mathrm{C}_{6,7} \text { Currency } \\
\text { Exchange }\end{array}$ \\
\hline $\mathrm{C}_{1,10}$ Marketplace & $\mathrm{C}_{2,4}$ Insight & $\mathrm{C}_{3,4} \mathrm{WWW}$ & & C5,4 Sales & $\begin{array}{l}\mathrm{C}_{6,8} \text { Current } \\
\text { Account }\end{array}$ \\
\hline $\mathrm{C}_{1,11}$ Database & $\begin{array}{l}\mathrm{C}_{2,5} \text { Matching/ } \\
\text { Intermediation }\end{array}$ & $\begin{array}{l}\mathrm{C}_{3,5} \mathrm{WWW}+ \\
\text { App }\end{array}$ & & $\mathrm{C}_{5,5}$ Subscription & $\mathrm{C}_{6,9}$ Device \\
\hline \multirow[t]{8}{*}{$\begin{array}{l}\mathrm{C}_{1,12} \text { Transaction } \\
\text { Processing System }\end{array}$} & $\mathrm{C}_{2,6}$ Monetary & $\begin{array}{l}\mathrm{C}_{3,6} \text { Instant } \\
\text { Message }\end{array}$ & & $\mathrm{C}_{5,6}$ Unknown & $\begin{array}{l}\mathrm{C}_{6,10} \text { Financial } \\
\text { Education }\end{array}$ \\
\hline & $\mathrm{C}_{2,7}$ Financial Risk & & & $\mathrm{C}_{5,7}$ Free & $\mathrm{C}_{6,11}$ Financing \\
\hline & $\mathrm{C}_{2,8}$ Transparency & & & $\mathrm{C}_{5,8}$ Hybrid & $\mathrm{C}_{6,12}$ Investments \\
\hline & $\begin{array}{l}\mathrm{C}_{2,10} \text { Unification/ } \\
\text { Consolidation }\end{array}$ & & & & $\begin{array}{l}\mathrm{C}_{6,13} \text { Payment } \\
\text { Service }\end{array}$ \\
\hline & $\mathrm{C}_{2,13}$ Security & & & & $\begin{array}{l}\mathrm{C}_{6,14} \text { Personal } \\
\text { Assistant }\end{array}$ \\
\hline & $\begin{array}{l}\mathrm{C}_{2,14} \text { Convenience/ } \\
\text { Usability }\end{array}$ & & & & $\begin{array}{l}\mathrm{C}_{6,16} \text { Lending/ } \\
\text { Credit }\end{array}$ \\
\hline & & & & & $\begin{array}{l}\mathrm{C}_{6,17} \text { Fraud } \\
\text { Prevention }\end{array}$ \\
\hline & & & & & $\begin{array}{l}\mathrm{C}_{6,18} \text { User } \\
\text { Identification }\end{array}$ \\
\hline
\end{tabular}

Table 10: FinTech business model taxonomy.Overview of all dimensions $\left(\mathrm{D}_{\mathrm{i}}\right)$ and characteristics $\left(\mathrm{C}_{\mathrm{i}, j}\right)$. State after the conclusion of the development process following Nickerson et al. (2013).

After the development iterations discussed above, we provide an answer to our first research question RQ1 and arrive at the final taxonomy presented in Table 10. As shown, the taxonomy of FinTech business models contains six dimensions, each of which is composed of several characteristics. As discussed, this taxonomy satisfies the formal requirements and ending conditions required by Nickerson et al. (2013). Of course, as the developed taxonomy represents the state of the FinTech industry to-date, future additional development iterations may uncover additional relevant dimensions and/or characteristics.

Because a useful taxonomy is explanatory, not just descriptive, and to make interpreting the taxonomy easier, we elaborate on our definitions of critical characteristics that we do not consider self-explanatory. To this end, the definitions of all dimensions are shown in Table 11. As shown, each dimension refers to extant 
business model literature. Likewise, Table 13 (appendix) details the descriptions of each characteristic contained in the product or service dimension, in the dominant technology dimension, and in the value proposition dimension. We consider the characteristics of the other dimensions to be self-explanatory.

\section{Dimension}

\section{Definition}

$\mathrm{D}_{1}$ Dominant Technology Component

Dominant IT artifact that is the driver for the ITbased business model (Alt and Zimmermann 2001; Power 2004).

$\mathrm{D}_{2}$ Value Proposition

Describes the value the company creates for its ecosystem (customers, partners etc.) (Osterwalder et al. 2005).

$\mathrm{D}_{3}$ Delivery Channel

Describes how the products and services are distributed to the customers (Osterwalder et al. 2005).

$\mathrm{D}_{4}$ Customers

Describes to whom the company intends to offer its products and services (Osterwalder et al. 2005).

$\mathrm{D}_{5}$ Revenue Stream

Describes how the company generates revenue from its products or services (Alt and Zimmermann 2001; Osterwalder et al. 2005).

$\mathrm{D}_{6}$ Product/Service Offering

Describes what the company offers to its Customers (Osterwalder et al. 2005).

Table 11: Definitions of taxonomy dimensions.

\section{Archetypes of FinTech Business Models}

In order to address our second research question RQ2, we build upon our developed taxonomy of FinTech business models in order to identify typical patterns (archetypes) of business model elements from a large collection of FinTech companies, which we also extracted from the Crunchbase database. The database includes a set of business sector and technology tags for each firm.

We use these tags for a cluster-based validation of the previously identified dimensions and their characteristics. The developed taxonomy should be able to identify a representative firm archetype for each cluster, determined on the basis of the Crunchbase tags. This is also done to ensure that the most important companyarchetypes are represented in the presentation of our results. The clustering is based on the entire company sample and is consequently unbiased by our prior taxonomy development, which did not use these tags in order to preserve them for this 
demonstration, which can also serve as a check as to whether the developed taxonomy can be applied to the raw data.

In particular, we use the multiscale bootstrap resampling approach implemented in the PVClust R-package (Shimodaira 2004; Suzuki and Shimodaira 2006). In contrast to traditional approaches, this yields nearly unbiased $p$-values for each cluster (Shimodaira 2004), allowing us to assess which clusters are significantly different from their peers. This provides us with additional information when assessing whether clusters are of interest to our analysis. Figure 4 shows the resulting clusterdendrogram. As shown, the clustering results in several sensible categories, such as a “Blockchain” (7) or “Cyber Security” (32) cluster. Still, to develop these clusters into dimensions and their characteristics, further processing is needed, as not every cluster is likely to yield informative distinctions according to our initial FinTech definition (see Introduction).

Accordingly, the resulting tag clusters are examined in a two-stage analysis. First, we identify cluster-nodes in the cluster-dendrogram, which seem like promising candidates for company archetypes. Second, the companies in each cluster are reexamined manually, and the cluster is thus checked for coherence regarding the business model of the firms contained therein to assess the usefulness of each cluster beyond its quantitative presence. For the first step, a company is considered a member of a cluster if it has $>0$ tags in common with the cluster and not as many matches with another cluster.

As shown in Figure 5, the first step yields 24 candidates for relevant clusters, while 14 clusters remain after the manual coherence check and are reported in Figure 5. Cluster candidates for step 1 are determined using two criteria, the first of which serves as a sanity barrier, while the second serves as a focus check towards taxonomy development (next page): 


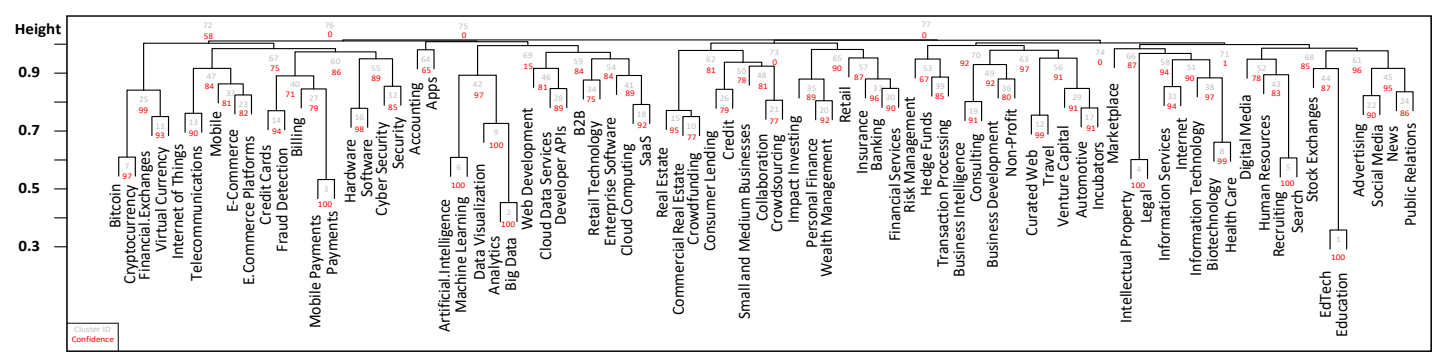

Figure 4: Cluster dendrogram of firm tags as included in the Crunchbase database. Red numbers represent approximately unbiased p-values (confidence) indicating cluster significance (note: $>.9$ is equivalent to $<.1$ for normal p-values). Grey numbers represent cluster IDs counted from the branches of the tree upwards. The difference in height between clusters can be interpreted as a distance measure between clusters.

1. The chosen category should satisfy the discussed definition of a FinTech, i.e., it should describe companies seeking to take part in areas of business traditionally covered by banks or the financial services industry or establish novel business models relevant to these sectors.

2. The chosen categories should be sufficiently distinct from one another to be able to serve as a basis for taxonomy development.

The result of step 1 is presented by cluster candidates $\mathbf{A}$ to $\mathbf{X}$, shown in Figure 5 . As described, each of these clusters is consequently examined in more detail by checking the companies contained therein for coherence and discarding a cluster if the contained companies are not FinTechs as defined in the context of this paper. Additionally, we discard a cluster if it does not contain firms with business models that are coherent regarding the tags the cluster contains or if a cluster does not contain firms. ${ }^{2}$ The clusters violating these conditions are marked with a red dot in Figure 5 below.

As noted, 14 clusters remain after these two steps. However, examining these clusters in detail, we noticed, that some clusters are also close to each other in terms of their manifestations (Figure 5). Namely, $\mathbf{B}$, and $\mathbf{E}$, $\mathbf{I}$ and $\mathbf{J}$ as well as $\mathbf{Q}, \mathbf{R}$, and $\mathbf{W}$, which then were grouped to $\mathbf{B}+\mathbf{E}, \mathbf{I}+\mathbf{J}$ and $\mathbf{Q}+\mathbf{R}+\mathbf{W}$. In doing so, we obtained ten partially grouped clusters, which we select by traveling upwards in the cluster hierarchy until a unified cluster results that passes manual introspection. Next, and in order to provide an answer to our second research question RQ2, the actual identification of FinTech

${ }^{2}$ No-firm clusters are possible because of the requirement that a firm is only assigned to a cluster if it has more tags in common with this cluster than with any other, which makes the cluster assignment very strict. As shown, this strict criterion still results in a variety of clusters. 
business model archetypes is achieved. This is done by reporting the dominant characteristic for the firms contained in these clusters for each dimension of the developed taxonomy (see Table 12). The first column of Table 12 represents the manually labeled different FinTech business model archetypes. The label is obtained by examining the most dominant characteristics of each cluster and the cluster tags. For example, the FinTech business model archetype "Payment Service” is described by cluster $\mathrm{B}+\mathrm{E}$ with a dominant technology component of a transaction processing system, the value proposition is mostly convenience/usability, which is usually delivered by an app for B2B customers. Meanwhile, the revenue stream is unknown and the product/service offering is logically a payment service.

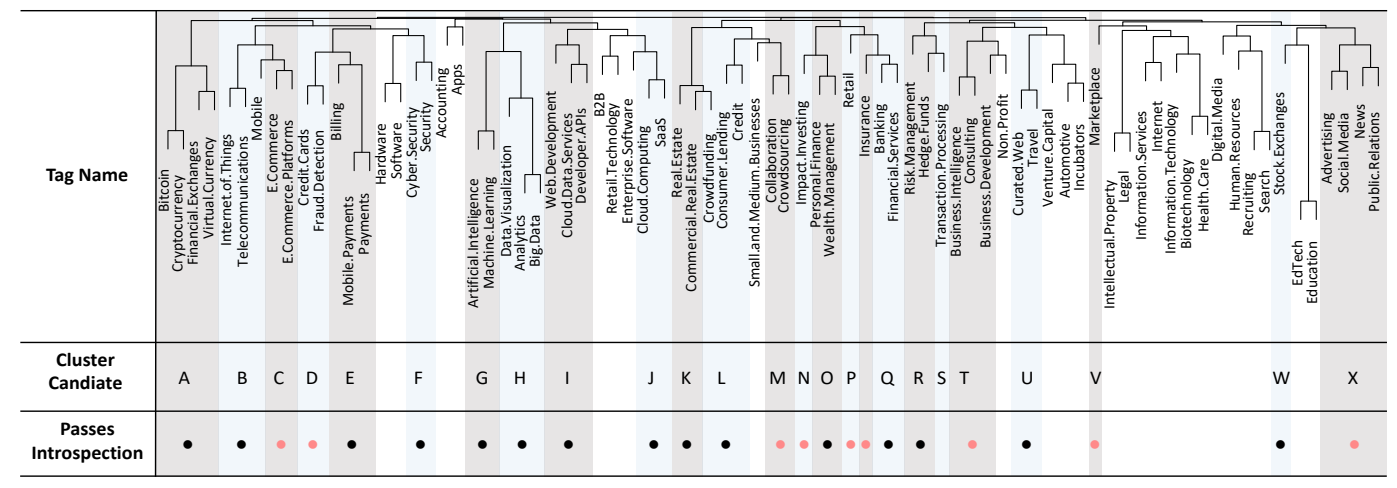

Figure 5: Coding (three coder's consensus) of clusters. To technological and entrepreneurial categories. Colored columns only serve to emphasize the clusters. Red dots indicate clusters that do not contain companies in line with the FinTech definition used here. 


\begin{tabular}{|c|c|c|c|c|c|c|c|}
\hline $\begin{array}{l}\text { Archetype } \\
\text { Label }\end{array}$ & $\begin{array}{l}\text { Cl } \\
\text { ust } \\
\text { er }\end{array}$ & $\begin{array}{l}\text { Dominant } \\
\text { Technology } \\
\text { Component }\end{array}$ & $\begin{array}{l}\text { Value } \\
\text { Proposition }\end{array}$ & $\begin{array}{l}\text { Delivery } \\
\text { Channel }\end{array}$ & $\begin{array}{l}\text { Custo } \\
\text { mers }\end{array}$ & $\begin{array}{l}\text { Revenue } \\
\text { Stream }\end{array}$ & $\begin{array}{l}\text { Product/ Service } \\
\text { Offering }\end{array}$ \\
\hline $\begin{array}{l}\text { Crypto- } \\
\text { currency }\end{array}$ & $A$ & Blockchain & $\begin{array}{l}\text { Convenience/ } \\
\text { Usability }\end{array}$ & API & B2C & Unknown & $\begin{array}{l}\text { Currency } \\
\text { Exchange }\end{array}$ \\
\hline $\begin{array}{l}\text { Payment } \\
\text { Service }\end{array}$ & $\begin{array}{l}B \\
E\end{array}$ & $\begin{array}{l}\text { Transaction } \\
\text { Processing } \\
\text { System }\end{array}$ & $\begin{array}{l}\text { Convenience/ } \\
\text { Usability }\end{array}$ & App & B2B & Unknown & $\begin{array}{l}\text { Payment } \\
\text { Service }\end{array}$ \\
\hline $\begin{array}{l}\text { Financial } \\
\text { Markets } \\
\text { Interme- } \\
\text { diary }\end{array}$ & $F$ & $\begin{array}{l}\text { Marketplace; } \\
\text { Transaction } \\
\text { Processing } \\
\text { System }\end{array}$ & $\begin{array}{l}\text { Matching/ } \\
\text { Intermediation; } \\
\text { Security }\end{array}$ & $\begin{array}{l}\text { Physical/ } \\
\text { WWW }\end{array}$ & $\mathrm{B} 2 \mathrm{~B}$ & $\begin{array}{l}\text { Sales, } \\
\text { Unknown }\end{array}$ & $\begin{array}{l}\text { Brokerage; } \\
\text { Device }\end{array}$ \\
\hline $\begin{array}{l}\text { Inform. } \\
\text { Aggre- } \\
\text { gator }\end{array}$ & $G$ & $\begin{array}{l}\text { Decision Support } \\
\text { System }\end{array}$ & $\begin{array}{l}\text { Convenience/ } \\
\text { Usability }\end{array}$ & App & $\begin{array}{l}\text { B2B, } \\
\text { B2C }\end{array}$ & Unknown & $\begin{array}{l}\text { Inform. } \\
\text { Aggregation }\end{array}$ \\
\hline $\begin{array}{l}\text { Infor- } \\
\text { mation } \\
\text { Extractor }\end{array}$ & $H$ & $\begin{array}{l}\text { Decision Support } \\
\text { System }\end{array}$ & Insight & App & $\mathrm{B} 2 \mathrm{~B}$ & Unknown & $\begin{array}{l}\text { Inform. } \\
\text { Aggregation }\end{array}$ \\
\hline $\begin{array}{l}\text { Insourcer } \\
\text { of Sub- } \\
\text { Processes }\end{array}$ & $I_{-}$ & $\begin{array}{l}\text { Decision Support } \\
\text { System }\end{array}$ & Automation & App & B2B & Unknown & $\begin{array}{l}\text { Inform. } \\
\text { Aggregation }\end{array}$ \\
\hline $\begin{array}{l}\text { Lending } \\
\text { Commu- } \\
\text { nity }\end{array}$ & K & Marketplace & $\begin{array}{l}\text { Monetary; } \\
\text { Transparency }\end{array}$ & WWW & B2C & $\begin{array}{l}\text { Revenue } \\
\text { Share; } \\
\text { Unknown }\end{array}$ & $\begin{array}{l}\text { Lending/ } \\
\text { Credit; Financing }\end{array}$ \\
\hline $\begin{array}{l}\text { Alternative } \\
\text { Trading } \\
\text { Venue }\end{array}$ & $L$ & Marketplace & $\begin{array}{l}\text { Matching/ } \\
\text { Intermediation }\end{array}$ & $\begin{array}{l}\text { WWW+ } \\
\text { App }\end{array}$ & $\begin{array}{l}\text { B2B, } \\
\text { B2C }\end{array}$ & Unknown & $\begin{array}{l}\text { Investments; } \\
\text { Lending/ } \\
\text { Credit }\end{array}$ \\
\hline $\begin{array}{l}\text { Robo } \\
\text { Advisor }\end{array}$ & $O$ & $\begin{array}{l}\text { Decision Support } \\
\text { System }\end{array}$ & Monetary & App & B2C & $\begin{array}{l}\text { Revenue } \\
\text { Share; } \\
\text { Unknown }\end{array}$ & $\begin{array}{l}\text { Personal } \\
\text { Assistant }\end{array}$ \\
\hline $\begin{array}{l}\text { Co-Creator } \\
\text { of Financial } \\
\text { Analysis }\end{array}$ & $\begin{array}{l}Q_{-} \\
R_{-} \\
W\end{array}$ & $\begin{array}{l}\text { Decision Support } \\
\text { System }\end{array}$ & $\begin{array}{l}\text { Convenience/U } \\
\text { sability }\end{array}$ & App & $\mathrm{B} 2 \mathrm{~B}$ & Unknown & $\begin{array}{l}\text { Inform. } \\
\text { Aggregation }\end{array}$ \\
\hline
\end{tabular}

Table 12. FinTech business model archetypes coded from dominant (most common occurrence) characteristic for firms within each cluster resulting from coding in Figure 5.

As shown in the table, cluster A relates to cryptocurrency based business models, which typically relate to consumer based convenience offerings. Cluster $\mathbf{B}+\mathbf{E}$ contains firms offering payment services. The prime example of firms contained in this cluster is given by PayPal, and many firms contained therein offer similar but more specialized services. The companies contained in Cluster $\mathbf{F}$ focus on offering device based security offerings that support other firms' business processes. One example of this is supplying biometric authentication for brokerage offerings.

Firms that are part of cluster $\mathbf{G}$ offer their customer information aggregation services, which focusses on the supplying of information. Going further, firms in cluster $\mathbf{H}$ focus on extracting information from such data. Cluster $\mathbf{I}+\mathbf{J}$ offers similar services but the business offerings of firms in this cluster tend to be more cloud-centric and revolve around hosting the entire service on the FinTechs servers. Cluster $\mathbf{K}$ contains lending communities, which are marketplaces for lending or financing, and often focus on 
providing micro funding or aim at providing a form of disintermediation. Similarly, cluster $\mathbf{L}$ contains firms that focus on providing alternative trading venues.

Cluster $\mathbf{O}$ relates to financial "robo" advisors, which perform actions such as user specific portfolio suggestions or credit scoring. Cluster $\mathbf{Q}+\mathbf{R}+\mathbf{W}$ offers co-creation of financial analysis, which involves tasks such as credit risk assessment but also reaches into educational offerings in this area. These archetypes present the answer to RQ2 by using the developed taxonomy to examine groups of firms regarding the commonalities in their business models, and shows how the taxonomy can be applied to specific companies.

\section{$7 \quad$ Implications}

\subsection{Implications for Research}

The first implication of this paper is its contribution toward developing a consensus on the question of what a FinTech actually is and upon what elements their business models are built. As discussed, due to the rapidly changing landscape of FinTech companies and the relative youth of the "FinTech phenomenon", the lines are not distinct. Furthermore, the lines are blurred between traditional tech firms selling their products to banks and the new phenomenon of FinTech, in which firms challenge the established banking industry by providing either what was traditionally considered a banking service or entirely new related services. To this end, the presented taxonomy of business models can be interpreted in terms of what it does not include. Considered in conjunction with the above-mentioned existing definitions of FinTech firms, this enables researchers to focus on the new phenomenon. Additionally, like all taxonomies, ours provides an overview of the studied phenomenon. Thus, the dimensions and characteristics of FinTech business models included in the taxonomy presented here help to identify different types of FinTech business models by abstraction beyond the business model of individual firms. In conjunction with the presented clustering of firm attributes, this allows for the identification of firms that are especially unlike each other, each of which represents a different facet of the FinTech landscape. In addition, the developed taxonomy and archetypes will assist researchers to find and position future contributions. Furthermore, the presented dimensions and characteristics provide a basis for further theory development and theory testing related to the FinTech phenomenon (Varshney et al. 2015). Finally, the 
iterative taxonomy development process described by Nickerson et al. (2013) allows other researchers to extend the presented taxonomy by adding further iterations if new FinTech business models are observed in the future.

\subsection{Implications for Practice}

For practitioners, business model taxonomies may at first appear very "academic" in the negative sense of the word. However, they allow for the necessary abstraction needed to identify unoccupied business models, as reflected by combinations of characteristics currently not offered by competing firms. While, naturally, not every such combination is likely to be sensible, spotting what is not being done by others is an inherently difficult problem for which academia can provide support by delivering abstractions, such as the presented taxonomy. Additionally, incumbents can use the taxonomy to gain an overview of which traditional business models are threatened by new competition and which new business models are being developed. Overall, as the industry is still developing and highly dynamic, this is a critical feature to ensure the usefulness of any taxonomy in this industry.

\subsection{Policy Implications}

The dynamic nature of the FinTech movement presents policy makers with a number of challenges, such as the identification of whether or which FinTech firms need to be subject to regulation. The presented taxonomy can provide information regarding this question. The banking sector is a highly regulated industry, in which incumbents comply with regulations regarding problems such as fraud prevention, identity theft, organized crime, and sanctions against nation states. While regulators have established processes to address these and many other concerns with incumbent firms, FinTechs have not been subject to the same level of scrutiny if they themselves have not been classified as banks or providers of financial services. This pacing problem (Marchant 2011) has yet to be fully addressed by regulators. However, the nature of FinTech business models implies that these firms face many of the same risks as traditional banks. For example, they handle similarly sensitive customer information and may be targeted by illegal activity, such as fraud. Thus, it is imperative for regulators to gain an overview of what business models are being created in this new sector of the financial industry to identify FinTechs that may play a crucial role in the financial industry, which may become relevant when considering market stability. While 
certainly not every FinTech needs to face the same scrutiny as traditional banks, parts of this new industry may create a need for new forms of regulation or an extension of the applicability of existing rules. Therefore, a taxonomy of business models is needed to enable judgment, on a case by case basis, whether any regulatory consequences should apply.

\section{$8 \quad$ Limitations and Future Research}

\subsection{Limitations}

The presented taxonomy should be used while keeping in mind several assumptions and decisions made during its development. First, regarding the development of dimensions, the selection of dimensions based on the business model literature is inherently selective. For other researchers, other dimensions may be of more interest. As discussed, this may be addressed by adding new dimensions to the taxonomy and performing additional development iterations when such extensions are desired. Due to the dynamic nature of business and the FinTech movement in particular, we cannot exclude the possibility that, for a given company, multiple possible characteristics exist, which contradicts the definition of Nickerson et al. (2013) of mutually exclusive characteristics. In this research, we opted to map each company based on its dominant characteristic if firms presented insurmountable challenges in this regard. Still, we developed the characteristics of the taxonomy with this goal in mind.

Second, regarding the development of characteristics during our empirical-toconceptual development iterations, we were inherently limited to the companies contained in our sample. While this sample is quite large, not every company has an inherent need to be listed in such a database. This is especially true for non-US or nonEU firms.

\subsection{Future Research}

In this paper, we developed a taxonomy of FinTech business models. However, the aspiration to generality limits the granularity of both the dimensions and characteristics developed to fit different types of FinTechs. Thus, future research focusing on more specialized taxonomies may provide further insights. Additionally, the developed taxonomy can be used to analyze the landscape of FinTech companies more directly. For example, clustering can be performed on the characteristics assigned to each 
company, as opposed to the approach chosen here, namely to cluster the tags not used during taxonomy development as a confirmatory effort. Such clustering could help to identify which combinations of characteristics are common and show patterns across different types of business models, identifying which roles are already being filled by companies and which are not.

Additionally, the taxonomy can be used to analyze companies based on other data points available on Crunchbase, such as funding success or the likelihood of long-term success, or which types of investors favor particular types of FinTechs. As noted, the dynamic development of the FinTech field creates a need for future investigation. New companies may follow entirely different business models than the ones included in our dataset. Thus, future research may focus on exploring whether our taxonomy still holds. 


\section{Appendix A: Description of Characteristics}

\section{Definitions of Characteristics in selected Dimensions}

\section{Product or Service}

Brokerage The service acts as an intermediary between market participants and markets (Reuters 2016).

Credit/Lending The product enables the customer to enter credit contracts as either lender or borrower (Oxford-Dictionaries 2016).

Currency "An exchange, or market, is a physical location or an electronic system in

Exchange which securities are traded in an orderly, regulated way [...]” (Reuters 2016).

Current "An account with a bank or building society from which money may be

Account withdrawn without notice, typically an active account catering for frequent deposits and withdrawals by cheque." (Oxford-Dictionaries 2016).

Device "A thing made or adapted for a particular purpose, especially a piece of mechanical or electronic equipment.” (Oxford-Dictionaries 2016).

Financial Improves the understanding of financial concepts or products (OECD Education Directorate for Financial and Enterprise Affairs 2005).

Fraud The product intends to either prevent fraud from happening (fraud Prevention prevention) or detect fraud after the fact (fraud detection) (Bolton and Hand or Detection 2002).

Information The product collects information from multiple sources and provides the Aggregation user with an aggregated information basis.

Investments Investing money for profit beyond lending money, e.g., real estate investments (Oxford-Dictionaries 2016).

Payment A service that enables users to send and receive payments.

Service

Personal

Assistant

The system provides the user with recommendations on which the user may choose to act, e.g., the recommendation of a portfolio structure (Resnick and Varian 1997), e.g., routing information.

User $\quad$ The system authenticates user identity (Todorov 2007).

Identification

\section{Dominant Technology Component}

Blockchain $\quad$ "[...] is a distributed database in digital form maintaining a continuouslygrowing list of records which are grouped into blocks and protected against malicious alteration through being encrypted and grouped into blocks" (Cohen et al. 2016).

DSS “[...] are interactive computer-based systems, which help decision- makers interactive computer-based systems to solve unstructured problems" (Morton 1971).

Marketplace "[...] facilitating the exchange of information, goods, services, and payments. In the process, they create economic value for buyers, sellers, market intermediaries, and for society at large” (Bakos 1998). 
Table 16 cont.

\section{Definitions of Characteristics in selected Dimensions}

Platform "[...] a building block, providing an essential function to a technological system - which acts as a foundation upon which other firms can develop complementary products, technologies or services” (Gawer 2011).

Database $\quad$ "[...] is basically a computerized record-keeping system; in other words, it System is a computerized system whose overall purpose is to store information and to allow users to retrieve and update that information on demand" (Date 2004).

Transaction "[...] is a collection of transaction programs designed to do the functions Processing necessary to automate a given business activity” (Bernstein and Newcomer System 2009).

\section{Value Proposition}

Automation A machine agent (computerized system) that executes a function previously carried out by a human (Parasuraman and Riley 1997; Parasuraman et al. 2000).

Collaboration "The action of working with someone to produce something" (OxfordDictionaries 2016).

Convenience/ "The ease of use and the degree to which it is easy for the user to understand Usability the system in order to use it for its intended purpose” (ISO 2010).

Customization The ability to either customize a product according to the user's wishes or letting the customer accomplish such customization (Hart 1995; Pine et al. 1993).

Financial Risk The product is intended to make financial risks, i.e., uncertainty about future returns due to market developments, more manageable (Reuters 2016).

Insight Provides the user with the means to advance his or her knowledge (Chang et al. 2009).

Matching/ The products make it easier for buyers and sellers to align their transaction Intermediation intentions by providing them with the means of discovering each other (Spulber 1996).

Monetary The product promises financial gains.

Security We follow the CIA-Triangle definition of security, i.e., the product intends to improve users' perceived or actual security by addressing systems' [C]onfidentiality, [I]ntegrity or [A]vailability (Avizienis et al. 2004).

Transparency Increasing market fairness by enabling market participants to act on more timely or comprehensive information (Madhavan 2000).

Unification/ "The action or process of combining a number of things into a single more Consolidation effective or coherent whole.” (Oxford-Dictionaries 2016).

Table 13: Definitions of characteristics. For each characteristic, a reference to a description or our own understanding of what is contained therein is provided. 


\section{Contributions}

The third and last section of this thesis addresses the summary, implications, limitations and future research of the four presented papers. It is divided into the two research areas of DSB execution and digital business models. For the first research area, DSB execution, this section C. recites the papers by Weinrich (2017, paper I), Gregory et al. (2017, paper II) and Weinrich et al. (2016b, paper III). It contains a general literature review and two specific cases within the financial services industry. In sum, it recites how different companies approach a DBS. In particular, the two cases highlight ways of how two incumbent financial service providers execute their DBS by showing the challenging introduction of agile methods and the IT transformation towards a digital platform for value co-creation. The second research area, digital business models, recites the study by Eickhoff et al. (2017, paper IV). It highlights what characteristics and dimensions of digital business model and archetypes are evident in the financial services industry, i.e., the manifestation of the FinTech movement. Overall, section $\mathrm{C}$ draws from the individual contributions in a repetitive manner and serves to establish the direct relations between the individual contributions towards an integrative and holistic picture of the dissertation. 


\section{Summary and Synthesis of Findings}

This section summarizes the findings regarding the research questions outlined in section 2. It is done by restating each research question and providing a summary of results.

\subsection{Research Area I: Digital Business Strategy Execution}

This research area highlights the impact of digitalization on companies and how they execute an adequate DBS. Logically, it addresses the first research question by elaborating on the state of knowledge:

RQ I.1. What is the state of knowledge on digital business strategy execution?

To answer the research question, Weinrich (2017, paper I) conducted a literature review, that sheds light on DBS and organizational design, whereby organizational design is considered the interrelating components of strategy, structure, processes, rewards and people (Bharadwaj et al. 2013; Galbraith 1977). Considering strategy, it is evident that digital technologies must be an integral part of DBS. However, the majority of identified articles specialize on certain digital technologies under DBS and do not treat them in a holistic manner as frequently emphasized (Ross et al. 2015). Additionally, there is a strong focus on harnessing cloud computing, data analytics and social media under DBS, whereas mobile technologies are underrepresented but not less important (Cisco 2017). In terms of structures, this piece of research notes that under DBS organizational functions become increasingly decentralized. It is also evident that the reporting structures and decision-making power shifts since DBS is an organization-wide endeavor and requires orchestration within and across organizations. However, how organizations achieve this is quite heterogeneous (Matt et al. 2015). In regard to the component processes, an increasing interfacing with the ecosystem, which includes customers, partners, suppliers and possibly competitors, is key. Organizations need to be capable of leveraging their ecosystem because it is a critical source of value creation by fostering innovation, for example (Keen and Williams 2013). Regarding the component rewards, the literature review found surprisingly little on harmonizing individual behavior with the overall goal of an organization. While research mentions the importance of this aspect, little information is given. Finally, the component people shows that to enable a DBS, digitally skilled employees and leaders are required who understand digital technologies, their strategic 
implications and know how to create business value from it. In sum, Weinrich (2017, paper I) shows that to execute a DBS, organization design requires a large shift. However, organizational design components for DBS should not be treated as mutually exclusive but as interrelating components that must be closely aligned to complement each other to be successful.

The studies of Gregory et al. (2017, paper II) and Weinrich et al. (2016b, paper III) provide the answer to the second research question of the first research area:

RQ I.2. How do financial service providers execute a digital business strategy?

First, the study of Gregory et al. (2017, paper II) closes an important gap in the understanding of the socio-technical platform design choices that help resolve the fundamental tension between IT efficiency and IT flexibility to enable multi-firm value co-creation. The findings show that firms confronting the rise of DBS must transform their IT architecture into a digital platform that achieves a synthesis between IT efficiency and IT flexibility. This paper shows a case of a financial data brokerage and services provider that transformed its existing IT architecture into a digital platform. Drawing on the design science paradigm, a set of design principles that highlight a both/and approach to combining IT efficiency and IT flexibility to enable multi-firm value co-creation is developed. Specifically, the design principles are reliability-responsiveness (platform infrastructure layer), control-extensibility (platform data layer), and standardization-variety (platform services layer). Ultimately, the study's contribution is an information design theory presented as design product along with its four key components of (1) meta-requirements, (2) metadesign, (3) kernel theories and (4) testable design product hypothesis. The (1) Metarequirements are given by providing a prescriptive foundation and abstract blueprint for building a digital platform that resolves the tension between IT efficiency and IT flexibility as a basis for multi-firm value co-creation. The (2) Meta-design is described by the aforementioned design principles. i) Reliability-responsiveness: The infrastructure layer of a digital platform should have the capacity to fulfill fluctuating and unpredictable demands for processing large volumes of data in real-time while simultaneously ensuring maximum service availability, stability, and continuity for customers. ii) Control-extensibility: The data layer of a digital platform should have the capacity to integrate, structure, and share heterogeneous data among diverse ecosystem stakeholders (customers, partners, etc.) while simultaneously regulating 
access, use, and modification of data on the platform. iii) Standardization-variety: The services layer of a digital platform should have the capacity to allow a heterogeneous set of internal and external developers to easily draw on existing business functionalities and develop individualized solutions while simultaneously ensuring interoperability of all solution components and boundary resources. The (3) Kernel theory is the integrated knowledge about IT architecture (e.g., Schmidt and Buxmann 2011) and IT transformation (e.g., Gregory et al. 2015) on the one hand, and DBS (e.g., Bharadwaj et al. 2013) and multi-firm IT value co-creation (e.g., Grover and Kohli 2012) on the other hand. Finally, (4) the testable design product propositions are: first, a platform design that exhibits the characteristics of reliability and responsiveness at the infrastructure layer increases the likelihood of resolving the fundamental tension between IT efficiency and IT flexibility; second, a platform design that exhibits the characteristics of control and extensibility at the data layer increases the likelihood of resolving the fundamental tension between IT efficiency and IT flexibility; and third, a platform design that exhibits the characteristics of standardization and variety at the application and services layer increase the likelihood of resolving the fundamental tension between IT efficiency and IT flexibility.

Second, the study of Weinrich et al. (2016b, paper III) shows case in which an incumbent financial service provider engaged in agile methods for DBS execution. Its former stable environment has changed dramatically in recent years. The financial crisis and stricter regulation, changing customer behavior, new competitors (FinTechs) and digitalization are major reasons for the turbulent and dynamic environment confronting the company. Therefore, one way to cope with such changing requirements is the use of agile methods to secure the competitiveness as an incumbent financial service provider. However, incumbent companies usually have historically grown structures that rather fit to classic development methods such as the incumbent financial service provider of this case. Thus, the introduction of agile development methods for DBS execution represents a fundamental challenge. The study by Weinrich et al. (2016b, paper III) highlights a case that shows such challenges, whereby the conceptualized challenges are integrated into the dimensions of organization itself, it's processes and employees (based on Nerur et al. 2005). Within the dimension organization, this study shows that the required resources for projects are not adequately provided and represent a challenge for both, classic and agile methods. Within the dimension employees, two major challenges were identified for 
introducing agile methods for DBS execution. First, the challenge project manager capacity and activities means that the necessary capabilities for agile methods need to be built up. At the same time, it also implies higher demands to the overall company, since usually both classic and agile methods are used in parallel because not all project are suitable for agile/classic methods. Second, agile methods knowledge and understanding highlights the challenge of a common and company-wide understanding of agile methods, which needs to be established. This includes, e.g., the meaning of agile methods, which projects are suitable for agile methods, and which requirements need to be satisfied for a seamless introduction of agile methods. Finally, within the dimension of processes, this study shows that existing project management system and processes can be challenging for the introduction of agile methods. This especially accounts for incumbent companies, which usually have established project management systems and processes that are set up for classic methods, as opposed to innovative startups, e.g., FinTechs, which do not show these historically grown systems and processes. Consequently, agile methods need to be anchored formally as well.

In sum, the two studies show ways of DBS execution for financial service providers. Gregory et al. (2017, paper II) show how a financial services company executed a DBS by developing a digital platform. Weinrich et al. (2016b, paper III) shows how a financial service provider engaged in agile methods for DBS execution. Both studies also highlight that incumbent financial service providers are limited by their pre-digital origin such as a rather inflexible existing IT infrastructure or the strong focus on classical methods.

\subsection{Research Area II: Digital Business Models}

The second research area highlights the impact of digital technology on business models in the financial services industry. It shows, that technology exceeds mere process automation and increased efficiency towards an enabling role of innovative digital business models (Fichman et al. 2014).

In this cumulative dissertation, the study of Eickhoff et al. (2017, paper IV) developed a FinTech a business model taxonomy The development process occur in an iterative manner both, empirically and conceptually, based on Nickerson et al. (2013). It resulted in six dimensions, i.e., value proposition, delivery channel, customers, revenue stream, product/service offering and dominant technology component. Each 
dimension, in turn, contains different characteristics. For example, the dimension dominant technology component has the dimensions blockchain, digital platform, decision support system, marketplace, database and transaction processing system. (refer to Eickhoff et al. (2017, paper IV) in this dissertation for the entire taxonomy). In sum, the developed taxonomy provides the answer to the first research question of the second research area of this thesis:

RQ II.1: What dimensions and characteristics exist for digital business models in the financial services industry?

Moreover, the archetypes of FinTech business models are obtained by clustering the initial company sample based on a set of business sector and technology tags for each firm given by the database. While not every cluster is likely to yield informative distinctions according the initial FinTech definition further processing was needed. (see Eickhoff et al. (2017, paper IV) for details). It resulted in promising candidates for company archetypes, which were re-examined manually. The cluster is thus checked for coherence regarding the business model of the firms contained therein to assess the usefulness of each cluster beyond its quantitative presence. Next, the actual identification of FinTech business model archetypes is achieved. This was done by reporting the dominant characteristic for the firms contained in these clusters for each dimension of the developed taxonomy. Finally, manually labeled different FinTech business model archetypes were identified, whereby the label is obtained by examining the most dominant characteristics of each cluster and the cluster tags. For example, the identified FinTech business model archetype "Payment Service" is described (referring to the developed taxonomy) by the single clusters of dominant technology component of a transaction processing system. The value proposition is mostly convenience/usability, which is usually delivered by an app for B2B customers. The revenue stream is unknown and the product/service offering is logically a payment service. In sum, this approach shows the comprehensiveness of the developed FinTech taxonomy and validated it, i.e., it is able to explain the clusters adequately and in a meaningful manner. Thus, it successfully addresses the second research question of the second research area of this thesis:

RQ II.2: What are typical innovative digital business models in the financial services industry? 


\subsection{Synthesis of Findings}

This subsection shows briefly, that findings of both research areas are directly linked to each other. The first research area of DBS is connected to second research area digital business models due to the fact that "[...] strategy reflects what a company aims to become, while business models describe what a company really is at a given time” (DaSilva and Trkman 2014, p. 383). This view is recognized in the literature stream on business models cf. Richardson (2008), whereby Osterwalder and Pigneur (2002, p. 2) state that a business model is "[...] the conceptual and architectural implementation of a business strategy [...]”. The following figure highlights the connection between both research areas:

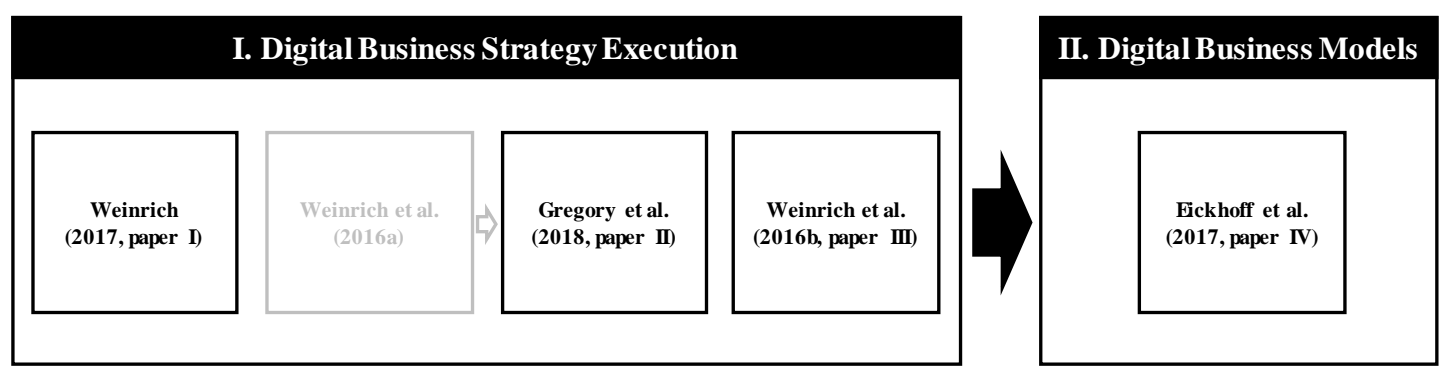

Figure 6: Connection between the research areas.

One distinction must be made. The first research area addresses DBS execution of incumbent financial service providers in the financial services industry. The second research area addresses FinTech business models in the financial services industry. However, we witness that incumbents experience limitations of their business models and therefore engage in DBS execution to achieve an adequate business model for the digital age (Bharadwaj et al. 2013; El Sawy et al. 2010). Additionally, this dissertation shows that executing such a strategy usually involves transformational efforts and adaptations, which is a complex undertaking and difficult for incumbent companies (Kotter 1995). In sum, we witness that by executing a DBS, incumbents want to realize a digital business model that innovative FinTech startups already show. For example, by transforming their own business model or by engaging in some sort of value cocreation in an ecosystem context. This fact is underpinned when looking at the business model dimensions and characteristics in the study of Eickhoff et al. (2017, paper IV) and comparing them with the key themes of DBS. For example, the FinTech taxonomy dimension digital platform along with the value proposition of collaboration is congruent with the DBS key theme of scale, in which modular platform settings, alliances and collaborations form to share and leverage digital resources that 
complement each other to create value that a company on its own would not be able to offer.

\section{Implications}

\subsection{Research Area I: Digital Business Strategy Execution}

Weinrich (2017, paper I) has research and practical implications. The research implications for literature reviews are uncovering research gaps and pinpointing possible future research questions. Thus, a review typically can give guidance for future research (Webster and Watson 2002). The research implications are presented along the framework that was used for the literature review, i.e., of strategy, structure, processes, rewards and people. For strategy, possible future research directions encompass how and which single and formerly isolated solutions in social, mobile analytics, and cloud technologies complement each other. Due to this, future research is emphasized to yield an integrative and holistic picture of digital technologies under DBS. While mobile devices are becoming smarter and mobile data traffic is increasing exponentially, their implications for DSB have still not been examined and require future research. For the component structure, one can observe heterogeneous approaches of organizations. Therefore, an analysis of which structure may lead to superior organizational performance is emphasized. This may include reporting structures and distribution of power in general, new roles such as the CDO, team settings such as cross-functional teams etc. For the component processes, integrating and analyzing different sources of large amounts of data is becoming an increasingly important differentiator and a source of value. However, research at the intersection of DBS and digital platforms, i.e., how do incumbent firms build a digital platform for multiple actors and make use of big data, is still scarce. Another research gap is evident for the component rewards. Future research may look at how to harmonize individual behavior with DBS, including metrics and measures. Finally, organizational design can influence not only organizational performance but also organizational culture (Kates and Galbraith 2010). Organizational culture is an output of the "[...] cumulative design decisions that have been made in the past and of the leadership and management behaviors that result from those decisions.“ (Kates and Galbraith 2010, p. 3). This means that leadership cannot directly influence organizational culture, only indirectly via the organizational design. The impact of DBS on organizational performance has 
been proposed and examined in some recent contributions, e.g., (Freitas Junior et al. 2016; Leischnig et al. 2016). However, little is known regarding how culture changes or appears under an organizational design for DBS. Therefore, future research should elaborate on this topic. Additionally, drawing on a different framework for DBS could yield additional insights. Finally, a change in organizational design under DBS indents to unleash new capabilities, which in turn may lead to a new business models (DaSilva and Trkman 2014). Thus, we should question, what new or typical business models result from pursing DBS with a corresponding organizational design.

The practical implications of the study Weinrich (2017, paper I) highlight the need for a suitable organizational design under DBS. In doing so, this review also shows practical audience, common organizational shifts for the components strategy, structures, processes, rewards and people. These design components are directly under the control of leaders, and therefore, organizations pursuing a DBS can draw from these insights and transfer them to their organizational context. Moreover, companies should reconsider existing portfolios of single DBS speedboat initiatives and treat them in a more holistic manner by orchestrating them. By doing so, the initiatives complement each other meaningfully and unleash their full potential.

The study of Gregory et al. (2017, paper II) likewise shows research and practical implications. A research implication of the study is the need to pay closer attention to the role of the artifact and digital platform design choices in particular. Value is increasingly co-created among multiple partnering firms within digital ecosystems (Grover and Kohli 2012; Selander et al. 2013). The study extends this understanding by shedding light on the specific platform design choices that enable such ecosystemlevel value co-creation (de Reuver et al. 2017). The implication of these findings for research on DBS is the need to extend the focus of analysis from new value systems (Pagani 2013), business models (Giessmann and Legner 2016), and innovation mechanisms (Huang et al. 2017) to architectural design choices (Hanseth and Lyytinen 2010). A further implication that follows from the study for research on IT transformation (Besson and Rowe 2012) is the need to pay close attention to the question of how and why digital platforms emerge, evolve, and ultimately transform business models and value systems. While research has started to move in this direction (Gregory et al. 2015), this study represents the first systematic attempt at describing the specific design choices and architectural considerations during the process of IT transformation that lead to the emergence and evolution of a digital 
platform, thereby closing a recently highlighted gap in the literature (de Reuver et al. 2017). The findings imply that the locus of DBS in established organizations is the interface between historically grown artifacts and structures on the one hand and newly emerging artifacts and networked structures underpinning digital ecosystems, on the other hand. More research attention must to be given to the specific nature of DBS execution. What the study suggests is that the digital platform is a useful unit of analysis to shed light on this topic.

In addition to drawing on the design theory for prescriptive (product and process) advice on how to build a digital platform that enables value co-creation, a further recommendation for practice, (especially emerging digital platform owners) is to build a long-term vision for new future value creation opportunities that initiate either one of the following two shifts: first, leveraging the digital platform to address the known needs of existing clients in very different ways (e.g., more personalized by harnessing personal data and analytics capabilities); second, fundamentally reimagining which needs, clients, and markets could be addressed in the future by drawing on the digital platform as a foundation for radical business model innovation (e.g., a long-tail strategy of democratizing access to business services in an underserved market through a platform-based solution that is highly scalable and minimizes transaction costs).

The study of Weinrich et al. (2016b, paper III) highlights research and practical implications. A research implication is given by the contribution and extension of the literature streams DBS and agile project management. Agile methods are becoming increasingly popular in the financial services industry for DBS execution. However, this study also shows that incumbents face key challenges for introducing agile methods.

This fact translates to the practical implications. Incumbent companies with similar (pre-)existing conditions, e.g., structures, may draw on the insights of this research study, gain awareness of the necessary conditions for agile methods and transfer them to their company. Useful measures for overcoming these challenges may be found in, e.g., communicating what agile methods are and what they are not, to establishing an organization wide understanding and acceptance to set up the necessary conditions. This also includes an official formalization and guidelines within the company project management system -in parallel to the classic methods. Additionally, next to the formal part, the necessary knowhow and competencies of agile methods must to be 
established within the company by, e.g., conducting trainings for key roles (such as Scrum Master, Product Owner).

\subsection{Research Area II: Digital Business Models}

In the following section, research implications, practical implications, and policy implications of the study Eickhoff et al. (2017, paper IV) are recited. A research implication of this paper is its contribution towards developing a consensus on the question of what a FinTech actually is and upon what elements their business models are built. As discussed, due to the rapidly changing landscape of FinTech companies and the relative youth of the FinTech phenomenon, the lines are not distinct. Furthermore, the lines are blurred between traditional tech firms selling their products to financial service companies and the new phenomenon of FinTech, in which firms challenge the established financial services industry by providing either what was traditionally considered a financial service or entirely new related services. To this end, the presented taxonomy of business models can be interpreted in terms of what it does not include. Considered in conjunction with the existing definitions of FinTech firms, this enables researchers to focus on the new phenomenon. Additionally, like all taxonomies, this contribution provides an overview of the studied phenomenon. Thus, the dimensions and characteristics of FinTech business models included in the taxonomy presented here help to identify different types of FinTech business models by an abstraction beyond the business model of individual firms. In conjunction with the presented clustering of firm attributes, this allows for the identification of firms that are especially unlike each other, each of which represents a different facet of the FinTech landscape. In addition, the developed taxonomy and archetypes will assist researchers to find and position future contributions. Furthermore, the presented dimensions and characteristics provide a basis for further theory development and theory testing related to the FinTech phenomenon (Varshney et al. 2015). Finally, the iterative taxonomy development process described by Nickerson et al. (2013) allows other researchers to extend the presented taxonomy by adding further iterations if new FinTech business models are observed in the future.

The study also highlights the following practical implications. For practitioners, business model taxonomies may at first appear very academic in the negative sense of the word. However, they allow for the necessary abstraction needed to identify unoccupied business models, as reflected by combinations of characteristics currently 
not offered by competing firms. While naturally, not every such combination is likely to be sensible, spotting what is not being done by others is an inherently difficult problem for which academia can provide support by delivering abstractions, such as the presented taxonomy. Additionally, incumbents can use the taxonomy to gain an overview of which traditional business models are threatened by new competition and which new business models are being developed. Overall, as the industry is still developing and highly dynamic, this is a critical feature to ensure the usefulness of any taxonomy in this industry.

Finally, policy implications are given by the dynamic nature of the FinTech movement that confront policy makers with a number of challenges. For example, this includes the identification of whether or which FinTech firms need to be subject to regulation. The presented taxonomy can provide information regarding this question. The financial services sector is a highly regulated industry, in which incumbents comply with regulations regarding problems such as fraud prevention, identity theft, organized crime, and sanctions against nation states. While regulators have established processes to address these and many other concerns with incumbent firms, FinTechs have not been subject to the same level of scrutiny if they themselves have not been classified as banks or providers of financial services. This pacing problem has yet to be fully addressed by regulators (Marchant 2011). However, the nature of FinTech business models implies that these firms face many of the same risks as traditional financial service provers. For example, they handle similarly sensitive customer information and may be targeted by illegal activity, such as fraud. Thus, it is imperative for regulators to gain an overview of what business models are being created in this new sector of the financial industry to identify FinTechs that may play a crucial role in the financial industry, which may become relevant when considering market stability. While certainly not every FinTech needs to face the same scrutiny as traditional financial services companies, parts of this new industry may create a need for new forms of regulation or an extension of the applicability of existing rules. Therefore, a taxonomy of business models is needed to enable judgment, on a case by case basis, whether any regulatory consequences should apply. 


\section{$3 \quad$ Limitations}

\subsection{Research Area I: Digital Business Strategy Execution}

The study of Weinrich (2017, paper I) has certain limitations. For example, an organizational design framework is adopted and is rather focused on a single company and excludes an in-depth examination of DBS from an ecosystem perspective -a frequently mentioned aspect of the digital economy, e.g., Pagani (2013). Therefore, as mentioned in the future research and implications section, a different framework may lead to additional insights. Moreover, a limitation may also be the search process of a literature review. For example, this literature review explicit used a keyword search for digital strategy or DBS. While the sample was created to the best of the author's knowledge and covered the most relevant studies, different approaches to the search process may include different articles for analysis.

A limitation of the study Gregory et al. (2017, paper II) is the evaluation of the digital platform/artifact description. While close attention was paid to the expository artifact instantiation, the specific instantiation elements linked to the meta-requirement of resolving the tension between IT efficiency and IT flexibility, and the evaluation concepts proof-of-concept and proof-of-value, the evaluation in terms of proof-of-use has been limited. In particular, this means the examination of the business impact and effectiveness of the specific services that run on top of the digital platform at FinIS. While specific services were identified and described in the evaluation section, no client-side evidence about the impact and utility of these platform services was collected and analyzed. However, this is in line with de Reuver et al. (2017), who observed the following: "Evaluation approaches for platforms are difficult to develop" (p. 7). In summary, the single-organization and qualitative research design of the study limited a more in-depth artifact evaluation.

A similar limitation also accounts for Weinrich et al. (2016b, paper III). The analysis is based on collected data within a single case organization and the interviews only account for a single segment of the IT project management division. The findings also primarily highlight challenges of introducing agile methods for DBS execution. 


\subsection{Research Area II: Digital Business Models}

The presented taxonomy of Eickhoff et al. (2017, paper IV) should be used while keeping in mind several assumptions and decisions made during its development. First, regarding the development of dimensions, the selection of dimensions based on the business model literature is inherently selective. For other researchers, other dimensions may be of more interest. As discussed, this may be addressed by adding new dimensions to the taxonomy and performing additional development iterations when such extensions are desired. Due to the dynamic nature of business and the FinTech movement in particular, the possibility that, for a given company, multiple possible characteristics exist, which contradicts the definition of mutually exclusive characteristics, cannot be excluded (Nickerson et al. 2013). In this research, each company was mapped based on its dominant characteristic if firms presented insurmountable challenges in this regard. Still, the characteristics of the taxonomy were developed with this goal in mind. Second, regarding the development of characteristics during the empirical-to-conceptual development iterations, the study was inherently limited to the companies contained in our sample. While this sample is quite large, not every company desires to be listed in such a database. This is especially true for non-US or non-EU firms.

\section{$4 \quad$ Future Research}

\subsection{Research Area I: Digital Business Strategy Execution}

The study of Weinrich (2017, paper I) highlights several possibilities for future research. As stated previously, an implication of a literature review is to uncover research gaps and highlight possible future research questions (Webster and Watson 2002). Therefore, please refer to the section of implications for a detailed view on future research possibilities. In sum, Weinrich (2017, paper I) emphasizes examining the impact of digital technologies not in an isolated way but looking at the holistic picture of digital technologies under DBS. Another future research direction is given by examining the intersect of DBS and digital platforms, i.e., how incumbent firms build a digital platform for DBS execution. Next, little is known about the organizational design component of rewards under DBS. Future research may look at how to harmonize individual behavior with DBS, including suitable metric and measures. Furthermore, an analysis of the link between organizational structure and 
organizational performance is suggested. Finally, little is known regarding how culture change looks under an organizational design for DBS. Therefore, future research may elaborate on this topic as well.

As discussed in Gregory et al. (2017, paper II), possible future research result from the propositions of the developed design theory. These propositions propose a close linkage between IT transformation and platform design choices on the one hand and DBS on the other hand. However, prior research on IT architecture (e.g., Schmidt and Buxmann 2011) and IT transformation (e.g., Gregory et al. 2015) on the one hand and DBS (e.g., Bharadwaj et al. 2013) and multi-firm value co-creation (e.g., Grover and Kohli 2012),on the other hand, have developed rather independently from one another. As the force of digitalization is extending to an increasing number of sectors, an important avenue for future research becomes the topic of digital transformation, a topic at the intersection between the old and the new, IT and digital, and the interface between the industrial corporation (Chandler 1962) and the networked information economy (Benkler 2006). In addition, the study focused on design as a product, while Walls et al. (1992) also point to design as a process as a key component of a design theory. Future research should extend the analysis to examine the processes of digital platform implementation and develop the process component of our nascent design theory.

Finally, the study of Weinrich et al. (2016b, paper III) may benefit from a higher degree of conceptualization and theoretical scope (Urquhart et al. 2010). In addition, the question of how to overcome the challenges that incumbents face for introducing agile methods for DBS execution may require more research.

\subsection{Research Area II: Digital Business Models}

In the FinTech business model taxonomy contribution of Eickhoff et al. (2017, paper IV), the aspiration to generality limits the granularity of both, the dimensions and characteristics developed, to fit different types of FinTechs. Thus, future research focusing on more specialized taxonomies may provide further insights. Additionally, the developed taxonomy can be used to analyze the landscape of FinTech companies more directly. For example, clustering can be performed on the characteristics assigned to each company, as opposed to the approach chosen in this paper, namely, to cluster the tags not used during taxonomy development as a confirmatory effort. Such clustering could help to identify which combinations of characteristics are 
common and show patterns across different types of business models, identifying which roles are already being filled by companies and which are not. Moreover, the taxonomy can be used to analyze companies based on other data points available on Crunchbase, such as funding success or the likelihood of long-term success or which types of investors favor particular types of FinTechs. As noted, the dynamic development of the FinTech field creates a need for future investigation. New companies may follow entirely different business models than the ones included in our dataset. Thus, future research may focus on exploring whether our taxonomy still holds. 


\section{References}

Aldushyna, A., and Engstler, M. 2015. "Erfolgsfaktoren Bei Der Umsetzung Hybrider Projekte-Ergebnisse Einer Befragung Und Praktische Empfehlungen Zur Umsetzung," Proceedings of the Gesellschaft für Informatik e.V., Lecture Notes in Informatics, Projektmanagement und Vorgehensmodelle, M. Engstler, M. Fazal-Baqaie, E. Hanser, M. Mikusz and A. Volland (eds.), Elmshorn, pp. 39-54.

Alt, R., and Puschmann, T. 2012. "The Rise of Customer-Oriented Banking Electronic Markets Are Paving the Way for Change in the Financial Industry," Electronic Markets (22:4), pp. 203-215.

Alt, R., and Zimmermann, H.-D. 2001. "Introduction to Special Section-Business Models," Electronic Markets (11:1), pp. 1019-6781.

Arner, D. W., Barberis, J. N., and Buckley, R. P. 2015. "The Evolution of Fintech: A New Post-Crisis Paradigm?," UNSW Law Research Paper No. 2016-62 (Available at SSRN 2676553), pp. 1-44.

Avizienis, A., Laprie, J.-C., Randell, B., and Landwehr, C. 2004. "Basic Concepts and Taxonomy of Dependable and Secure Computing," IEEE Transactions on Dependable and Secure Computing (1:1), pp. 11-33.

Baesens, B., Bapna, R., Marsden, J. R., Vanthienen, J., and Zhao, J. L. 2016. "Transformational Issues of Big Data and Analytics in Networked Business," MIS Quarterly (38:2), pp. 629-631.

Bajorat, A. M. 2016. "German Fintech Overview." Retrieved 11/08/2016, from http://paymentandbanking.com/german-fintech-overview-unbundling-banks/

Bakos, Y. 1998. "The Emerging Role of Electronic Marketplaces on the Internet," Communications of the ACM (41:8), pp. 35-42.

Bang, Y., Lee, D.-J., Han, K., Hwang, M., and Ahn, J.-H. 2013. "Channel Capabilities, Product Characteristics, and the Impacts of Mobile Channel Introduction," Journal of Management Information Systems (30:2), pp. 101-126.

Banker, R. D., Hu, N., Pavlou, P. A., and Luftman, J. 2011. "Cio Reporting Structure, Strategic Positioning, and Firm Performance," MIS Quarterly (35:2), pp. 487504.

Banker, R. D., and Kauffman, R. J. 2004. "50th Anniversary Article: The Evolution of Research on Information Systems: A Fiftieth-Year Survey of the Literature in Management Science," Management Science (50:3), pp. 281-298.

Baskerville, R., and Pries-Heje, J. 1999. "Grounded Action Research: A Method for Understanding It in Practice," Accounting, Management and Information Technologies (9:1), pp. 1-23.

Baskerville, R., and Pries-Heje, J. 2010. "Explanatory Design Theory," Business \& Information Systems Engineering (2:5), pp. 271-282.

Beck, K., Beedle, M., Van Bennekum, A., Cockburn, A., Cunningham, W., Fowler, M., Grenning, J., Highsmith, J., Hunt, A., and Jeffries, R. 2001. "Manifesto for Agile Software Development." Retrieved 06/30/2018, from http://agilemanifesto.org/

Benkler, Y. 2006. The Wealth of Networks: How Social Production Transforms Markets and Freedom. New Haven: Yale University Press.

Benner, M. J., and Ranganathan, R. 2012. "Offsetting Illegitimacy? How Pressures from Securities Analysts Influence Incumbents in the Face of New Technologies," Academy of Management Journal (55:1), pp. 213-233. 
Benner, M. J., and Ranganathan, R. 2013. "Divergent Reactions to Convergent Strategies: Investor Beliefs and Analyst Reactions During Technological Change," Organization Science (24:2), pp. 378-394.

Bennis, W. 2013. "Leadership in a Digital World: Embracing Transparency and Adaptive Capacity," MIS Quarterly (37:2), pp. 635-636.

Berman, S. J., Kesterson-Townes, L., Marshall, A., and Srivathsa, R. 2012a. "How Cloud Computing Enables Process and Business Model Innovation," Strategy \& Leadership (40:4), pp. 27-35.

Berman, S. J., Kesterson-Townes, L., Marshall, A., and Srivathsa, R. 2012b. "The Power of Cloud: Driving Business Model Innovation," IBM Institute for Business Value, pp. 1-18.

Bernstein, P. A., and Newcomer, E. 2009. Principles of Transaction Processing. Burlington: Morgan Kaufmann.

Besson, P., and Rowe, F. 2012. "Strategizing Information Systems-Enabled Organizational Transformation: A Transdisciplinary Review and New Directions," The Journal of Strategic Information Systems (21:2), pp. 103-124.

Bharadwaj, A., El Sawy, O. A., Pavlou, P. A., and Venkatraman, N. 2013. "Digital Business Strategy: Toward a Next Generation of Insights," MIS Quarterly (37:2), pp. 471-482.

Bhimani, A. 2015. "Exploring Big Data's Strategic Consequences," Journal of Information Technology (30:1), pp. 66-69.

Birks, D. F., Fernandez, W., Levina, N., and Nasirin, S. 2013. "Grounded Theory Method in Information Systems Research: Its Nature, Diversity and Opportunities," European Journal of Information Systems (22:1), pp. 1-8.

Boell, S. K., and Cecez-Kecmanovic, D. 2014. "On Being 'Systematic' in Literature Reviews in Is," Journal of Information Technology (30:2), pp. 161-173.

Boh, W. F., and Yellin, D. 2006. "Using Enterprise Architecture Standards in Managing Information Technology," Journal of Management Information Systems (23:3), pp. 163-207.

Bolton, R. J., and Hand, D. J. 2002. "Statistical Fraud Detection: A Review," Statistical Science (17:3), pp. 235-249.

Bonchek, M., and France, M. 2015. "The Best Digital Strategists Don't Think in Terms of Either/Or," Harvard Business Review (June 2015), pp. 1-5.

Boudreau, K. J. 2012. "Let a Thousand Flowers Bloom? An Early Look at Large Numbers of Software App Developers and Patterns of Innovation," Organization Science (23:5), pp. 1409-1427.

Briggs, R. O., Nunamaker Jr, J. F., and Sprague, R. 2011. "Applied Science Research in Information Systems: The Last Research Mile," Journal of Management Information Systems (28:1), pp. 13-16.

Buyya, R., Yeo, C. S., Venugopal, S., Broberg, J., and Brandic, I. 2009. "Cloud Computing and Emerging It Platforms: Vision, Hype, and Reality for Delivering Computing as the 5th Utility," Future Generation Computer Systems (25:6), pp. 599-616.

Carper, W. B., and Snizek, W. E. 1980. "The Nature and Types of Organizational Taxonomies: An Overview," Academy of Management Review (5:1), pp. 6575.

Carr, N. 2003. "It Doesn’t Matter," Harvard Business Review (May 2003), pp. 5-12.

Catlin, T., Patiath, P., and Segev, I. 2014. "Insurance Companies' Untapped Digital Opportunity," Harvard Business Review (March 2014), pp. 1-5.

Chandler, A. D. 1962. Strategy and Structure: The History of American Industrial Enterprise. Cambridge: MIT Press. 
Chang, R., Ziemkiewicz, C., Green, T. M., and Ribarsky, W. 2009. "Defining Insight for Visual Analytics," IEEE Computer Graphics and Applications (29:2), pp. 14-17.

Charmaz, K. 2006. Constructing Grounded Theory: A Practical Guide through Qualitative Analysis. Thousand Oaks: Sage Publications.

Chen, Y., Wang, Y., Nevo, S., Benitez, J., and Kou, G. 2017. "Improving Strategic Flexibility with Information Technologies: Insights for Firm Performance in an Emerging Economy," Journal of Information Technology (32:1), pp. 10-25.

Choobineh, J., Dhillon, G., Grimaila, M. R., and Rees, J. 2007. "Management of Information Security: Challenges and Research Directions," Communications of the Association for Information Systems (20:57), pp. 958-971.

Chow, T., and Cao, D.-B. 2008. "A Survey Study of Critical Success Factors in Agile Software Projects," Journal of Systems and Software (81:6), pp. 961-971.

Chua, W. F. 1986. "Radical Developments in Accounting Thought," Accounting Review (61:4), pp. 601-632.

Cisco. 2017. "Mobile Forecast Projects 70 Percent of Global Population Will Be Mobile Users." $\quad$ Retrieved 03/02/2017, from https://newsroom.cisco.com/press-release-content?articleId=1741352

Cohen, L., Tyler, R., Contreiras, D., and Buxton, P. 2016. "Blockchain's Three Capital Markets Innovations Explained," International Financial Law Review (35:26), pp. 9-16.

Conboy, K. 2009. "Agility from First Principles: Reconstructing the Concept of Agility in Information Systems Development," Information Systems Research (20:3), pp. 329-354.

Corbin, J., and Strauss, A. 1998. Basics of Qualitative Research: Techniques and Procedures for Developing Grounded Theory. Thousand Oaks: Sage Publications.

Cowen, D., Johnston, K. A., and Vuke, K. 2016. "How Cloud Computing Influences Business Strategy within South African Enterprises," Proceedings of the IEEE International Conference on Emerging Technologies and Innovative Business Practices for the Transformation of Societies 2016, Balaclava, Mauritius, pp. 272-278.

Crunchbase. 2016. "Crunchbase." Retrieved 03/13/2017, from http://www.crunchbase.com

Cziesla, T. 2014. "A Literature Review on Digital Transformation in the Financial Service Industry," Proceedings of the Bled eConference 2014, Bled, Slovenia, pp. 1-18.

Dapp, T., Slomka, L., AG, D. B., and Hoffmann, R. 2014. "Fintech - the Digital (R) Evolution in the Financial Sector," Deutsche Bank Research, pp. 1-39.

DaSilva, C. M., and Trkman, P. 2014. "Business Model: What It Is and What It Is Not," Long Range Planning (47:6), pp. 379-389.

Date, C. J. 2004. An Introduction to Database Systems. Boston: Addison Wesley Publishing Company.

de Reuver, M., Sørensen, C., and Basole, R. C. 2017. "The Digital Platform: A Research Agenda," Journal of Information Technology (33:2), pp. 124-135.

Delerue, H., and Vuori, M. 2012. "Exploring Uses of Social Media in a Global Corporation," Journal of Systems and Information Technology (14:2), pp. 155170.

Dewan, R. M., Freimer, M. L., and Jiang, Y. 2007. "A Temporary Monopolist: Taking Advantage of Information Transparency on the Web," Journal of Management Information Systems (24:2), pp. 167-194. 
Dingsøyr, T., Nerur, S., Balijepally, V., and Moe, N. B. 2012. "A Decade of Agile Methodologies: Towards Explaining Agile Software Development," Journal of Systems and Software (85:6), pp. 1213-1221.

Dosi, G., Nelson, R., and Winter, S. 2001. The Nature and Dynamics of Organizational Capabilities. Oxford Oxford University Press.

Drnevich, P. L., and Croson, D. C. 2013. "Information Technology and Business-Level Strategy: Toward an Integrated Theoretical Perspective," MIS Quarterly (37:2), pp. 483-509.

Eaton, B., Elaluf-Calderwood, S., Sorensen, C., and Yoo, Y. 2015. "Distributed Tuning of Boundary Resources: The Case of Apple's Ios Service System," MIS Quarterly (39:1), pp. 217-243.

Eickhoff, M., Muntermann, J., and Weinrich, T. 2017. "What Do Fintechs Actually Do? A Taxonomy of Fintech Business Models," Proceedings of the International Conference on Information Systems 2017, Seoul, South Korea, pp. 1-19.

El Sawy, O. A., Malhotra, A., Park, Y., and Pavlou, P. A. 2010. "Seeking the Configurations of Digital Ecodynamics: It Takes Three to Tango," Information Systems Research (21:4), pp. 835-848.

El Sawy, O. A., and Pereira, F. 2013. Business Modelling in the Dynamic Digital Space: An Ecosystem Approach. Springer.

Erevelles, S., Fukawa, N., and Swayne, L. 2016. "Big Data Consumer Analytics and the Transformation of Marketing," Journal of Business Research (69:2), pp. 897-904.

Favaro, K. 2016. "Don't Draft a Digital Strategy Just Because Everyone Else Is," Harvard Business Review (March 2016), pp. 1-4.

Fettke, P. 2006. "State-of-the-Art Des State-of-the-Art," Wirtschaftsinformatik (48:4), pp. 257-266.

Fichman, R. G., Dos Santos, B. L., and Zheng, Z. Q. 2014. "Digital Innovation as a Fundamental and Powerful Concept in the Information Systems Curriculum," MIS Quarterly (38:2), pp. 329-354.

FinancialTimes. 2017. "50 Journals Used in Ft Research Rank." Retrieved 11/14/2016, from https://www.ft.com/content/3405a512-5cbb-11e1-8f1f00144feabdc0

Fitzgerald, M., Kruschwitz, N., Bonnet, D., and Welch, M. 2014. "Embracing Digital Technology: A New Strategic Imperative," MIT Sloan Management Review (55:2), pp. 1-16.

Freitas Junior, J. C., Maçada, A. C., Brinkhues, R., and Montesdioca, G. 2016. "Digital Capabilities as Driver to Digital Business Performance," Proceedings of the Americas Conference on Information Systems 2016, San Diego, USA, pp. 1-5.

Galbraith, J. R. 1977. Organization Design. Boston: Addison Wesley Publishing Company.

Gawer, A. 2011. Platforms, Markets and Innovation. Cheltenham: Edward Elgar Publishing.

Ghazawneh, A., and Henfridsson, O. 2013. "Balancing Platform Control and External Contribution in Third-Party Development: The Boundary Resources Model," Information Systems Journal (23:2), pp. 173-192.

Giessmann, A., and Legner, C. 2016. "Designing Business Models for Cloud Platforms," Information Systems Journal (26:5), pp. 551-579.

Glaser, B. 1978. Theoretical Sensitivity: Advances in the Methodology of Grounded Theory. Mill Valley: Sociology Press. 
Glaser, B. 1992. Basics of Grounded Theory Analysis: Emergence Vs Forcing. Mill Valley: Sociology Press.

Glaser, B., and Strauss, A. L. 1965. Awareness of Dying. New Jersey: Transaction Publishers.

Glaser, B., Strauss, A. L., and Strutzel, E. 1968. "The Discovery of Grounded Theory; Strategies for Qualitative Research," Nursing Research (17:4), pp. 353-364.

Glass, R. L., and Vessey, I. 1995. "Contemporary Application-Domain Taxonomies," IEEE Software (12:4), pp. 63-76.

Gomber, P. 2016. "The German Equity Trading Landscape," Research Center SAFE Sustainable Architecture for Finance in Europe (No. 34. White Paper Series, 2016), pp. 1-13.

Gomber, P., Koch, J.-A., and Siering, M. 2017. "Digital Finance and Fintech: Current Research and Future Research Directions," Journal of Business Economics (forthcoming), pp. 1-44.

Gopal, C. R. 2014. Management of Financial Services. New Delhi: Vikas Publishing.

Goutas, L., Sutanto, J., and Aldarbesti, H. 2015. "The Building Blocks of a Cloud Strategy: Evidence from Three Saas Providers," Communications of the ACM (59:1), pp. 90-97.

Granados, N., and Gupta, A. 2013. "Transparency Strategy: Competing with Information in a Digital World," MIS Quarterly (37:2), pp. 637-642.

Gregor, S. 2006. "The Nature of Theory in Information Systems," Mis Quarterly (30:3), pp. 611-642.

Gregor, S., and Hevner, A. R. 2013. "Positioning and Presenting Design Science Research for Maximum Impact," MIS Quarterly (37:2), pp. 337-355.

Gregory, R. W., Keil, M., Muntermann, J., and Mahring, M. 2015. "Paradoxes and the Nature of Ambidexterity in It Transformation Programs," Information Systems Research (26:1), pp. 57-80.

Gregory, R. W., Weinrich, T., Muntermann, J., and Káganer, E. 2017. "Designing a Digital Platform for Multi-Firm Value Co-Creation," Working Paper (based on Weinrich et al. 2016), pp. 1-49.

Grover, V., and Kohli, R. 2012. "Cocreating It Value: New Capabilities and Metrics for Multifirm Environments," MIS Quarterly (36:1), pp. 225-232.

Grover, V., and Kohli, R. 2013. "Revealing Your Hand: Caveats in Implementing Digital Business Strategy," MIS Quarterly (37:2), pp. 656-662.

Guzzo, R. A., Jackson, S. E., and Katzell, R. A. 1987. "Meta-Analysis Analysis," Research in Organizational Behavior (9:1), pp. 407-442.

Haas, P., Blohm, I., and Leimeister, J. M. 2014. "An Empirical Taxonomy of Crowdfunding Intermediaries," Proceedings of the International Conference on Information Systems 2014, Auckland, New Zealand, pp. 1-18.

Haffke, I., Kalgovas, B. J., and Benlian, A. 2016. "The Role of the Cio and the Cdo in an Organization's Digital Transformation," Proceedings of the International Conference on Information Systems 2016, Dublin, Ireland, pp. 1-20.

Hansen, R., and Sia, S. K. 2015. "Hummel's Digital Transformation toward Omnichannel Retailing: Key Lessons Learned," MIS Quarterly Executive (14:2), pp. 51-66.

Hanseth, O., and Lyytinen, K. 2010. "Design Theory for Dynamic Complexity in Information Infrastructures: The Case of Building Internet," Journal of Information Technology (25:1), pp. 1-19.

Haque, U. 2015. "Your Digital Strategy Shouldn’t Be About Attention," Harvard Business Review (January 2015), pp. 1-4. 
Hart, C. W. L. 1995. "Mass Customization: Conceptual Underpinnings, Opportunities and Limits," International Journal of Service Industry Management (6:2), pp. 36-45.

Heath, H., and Cowley, S. 2004. "Developing a Grounded Theory Approach: A Comparison of Glaser and Strauss," International Journal of Nursing Studies (41:2), pp. 141-150.

Hedley, K., White, J., Petit dit de la Roche, C., and Banerjea, S. 2006. "Banking 2015: A Classic Strategy Battle of Scale Vs Focus," Strategy \& Leadership (34:3), pp. 51-58.

Henderson, J. C., and Venkatraman, H. 1993. "Strategic Alignment: Leveraging Information Technology for Transforming Organizations," IBM Systems Journal (32:1), pp. 472-484.

Henderson, J. C., and Venkatraman, N. 1992. "Strategic Alignment: A Model for Organizational Transformation through Information Technology," in Transforming Organizations, T.A. Kochan (ed.). Oxford: Oxford University Press, pp. 97-117.

Henfridsson, O., and Bygstad, B. 2013. "The Generative Mechanisms of Digital Infrastructure Evolution," MIS Quarterly (37:3), pp. 907-931.

Henfridsson, O., Mathiassen, L., and Svahn, F. 2014. "Managing Technological Change in the Digital Age: The Role of Architectural Frames," Journal of Information Technology (29:1), pp. 27-43.

Hess, T., Matt, C., Benlian, A., and Wiesböck, F. 2016. "Options for Formulating a Digital Transformation Strategy," MIS Quarterly Executive (15:2), pp. 103119.

Hevmer, A. R., March, S. T., Park, J., and Ram, S. 2004. "Design Science in Information Systems Research," MIS Quarterly (28:1), pp. 75-105.

Hirschheim, R., Klein, H. K., and Lyytinen, K. 1995. Information Systems Development and Data Modeling: Conceptual and Philosophical Foundations. Cambridge: Cambridge University Press.

Horlacher, A. 2016. "Co-Creating Value-the Dyadic Cdo-Cio Relationship During the Digital Transformation," Proceedings of the European Conference on Information Systems 2016, Istanbul, Turkey, pp. 1-11.

Huang, J. C., Henfridsson, O., Liu, M. J., and Newell, S. 2017. "Growing on Steroids: Rapidly Scaling the User Base of Digital Ventures through Digital Innovation," MIS Quarterly (41:1), pp. 301-314.

Hummel, M., Rosenkranz, C., and Holten, R. 2013. "The Role of Communication in Agile Systems Development," Business \& Information Systems Engineering (5:5), pp. 343-355.

Iivari, J. 2007. "A Paradigmatic Analysis of Information Systems as a Design Science," Scandinavian Journal of Information Systems (19:2), pp. 39-64.

Iivari, J. 2014. "Distinguishing and Contrasting Two Strategies for Design Science Research," European Journal of Information Systems (24:1), pp. 107-115.

ISO. 2010. "Systems and Software Engineering - Systems and Software Product Quality Requirements and Evaluation (Square) — Common Industry Format (Cif) for Usability: General Framework for Usability-Related Information." ISO / IEC.

Kane, G. C., Palmer, D., Phillips, A. N., Kiron, D., and Buckley, N. 2015. "Strategy, Not Technology, Drives Digital Transformation," MIT Sloan Management Review (July 2015), pp. 1-16. 
Kaniadakis, A., and Constantinides, P. 2014. "Innovating Financial Information Infrastructures: The Transition of Legacy Assets to the Securitization Market," Journal of the Association for Information Systems (15:5), pp. 244-262.

Kates, A., and Galbraith, J. R. 2010. Designing Your Organization: Using the Star Model to Solve 5 Critical Design Challenges. San Francisco: John Wiley \& Sons.

Keen, P., and Williams, R. 2013. "Value Architectures for Digital Business: Beyond the Business Model," MIS Quarterly (37:2), pp. 642-647.

Kohli, R., and Melville, N. P. 2018. "Digital Innovation: A Review and Synthesis," Information Systems Journal (forthcoming).

Kotter, J. P. 1995. "Leading Change: Why Transformation Efforts Fail," Harvard Business Review (March 1995), pp. 1-12.

Kotter, J. P. 2014. Accelerate: Building Strategic Agility for a Faster-Moving World. Boston: Harvard Business Press.

Kropp, M., and Meier, A. 2013. "Swiss Agile Study 2012," Agile SoftwareEntwicklung in der Schweiz. Zürcher Hochschule für Angewandte Wissenschaften, pp. 1-32.

Lee, D. K. C., and Teo, E. G. S. 2015. "Emergence of Fintech and the Lasic Principles," (Available at SSRN 2668049), pp. 1-17.

Lee, J., and Berente, N. 2012. "Digital Innovation and the Division of Innovative Labor: Digital Controls in the Automotive Industry," Organization Science (23:5), pp. 1428-1447.

Leischnig, A., Wölfl, S., and Ivens, B. 2016. "When Does Digital Business Strategy Matter to Market Performance?," Proceedings of the International Conference on Information Systems 2016, Dublin, Ireland, pp. 1-16.

Levy, R. 2015. "Fintech Market Map." Retrieved 02/18/2017, from https://www.mindmeister.com/de/488176466/fintech-landscape

Levy, Y., and Ellis, T. J. 2006. "A Systems Approach to Conduct an Effective Literature Review in Support of Information Systems Research," Informing Science: International Journal of an Emerging Transdiscipline (9:1), pp. 181212.

Linnæus, C. 1735. Systema Naturce, Sive Regna Tria Naturce Systematice Proposita Per Classes, Ordines, Genera, \& Species. Leiden:

Liu, J., Kauffman, R. J., and Ma, D. 2015. "Competition, Cooperation, and Regulation: Understanding the Evolution of the Mobile Payments Technology Ecosystem," Electronic Commerce Research and Applications (14:5), pp. 372-391.

Lucas Jr, H. C., Agarwal, R., Clemons, E. K., El Sawy, O. A., and Weber, B. W. 2013. "Impactful Research on Transformational Information Technology: An Opportunity to Inform New Audiences," MIS Quarterly (37:2), pp. 371-382.

Mackenzie, A. 2015. "The Fintech Revolution," London Business School Review (26:3), pp. 50-53.

Madhavan, A. 2000. "Market Microstructure: A Survey," Journal of Financial Markets (3:3), pp. 205-258.

Marchant, G. E. 2011. "The Growing Gap between Emerging Technologies and the Law," in The Growing Gap between Emerging Technologies and Legal-Ethical Oversight: The Pacing Problem, G.E. Marchant, B.R. Allenby and J.R. Herkert (eds.). Electronic: Springer Publishing, pp. 19-33.

Markus, M. L., and Loebbecke, C. 2013. "Commoditized Digital Processes and Business Community Platforms: New Opportunities and Challenges for Digital Business Strategies," MIS Quarterly (37:2), pp. 649-654. 
Matavire, R., and Brown, I. 2013. "Profiling Grounded Theory Approaches in Information Systems Research," European Journal of Information Systems (22:1), pp. 119-129.

Matt, C., Hess, T., and Benlian, A. 2015. "Digital Transformation Strategies," Business \& Information Systems Engineering (57:5), pp. 339-343.

McGrath, R. 2013. "The Pace of Technology Adoption Is Speeding Up." Retrieved 01/22/2017, from https://hbr.org/2013/11/the-pace-of-technology-adoption-isspeeding-up

Mingers, J. 2001. "Combining Is Research Methods: Towards a Pluralist Methodology," Information Systems Research (12:3), pp. 240-259.

Mithas, S., Agarwal, R., and Courtney, H. 2012. "Digital Business Strategies and the Duality of It," IEEE IT Professional (14:5), pp. 2-4.

Mithas, S., and Lucas, H. C. 2010. "What Is Your Digital Business Strategy?," IEEE IT Professional (12:6), pp. 4-6.

Mithas, S., Tafti, A., and Mitchell, W. 2013. "How a Firm's Competitive Environment and Digital Strategic Posture Influence Digital Business Strategy," MIS Quarterly (37:2), pp. 511-536.

Moore, G. E. 1965. "Cramming More Components onto Integrated Circuits," Electronics (38:8), pp. 1-4.

Morton, M. S. S. 1971. Management Decision Systems: Computer-Based Support of Decision Making. Boston: Harvard University Press.

Nerur, S., Mahapatra, R., and Mangalaraj, G. 2005. "Challenges of Migrating to Agile Methodologies," Communications of the ACM (48:5), pp. 72-78.

New, S. 2010. "The Transparent Supply Chain," Harvard Business Review (October 2010), pp. 1-5.

Nickerson, R. C., Varshney, U., and Muntermann, J. 2013. "A Method for Taxonomy Development and Its Application in Information Systems," European Journal of Information Systems (22:3), pp. 336-359.

OECD Directorate for Financial and Enterprise Affairs. 2005. "Recommendation on Principles and Good Practices for Financial Education and Awareness."

Oestreicher-Singer, G., and Zalmanson, L. 2013. "Content or Community? A Digital Business Strategy for Content Providers in the Social Age," MIS Quarterly (37:2), pp. 591-616.

Orlikowski, W. J., and Baroudi, J. J. 1991. "Studying Information Technology in Organizations: Research Approaches and Assumptions," Information Systems Research (2:1), pp. 1-28.

Osterwalder, A., and Pigneur, Y. 2002. "An E-Business Model Ontology for Modeling Ebusiness," Proceedings of the Bled eConference 2002, pp. 1-12.

Osterwalder, A., and Pigneur, Y. 2010. Business Model Generation: A Handbook for Visionaries, Game Changers, and Challengers. San Francisco: John Wiley \& Sons.

Osterwalder, A., Pigneur, Y., and Tucci, C. L. 2005. "Clarifying Business Models: Origins, Present, and Future of the Concept," Communications of the Association for Information Systems (16:1), pp. 1-27.

Oxford-Dictionaries. 2016. "Oxford Living Dictionary." Retrieved 02/19/2017, from https://en.oxforddictionaries.com

Pagani, M. 2013. "Digital Business Strategy and Value Creation: Framing the Dynamic Cycle of Control Points," MIS Quarterly (37:2), pp. 617-632.

Palekar, S., and Sedera, D. 2015. "Destabilizing Digital Business Strategy through Competing-Complementarity of Social Media," Proceedings of the Pacific Asia Conference on Information Systems 2015, Singapore, pp. 1-17. 
Parasuraman, R., and Riley, V. 1997. "Humans and Automation: Use, Misuse, Disuse, Abuse," Human Factors: The Journal of the Human Factors and Ergonomics Society (39:2), pp. 230-253.

Parasuraman, R., Sheridan, T. B., and Wickens, C. D. 2000. "A Model for Types and Levels of Human Interaction with Automation," IEEE Transactions on systems, man, and cybernetics-Part A: Systems and Humans (30:3), pp. 286297.

Paré, G., Trudel, M.-C., Jaana, M., and Kitsiou, S. 2015. "Synthesizing Information Systems Knowledge: A Typology of Literature Reviews," Information \& Management (52:2), pp. 183-199.

Parker, G. G., Van Alstyne, M. W., and Choudary, S. P. 2016. Platform Revolution: How Networked Markets Are Transforming the Economy--and How to Make Them Work for You. New York: W. W. Norton \& Company.

Patnayakuni, R., and Patnayakuni, N. 2014. "Information Security in Value Chains: A Governance Perspective," Proceedings of the Americas Conference on Information Systems 2014, Savannah, USA, pp. 1-10.

Pine, B. J., Victor, B., and Boynton, A. C. 1993. "Making Mass Customization Work," Harvard Business Review (January 1993), pp. 1-10.

Power, D. J. 2004. "Specifying an Expanded Framework for Classifying and Describingdecision Support Systems," Communications of the Association for Information Systems (13:1), pp. 158-167.

Prat, N., Comyn-Wattiau, I., and Akoka, J. 2015. "A Taxonomy of Evaluation Methods for Information Systems Artifacts," Journal of Management Information Systems (32:3), pp. 229-267.

Priem, R. L., Butler, J. E., and Li, S. 2013. "Toward Reimagining Strategy Research: Retrospection and Prospection on the 2011 Amr Decade Award Article," Academy of Management Review (38:4), pp. 471-489.

Puschmann, T. 2017. "Fintech," Business \& Information Systems Engineering (59:1), pp. 69-76.

Remane, G., Hanelt, A., Nickerson, R. C., and Kolbe, L. M. 2017. "Discovering Digital Business Models in Traditional Industries," Journal of Business Strategy (38:2), pp. 41-51.

Resnick, P., and Varian, H. R. 1997. "Recommender Systems," Communications of the ACM (40:3), pp. 56-58.

Reuters, T. 2016. "Financial Glossary." Retrieved 04/16/2017, from http://glossary.reuters.com/

Richardson, G. L., Jackson, B. M., and Dickson, G. W. 1990. "A Principles-Based Enterprise Architecture: Lessons from Texaco and Star Enterprise," MIS Quarterly (14:4), pp. 385-403.

Richardson, J. 2008. "The Business Model: An Integrative Framework for Strategy Execution," Strategic Change (17:5-6), pp. 133-144.

Romanelli, E., and Tushman, M. L. 1994. "Organizational Transformation as Punctuated Equilibrium: An Empirical Test," Academy of Management Journal (37:5), pp. 1141-1166.

Ross, J. W., Beath, C. M., and Sebastian, I. 2015. "Why Nordstrom’s Digital Strategy Works (and Yours Probably Doesn't)," Harvard Business Review (January 2015), pp. 1-4.

Ross, J. W., Sebastian, I. M., Beath, C., Mocker, M., Fondstad, N. O., and Moloney, K. G. 2016. "Designing and Executing Digital Strategies," Proceedings of the International Conference on Information Systems 2016, Dublin, Ireland, pp. 117. 
Ross, J. W., Weill, P., and Robertson, D. C. 2006. Enterprise Architecture as Strategy: Creating a Foundation for Business Execution. Boston: Harvard Business Press.

Ruch, T. J., and Gregory, R. W. 2014. "Consumerization of It - Where Is the Theory?," Proceedings of the Pacific Asia Conference on Information Systems 2014, Chengdu, China, pp. 1-17.

Rycroft, R. W. 2006. "Time and Technological Innovation: Implications for Public Policy," Technology in Society (28:3), pp. 281-301.

Schmidt, C., and Buxmann, P. 2011. "Outcomes and Success Factors of Enterprise It Architecture Management: Empirical Insight from the International Financial Services Industry," European Journal of Information Systems (20:2), pp. 168185.

Selander, L., Henfridsson, O., and Svahn, F. 2013. "Capability Search and Redeem across Digital Ecosystems," Journal of Information Technology (28:3), pp. 183-197.

Setia, P., Venkatesh, V., and Joglekar, S. 2013. "Leveraging Digital Technologies: How Information Quality Leads to Localized Capabilities and Customer Service Performance," MIS Quarterly (37:2), pp. 565-590.

Shimodaira, H. 2004. "Approximately Unbiased Tests of Regions Using MultistepMultiscale Bootstrap Resampling," Annals of Statistics (32:6), pp. 2616-2641.

Sia, S. K., Soh, C., and Weill, P. 2016. "How Dbs Bank Pursued a Digital Business Strategy," MIS Quarterly Executive (15:2), pp. 105-121.

Sinanaj, G., Cziesla, T., Kemper, J., and Muntermann, J. 2015a. "Nsa Revelations of Privacy Breaches: Do Investors Care?," Proceedings of the Americas Conference on Information Systems 2015, Fajardo, Puerto Rico, pp. 1-12.

Sinanaj, G., Muntermann, J., and Cziesla, T. 2015b. "How Data Breaches Ruin Firm Reputation on Social Media!-Insights from a Sentiment-Based Event Study," Proceedings of the Wirtschaftsinformatik 2015, Osnabrück, Germany, pp. 902916.

Sircar, S., Nerur, S. P., and Mahapatra, R. 2001. "Revolution or Evolution? A Comparison of Object-Oriented and Structured Systems Development Methods," MIS Quarterly (25:4), pp. 457-471.

Spulber, D. F. 1996. "Market Microstructure and Intermediation," The Journal of Economic Perspectives (10:3), pp. 135-152.

Strauss, A., and Corbin, J. 1990. Basics of Qualitative Research: Techniques and Procedures for Developing Grounded Theory. Thousand Oaks: Sage Publications.

Suzuki, R., and Shimodaira, H. 2006. "Pvclust: An R Package for Assessing the Uncertainty in Hierarchical Clustering," Bioinformatics (22:12), pp. 15401542.

Svahn, F., Mathiassen, L., and Lindgren, R. 2017. "Embracing Digital Innovation in Incumbent Firms: How Volvo Cars Managed Competing Concerns," MIS Quarterly (41:1), pp. 239-253.

Tamm, T., Seddon, P. B., Shanks, G. G., and Reynolds, P. 2011. "How Does Enterprise Architecture Add Value to Organisations?," Communications of the Association of Information Systems (28:1), pp. 141-168.

Tan, C. W., Benbasat, I., and Cenfetelli, R. T. 2016. "An Exploratory Study of the Formation and Impact of Electronic Service Failures," MIS Quarterly (40:1), pp. 1-29.

Teece, D. J. 2010. "Business Models, Business Strategy and Innovation," Long Range Planning (43:2), pp. 172-194. 
Templier, M., and Paré, G. 2015. "A Framework for Guiding and Evaluating Literature Reviews," Communications of the Association for Information Systems (37:1), pp. 112-137.

Tilson, D., Lyytinen, K., and Sørensen, C. 2010. "Research Commentary - Digital Infrastructures: The Missing Is Research Agenda," Information Systems Research (21:4), pp. 748-759.

Tiwana, A., and Kim, S. K. 2015. "Discriminating It Governance," Information Systems Research (26:4), pp. 656-674.

Tiwana, A., Konsynski, B., and Bush, A. A. 2010. "Platform Evolution: Coevolution of Platform Architecture, Governance, and Environmental Dynamics," Information Systems Research (21:4), pp. 675-687.

Todorov, D. 2007. Mechanics of User Identification and Authentication: Fundamentals of Identity Management. Boca Raton: Auerbach Publications.

Urquhart, C. 2002. "Regrounding Grounded Theory-or Reinforcing Old Prejudices? A Brief Reply to Bryant," Journal of Information Technology Theory and Application (4:3), pp. 43-54.

Urquhart, C. 2007. The Sage Handbook of Grounded Theory. Thousand Oaks: Sage Publications.

Urquhart, C. 2012. Grounded Theory for Qualitative Research: A Practical Guide. Thousand Oaks: Sage Publications.

Urquhart, C., Lehmann, H., and Myers, M. D. 2010. "Putting the 'Theory’ Back into Grounded Theory: Guidelines for Grounded Theory Studies in Information Systems," Information Systems Journal (20:4), pp. 357-381.

Valentine, E., and Stewart, G. 2015. "Enterprise Business Technology Governance: Three Competencies to Build Board Digital Leadership Capability," Proceedings of the Hawaii International Conference on System Sciences 2015, Kauai, USA, pp. 4513-4522.

Van de Ven, A. H. 2007. Engaged Scholarship: A Guide for Organizational and Social Research. Oxford: Oxford University Press.

Varshney, U., Nickerson, R., and Muntermann, J. 2015. "Towards the Development of a Taxonomic Theory," Proceedings of the American Conference of Information Systems 2015, Fajardo, Puerto Rico, pp. 1-15.

Veit, D., Clemons, E., Benlian, A., Buxmann, P., Hess, T., Kundisch, D., Leimeister, J. M., Loos, P., and Spann, M. 2014. "Business Models," Business \& Information Systems Engineering (6:1), pp. 45-53.

Venkatraman, N. 1994. "It-Enabled Business Transformation: From Automation to Business Scope Redefinition," Sloan Management Review (35:2), pp. 73-87.

Walls, J. G., Widmeyer, G. R., and El Sawy, O. A. 1992. "Building an Information System Design Theory for Vigilant Eis," Information Systems Research (3:1), pp. 36-59.

Walsham, G. 1993. Interpreting Information Systems in Organizations. San Francisco: John Wiley \& Sons.

Wand, Y., Monarchi, D. E., Parsons, J., and Woo, C. C. 1995. "Theoretical Foundations for Conceptual Modelling in Information Systems Development," Decision Support Systems (15:4), pp. 285-304.

Wareham, J., Fox, P. B., and Cano Giner, J. L. 2014. "Technology Ecosystem Governance," Organization Science (25:4), pp. 1195-1215.

Watson, H. J., Wixom, B. H., Hoffer, J. A., Anderson-Lehman, R., and Reynolds, A. M. 2006. "Real-Time Business Intelligence: Best Practices at Continental Airlines," Information Systems Management (23:1), pp. 7-18. 
Webster, J., and Watson, R. T. 2002. "Analyzing the Past to Prepare for the Future: Writing a Literature Review," MIS Quarterly (26:2), pp. xiii-xxiii.

Weill, P., and Ross, J. W. 2009. It Savvy: What Top Executives Must Know to Go from Pain to Gain. Boston: Harvard Business Press.

Weinrich, T. 2017. "Reviewing Organizational Design Components for Digital Business Strategy," Proceedings of the Bled eConference 2017, Bled, Slovenia, pp. 1-18.

Weinrich, T., Muntermann, J., and Gregory, R. W. 2016a. "Exploring Principles for Corporate Digital Infrastructure Design in the Financial Services Industry," Proceedings of the Pacific Asia Conference on Information Systems 2016, Chiayi,Taiwan, pp. 1-15.

Weinrich, T., Volland, A., and Muntermann, J. 2016b. "Herausforderungen Bei Der Einführung Agiler Vorgehensmodelle Für Finanzdienstleister-Eine Fallstudie," Proceedings of the Gesellschaft für Informatik e.V., Lecture Notes in Informatics, Projektmanagement und Vorgehensmodelle 2016, M. Engstler, M. Fazal-Baqaie, E. Hanser, O. Linssen, M. Mikusz and A. Volland (eds.), Paderborn, Germany, pp. 79-91.

Wenzel, M., Wagner, D., Wagner, H.-T., and Koch, J. 2015. "Digitization and Path Disruption: An Examination in the Funeral Industry," Proceedings of the European Conference on Information Systems 2015, Münster, Germany, pp. 118.

Wiesche, M., Jurisch, M. C., Yetton, P. W., and Krcmar, H. 2017. "Grounded Theory Methodology in Information Systems Research," MIS Quarterly (41:3), pp. 685-701.

Woerner, S., and Wixom, B. H. 2015. "Big Data: Extending the Business Strategy Toolbox," Journal of Information Technology (30:1), pp. 60-62.

Wolfswinkel, J. F., Furtmueller, E., and Wilderom, C. P. 2013. "Using Grounded Theory as a Method for Rigorously Reviewing Literature," European Journal of Information Systems (22:1), pp. 45-55.

Woodard, C. J., Ramasubbu, N., Tschang, F. T., and Sambamurthy, V. 2013. "Design Capital and Design Moves: The Logic of Digital Business Strategy," MIS Quarterly (37:2), pp. 537-564.

Xue, L., Ray, G., and Sambamurthy, V. 2012. "Efficiency or Innovation: How Do Industry Environments Moderate the Effects of Firms' It Asset Portfolios," MIS Quarterly (36:2), pp. 509-528.

Xue, Y., Liang, H., and Boulton, W. R. 2008. "Information Technology Governance in Information Technology Investment Decision Processes: The Impact of Investment Characteristics, External Environment, and Internal Context," MIS Quarterly (32:1), pp. 67-96.

Yin, R. K. 2013. Case Study Research: Design and Methods. Thousand Oaks: Sage Publications.

Yoo, Y. 2010. "Computing in Everyday Life: A Call for Research on Experiential Computing," MIS Quarterly (34:2), pp. 213-231.

Yoo, Y., Boland Jr, R. J., Lyytinen, K., and Majchrzak, A. 2012. "Organizing for Innovation in the Digitized World," Organization Science (23:5), pp. 13981408.

Yoo, Y., Henfridsson, O., and Lyytinen, K. 2010. "Research Commentary - the New Organizing Logic of Digital Innovation: An Agenda for Information Systems Research," Information Systems Research (21:4), pp. 724-735.

Zachman, J. A. 1987. "A Framework for Information Systems Architecture," IBM Systems Journal (26:3), pp. 276-292. 
Zott, C., Amit, R., and Massa, L. 2011. "The Business Model: Recent Developments and Future Research," Journal of Management (37:4), pp. 1019-1042. 


\section{Appendix}


Overview of studies and author contribution ratios

\begin{tabular}{|c|c|c|c|c|}
\hline & No. & Title (Citation) & Author(s) & Contributions \\
\hline \multirow{11}{*}{ 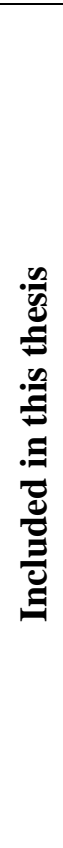 } & 1 & $\begin{array}{l}\text { Reviewing Organizational Design Components } \\
\text { for Digital Business Strategy (Weinrich 2017) }\end{array}$ & Weinrich & $100 \%$ \\
\hline & \multirow[t]{4}{*}{2} & Designing a Digital Platform for Multi-Firm & Gregory & $35 \%$ \\
\hline & & Value Co-Creation (Gregory et al. 2017) & Weinrich & $30 \%$ \\
\hline & & & Muntermann & $25 \%$ \\
\hline & & & Káganer & $10 \%$ \\
\hline & \multirow[t]{3}{*}{3} & Herausforderungen für die Einführung agiler & Weinrich & $90 \%$ \\
\hline & & Vorgehensmodelle (Weinrich et al. 2016b) & Muntermann & $5 \%$ \\
\hline & & & Volland & $5 \%$ \\
\hline & \multirow[t]{3}{*}{4} & What do FinTechs actually do? A Taxonomy of & Eickhoff & $33,3 \%$ \\
\hline & & FinTech Business Models (Eickhoff et al. 2017) & Muntermann & $33,3 \%$ \\
\hline & & & Weinrich & $33,3 \%$ \\
\hline \multirow{9}{*}{ 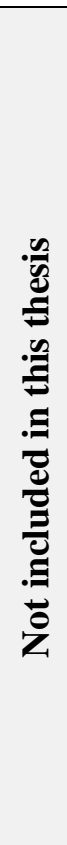 } & 5 & $\begin{array}{l}\text { Exploring principles for corporate digital } \\
\text { infrastructure design in the financial services } \\
\text { industry (Weinrich et al. 2016a) }\end{array}$ & $\begin{array}{l}\text { Weinrich } \\
\text { Muntermann } \\
\text { Gregory }\end{array}$ & \\
\hline & \multirow[t]{4}{*}{6} & NSA Revelations of Privacy Breaches: Do & Sinanaj & \\
\hline & & Investors Care? (Sinanaj et al. 2015a) & Cziesla & \\
\hline & & & Kemper & \\
\hline & & & Muntermann & \\
\hline & \multirow[t]{3}{*}{7} & How Data Breaches Ruin Firm Reputation on & Sinanaj & \\
\hline & & Social Media! - Insights from a Sentiment-based & Muntermann & \\
\hline & & Event Study (Sinanaj et al. 2015b) & Cziesla & \\
\hline & 8 & $\begin{array}{l}\text { A Literature Review on Digital Transformation } \\
\text { in the Financial Service Industry (Cziesla 2014) }\end{array}$ & Cziesla & \\
\hline
\end{tabular}

